\title{
LO AFRO Y LA PLURINACIONALIDAD \\ El caso ecuatoriano visto desde su literatura
}



Michael Handelsman

\section{LO AFRO Y LA PLURINACIONALIDAD \\ El caso ecuatoriano visto desde su literatura}

Reedición para Ecuador de Romance Monographs No 54 University, Mississippi

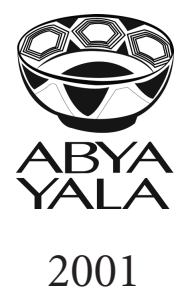


LO AFRO Y LA PLURINACIONALIDAD

El caso ecuatoriano visto desde su literatura

Michael Handelsman

1ra. Edición en Romance Monographs No 54

Estados Unidos: University, Mississippi, 1999

ISBN-1-889441-04-X

1ra. Edición Ediciones Abya-Yala

en Ecuador: $\quad$ Av. 12 de octubre 14-30 y Wilson

Telfs.: 562-633 / 506-267

Fax: 506-255 / 506-267

Casilla 17-12-719

E-mail: editorial@abyayala.org

www.abyayala.org

Quito-Ecuador

ISBN 978-9978-04-688-3

Autoedición: Ediciones Abya-Yala

Quito-Ecuador

Impresión: Producciones digitales Abya-Yala

Quito-Ecuador

Impreso en Quito-Ecuador, junio de 2001 


\section{Nota preliminar}

Este libro no hubiera sido posible sin el apoyo y colaboración de muchos amigos, colegas y estudiantes que han tenido la paciencia y buena voluntad de compartir conmigo sus ideas y conocimientos acerca de lo afro, la plurinacionalidad y lo ecuatoriano. La Universidad de Tennessee ha sido constante con su apoyo financiero que me ha permitido realizar mis investigaciones en el Ecuador y publicar este volumen con Romance Monographs. En particular, estoy sumamente agradecido por mi semestre con licencia en la primavera de 1998 y por el auspicio del fondo universitario de SARIF EPPE.

Quisiera reconocer la gentileza de los directores de las Editoriales Abrapalabra y El Conejo del Ecuador; también, la de los directores de las siguientes revistas académicas: Afro-Hispanic Review, Revista de Estudios Colombianos y Latinoamericanos y Chasqui. Estos colegas me concedieron el permiso para reproducir materiales que se habían publicado anteriormente y cuyos datos constan en las notas bibliográficas del presente volumen.

Un agradecimiento muy especial le debo al amigo Humberto Robles, manabita y profesor de Northwestern University. También, quisiera mandar abrazos a Rafael Hernández, Richard Jackson, David William Foster, Raúl Vallejo, Greg Kaplan, Nelson Estupiñán Bass, Argentina Chiriboga, Luis Zúñiga, Buddy Arrington y Otto Suárez. Finalmente, he de constatar que sin la presencia de mi esposa, Toya, e hijas, Leah y Alysa, nada tendría mucho sentido. 



\section{Indice}

Introducción.

\section{Capitulo I}

I. La literatura afroecuatoriana en el contexto nacional:

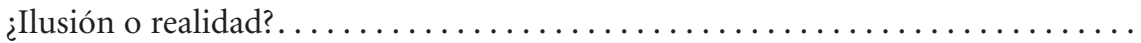

II. Personajes negros y realismo social: el caso del grupo de Guayaquil . . . . . . . . 25

III. Recuperando una canción dos veces perdida: una análisis afrocéntrico de tambores para una canción perdida de Jorge Velasco Mackenzie

IV. Lo afro, la costa y la plurinacionalidad del Ecuador:

Un tríptico visto a partir de viajando por pueblos costeños de Jorge Martillo .....

\section{Capitulo II}

V. Las contradicciones ineludibles del "no-racismo" ecuatoriano:

A propósito de Juyungo como artefacto de la diaspora afroamericana ..........

VI. Jonatas y Manuela: Lo afroecuatoriano como discurso alternativo de lo nacional y lo andino

VII. Del mestizaje al "proceso de comunidades negras":

Reflexiones sobre la evolución de una política afrocéntrica en el Ecuador ...

Coda final

Obras citadas 



\section{Introducción}

La plurinacionalidad como expresión de la transculturación

Uno de los temas más candentes de discusión en el Ecuador del fin del milenio es el de la plurinacionalidad. Impulsado primordialmente por diversos grupos indígenas que se han autodeclarado como nacionalidades, el tema de la plurinacionalidad ha puesto en jaque el paradigma tradicional de la nacionalidad ecuatoriana cuyas raíces se encuentran en el siglo XIX. En un artículo intitulado, "El debate sobre la plurinacionalidad aún no concluye," publicado en el El Universo de Guayaquil (31 mayo 98; 6-7), se vislumbran la conflictividad y la intensidad de dicho debate. Por un lado, Nina Pacari, dirigente de "La Confederación de Nacionalidades Indígenas del Ecuador," ve en la nueva constitución elaborada y propuesta por la Asamblea Nacional de 1998 un "momento de considerar a los indígenas como actores en el proceso de un desarrollo autogestionario, 'sin plantear la caridad ni la mendicidad'" (6). Por otro lado, en cambio, Fabián Corral, Decano de la Facultad de Leyes de la Universidad San Francisco de Quito, lamenta que las reformas propuestas, "al establecer ciertos principios constitucionales, $[\ldots$ hayan generado] ciertos conceptos [que] se 'anclaron' en una Constitución que no refleja el carácter cambiante de la sociedad ni el rápido proceso de aculturación por el que atraviesan los pueblos indígenas. Más aún [según el reportaje], Corral teme que la Carta Política no refleje la predominancia mestiza en una sociedad tan compleja como la ecuatoriana, donde 'ni siquiera el poncho es indígena, si no mestizo"' (6).

Los sentimientos de Corral recogidos en el artículo periodístico que se acaba de citar revelan algunos equívocos que no pocos ecuatorianos manejan al expresar su oposición a la temida plurinacionalidad. Concretamente, la referencia a la supuesta "aculturación" de los indios sugiere un abandono de vivencias propias mientras que el mestizaje se entiende como un gran crisol cultural en el cual las herencias particulares de algunos grupos que han dado forma al Ecuador desaparecen o, por lo menos, dejan de ser percibidas como componentes constituyentes del país. De ahí la imagen del poncho mestizo, símbolo de "una sociedad tan compleja como la ecuatoriana," que paradójicamente, ha perdido su rica historia evolutiva en un mestizaje genérico que ya no reconoce sus múltiples identidades.

Conviene recordar aquí a Fernando Ortiz, pensador cubano y autor de Contrapunteo cubano del tabaco y el azúcar, quien en 1940 explicó que la cultura sincrética de Cuba (y, por extensión, las de 
América Latina, en general) fue el producto de la transculturación más que de una aculturación. En su introducción al libro de Ortiz, el antropólogo Bronislaw Malinowski celebró lo genial del nuevo concepto creado por el colega cubano, y puntualizó:

Un proceso en el cual emerge una nueva realidad, compuesta y compleja; una realidad que no es una aglomeración mecánica de caracteres, ni siquiera un mosaico, sino un fenómeno nuevo, original e independiente. [... La] transculturación proporciona

un término que no contiene la implicación de una cierta cultura hacia la cual tiene que tender la otra [i.e., la aculturación], sino una transición entre dos culturas, ambas activas, ambas contribuyentes con sendos aportes, y ambas cooperantes al advenimiento de una nueva realidad de civilización. (xxxiii) ${ }^{1}$

En efecto, si se entiende el mestizaje en los términos empleados por Ortiz, el poncho al que ha aludido Corral no tiene por qué perder su identidad indígena ya que la interacción cultural es constante, protéica y mutua. Pertinente a esta discusión es la perspectiva del crítico peruano, Antonio Cornejo Polar, quien ha razonado en uno de sus estudios acerca del narrador ejemplar, José María Arguedas:

En el indio moderno-pensaba Arguedas-casi no hay rastros del pasado prehispánico, pero lo que se le ha impuesto desde fuera y lo que más o menos libremente ha asumido de otras tradiciones resulta radicalmente transformado en tér- minos de uso y de sentido hasta un punto tal que su identidad moderna - pese y tal vez gracias a esos cambios-sigue siendo inconfundiblemente indígena. ("Condición migrante e intertextualidad multicultural..."101)

Indudablemente, la plurinacionalidad-por lo menos, como la maneja Pacari en la referencia citada en El Universo- puede interpretarse como una nueva manifestación de la transculturación. Es decir, la plurinacionalidad pretende reafirmar y reactivar el rol protagónico de todos los miembros de la familia ecuatoriana. Volviendo a Cornejo Polar, no es una casualidad que él haya puesto de relieve la relación entre el mestizaje y la transculturación:

[...] no intento formular una dicotomía entre mestizo y migrante, y entre sus respectivos lenguajes e inserciones intertextuales, sino establecer dos posiciones de enunciación, que a veces pueden y deben articularse. En todo caso, por el momento, me entusiasma la idea de cruzar de ida y vuelta el paradigma del mestizo y la transculturación, y su modelo en última instancia sincrético, de una parte, con la movediza sintaxis del migrante y su multicultura fragmentaria, de otra. Tal vez sólo con ambas perspectivas-que por cierto no excluyen otras-nos será posible dar razón de la trama de una literatura enredada, de un vasto y escurridizo discurso, de una cultura que prolifera en variantes, de un universo plural y pluralizante cuyo único orden quizás no sea otro que el caos de una creación (igozosamente?) incompleta. ("Condición migrante e intertextualidad multicultural..." 108) 
Las referencias al migrante en combinación con el mestizaje y la transculturación resultan profundamente sugerentes al reflexionar sobre la plurinacionalidad ecuatoriana, un conjunto de culturas en constante movimiento. De hecho, el historiador ecuatoriano, Jorge Salvador Lara, ha constatado que "el Ecuador ha sido no sólo en la prehistoria encrucijada de migraciones y tendencias: también lo ha sido durante toda la historia" (Breve historia contemporánea del Ecuador 14). Más adelante, Lara siguió elaborando su retrato de un Ecuador dinámico y pluralista: “[...] vivir a horcajadas sobre la línea equinoccial, recibir el pleno sol de la mitad del mundo, mirar y pisar los dos hemisferios a la vez-el austral y el boreal-, contemplar constelaciones antípodas que sólo desde aquí se pueden ver simultáneamente [...]; estar, en fin, abiertos a todos los vientos del planeta" (16-17).

\section{Lo afro como componente medular de la plurinacionalidad ecuatoriana}

La simultaneidad de las diversas culturas y herencias del país tan bellamente expresada por Jorge Salvador Lara resulta ser una invitación a superar conceptos esencialistas de la(s) identidad(es) nacional(es) y, además, de un mestizaje nacional/latinoamericano amorfo y amnésico. De ahí viene a la mente la analogía (y la necesidad) de captar el bosque a través de sus árboles. Es precisamente en este contexto múltiple y plurinacional que ofrezco Lo afro y la plurinacionalidad: el caso ecuatoriano visto desde su literatura.
Aunque hay la tendencia de tratar el proyecto plurinacional casi exclusivamente en términos de los reclamos articulados por los indígenas, es esencial anotar que si dicho proyecto va a conducir a una nueva concepción y a una amplia aceptación de la heterogeneidad del país, urge reconocer plenamente la presencia afro en todo discurso plurinacional, especialmente en lo que respecta a la evolución dinámica de la Costa ecuatoriana, o retomando la imagen de Fernando Ortiz, al contrapunteo ecuatoriano de la Costa y la Sierra.

Si bien es cierto que la diáspora afroamericana llegó hace más de 500 años al Ecuador envuelta en y empujada por uno de aquellos "vientos del planeta" destacados arriba, es también cierto que la presencia afroecuatoriana ha sido marginada del imaginario nacional y andino ya que se la ha considerado erróneamente como ancilar o exótica-como una cultura desplazada del Caribe. En este libro, defiendo su centralidad respecto a lo ecuatoriano y, por extensión, a lo andino, convencido de que será posible forjar un destino común sólo a partir de todas las diferencias, un planteamiento apasionadamente discutido en todo el mundo actual. ${ }^{2}$ Por consiguiente, más que la fragmentación o la desunión, un acercamiento afrocéntrico a lo ecuatoriano ha de contribuir a la construcción de un Ecuador más democrático y plurinacional con la capacidad y la voluntad de comprender, respetar y celebrar la valía y la heterogeneidad cultural de todos sus ciudadanos. 
A diferencia de otros proyectos culturales y/o políticos que han sido elaborados a partir de una supuesta amalgama de las diversidades nacionales y que constituyen una expresión propia de la aculturación en vez de la transculturación, la plurinacionalidad no pretende evitar (negar) los conflictos y las tensiones que seguirán marcando las relaciones entre grupos distintos que viven renegociando y redefiniendo continuamente dichas relaciones, según el momento y las circunstancias en que se hallan. Esta fluidez de intereses, propósitos y comportamientos sigue siendo una de las principales características de la experiencia afroecuatoriana en un país (en una región) donde se ha definido lo nacional/andino exclusivamente en términos tripartitas: los blancos, los mestizos y los indios. Por eso, no extraña encontrar en el reportaje sobre la plurinacionalidad ya citado de El Universo que representantes afroecuatorianos hayan expresado su inconformidad "con las reformas hechas en la Asamblea, ya que argumentan que no se trató los derechos del pueblo negro por separado" (6). Más concretamente, Oscar Chalá, antropólogo de la comunidad negra del Chota, puntualizó: "No queremos ser añadidura de nadie ni que la sociedad ecuatoriana en su conjunto quiera mirarnos a través del espejo organizativo del pueblo indígena" (7).

Parece evidente que el debate sobre la plurinacionalidad está abriendo un espacio nuevo desde el cual se puede adelantar una revaloración de lo afro, lo ecuatoriano y lo andino en todos los campos académicos y no-académicos. Al volver a la literatura con una nueva óptica, una anclada en el afrocentrismo, por ejemplo, se descubre la medida en que los esfuerzos reivindicativos de un escritor como Nelson Estupiñán Bass del Ecuador (y Manuel Zapata Olivella de Colombia o Nicomedes Santa Cruz del Perú, entre muchos otros), siempre apuntaban en el fondo a un Ecuador (léanse, también, Colombia y Perú) que consistía tanto de la marimba como de la flauta andina. En efecto, el afrocentrismo como método crítico, tanto en los estudios literarios como en cualquier otro campo, revela que el interés en resaltar lo afro trasciende separatismos ya que complementa las vivencias que siguen formando el conjunto plurinacional del Ecuador. Respecto a esta perspectiva comprehensiva de lo afro y su relación con lo plurinacional, conviene recordar de nuevo a Fernando Ortiz, quien explicó en su Contrapunteo cubano del tabaco y el azúcar.

Hemos escogido el vocablo transculturación para expresar los variadísimos fenómenos que se originan en Cuba por las complejísimas transmutaciones de culturas que aquí se verifican, sin conocer las cuales es imposible entender la evolución del pueblo cubano, así en lo económico como en lo institucional, jurídico, ético, religioso, artístico, lingüístico, psicológico, sexual y en los demás aspectos de su vida. (86)

Puesto que la revaloración elaborada en el presente libro arranca, de una manera u otra, del concepto de la transcultu- 
ración de Ortiz (y de conceptos posteriores como los de la hibridez y el multiculturalismo), lo afro y lo ecuatoriano se proyectan aquí como lo afroecuatoriano-es decir, íntimamente unidos e igualmente visibles, pero sin ser opacados o absorbidos lo uno por lo otro. ${ }^{3}$

Si bien es cierto que los textos analizados a continuación revelan la historia conflictiva, y todavía elusiva, de la plurinacionalidad ecuatoriana, por lo menos en términos de una identidad ampliamente aceptada e internalizada, es también cierto que se prestan a lecturas liberadoras puesto que dejan al descubierto ciertas fisuras en las maneras tradicionales de pensar/conceptualizar/jerarquizar las relaciones entre los ecuatorianos. A veces, dichas fisuras surgen de una escritura de protesta, abierta u oblicuamente expresada, mientras que en otras ocasiones, las fisuras son el producto de lecturas contestatarias que desafían interpretaciones canonizadas de obras que han sido leídas dentro de una tradición políticamente exclusivista y socialmente privilegiada.

Si se toma en cuenta el papel social $y$ reivindicador que la literatura ecuatoriana ha jugado desde el siglo XVIII, y la medida en que ha sido empleada en la construcción conceptual de la nación desde el siglo XIX, se comprenderá la lógica de recurrir a la literatura para examinar el lugar que lo afro ha ocupado en el imaginario nacional. Además, puesto que el propósito mayor de este libro trasciende fronteras raciales y nacionales, los textos analizados son de escritores negros y no-ne- gros, y gran número de las fuentes de consulta viene de todas las latitudes de la diáspora afroamericana. En cierta manera, tanto la selección de materiales como su aplicación constituyen una manifestación clara de la transculturación, de ese constante ir y venir de influencias y coincidencias que rompen esquemas unidimensionales y equivocadamente aislados.

Lo afro y la plurinacionalidad: el caso ecuatoriano visto desde su literatura consiste de siete capítulos. En el primero, se plantea el problema de un racismo sutil que, a pesar de la retórica de un mestizaje nacional, ha mantenido a los negros en los márgenes de la sociedad ecuatoriana. En los capítulos II, III y IV, mediante un análisis de la caracterización del negro en varias obras de escritores no-negros de la Costa ecuatoriana, se examina un reconocimiento paulatino de la centralidad de lo afro en el vivir costeño del Ecuador, un fenómeno que pone en tela de juicio los parámetros tradicionales de una identidad nacional andina. En los tres capítulos restantes, el análisis se dirige a obras escritas por afroecuatorianos quienes siguen luchando por establecer un equilibrio entre su condición doble de ser afro y ecuatoriano en una sociedad que tradicionalmente ha desacreditado todo discurso racial como un atentado contra la supuesta unión nacional. 4

A diferencia de otros investigadores que han resaltado la singularidad y la especificidad de lo afroecuatoriano, estableciéndolo como una categoría legítima de estudio de por sí, vuelvo a señalar que en 
el presente libro he ampliado la discusión para demostrar que lo afroecuatoriano también existe en varios contextos simultáneos. De hecho, por su identificación con la diáspora afroamericana, es transnacional y, por consiguiente, las experiencias de las comunidades negras del país pueden contribuir mucho a una resolución justa del debate sobre la plurinacionalidad ecuatoriana. Al mismo tiempo, la condición diaspórica de lo afro es un recuerdo más de que lo ecuatoriano también rebasa fronteras artificiales y arbitrarias, sean éstas geográficas o mentales. Por lo tanto Lo afro y la plurinacionalidad: el caso ecuatoriano visto desde su literatura es un modesto intento de comprender y de reafirmar la centralidad de todos los grupos y de todos los países en un mundo transcultural al cual le urge terminar con toda una "historia humana de conquista y de destrucción que se han justificado en nombre de mitos de pureza y privilegio" (Ashcroft, et al., 36; traducción mía).

\section{Notas}

1 Es de notar que Ortiz se les había adelantado con varias décadas a aquellos teóricos postcoloniales y postmodernos cuyas ideas acerca de la "hibridez" y el "multiculturalismo" han ejercido gran influencia en círculos académicos de Europa y de Estados Unidos durante los últimos años del siglo XX.

2 Djelal Kadir ha observado que la otredad no es un fenómeno absoluto ni ha de considerarse un fenómeno exótico destinado a ser romantizado o mitologizado. "De hecho, la otredad puede ser lo que más tenemos en común” (4; traducción mía).

3 Aunque Ortiz escribió específicamente sobre el caso cubano, él era consciente de una mayor proyección para su análisis: "El concepto de transculturación es cardinal y elementalmente indispensable para comprender la historia de Cuba y, por análogas razones, la de toda la América en general" (90).

4 Aunque los capítulos I, III, IV y V fueron publicados anteriormente en varias revistas anotadas en la bibliografía de este libro, he incorporado numerosos cambios en los textos para actualizarlos y para mantener un desarrollo coherente de ideas críticas a través de todo el libro. 


\section{Capitulo I \\ La literatura afroecuatoriana en el contexto nacional: ¿Ilusión o realidad?}

\section{Acotaciones preliminares}

La relación estrecha entre el texto literario y su contexto sociohistórico, entre la escritura y su recepción, viene a ser el punto de partida de mis reflexiones acerca de lo afro, la plurinacionalidad y la literatura ecuatoriana. Wolfgang Iser ha observado que "cualesquiera que sean los juicios críticos transmitidos, la obra reflejará también varias actitudes y normas del público y, por consiguiente, se podrá decir que la literatura funciona como un espejo del código cultural que condiciona dichos juicios críticos" (28; traducción mía). Con este primer capítulo, pondré de relieve la medida en que la literatura afroecuatoriana apunta a valores sociales que han encerrado al negro, y todo lo que se sabe de él, en un espacio ambiguo y contradictorio. En efecto, el tema de lo afroecuatoriano resulta ser una especie de Caja de Pandora, una caja que, al abrirse, echa al aire otros temas que, en su conjunto, forman el mosaico de la nación ecuatoriana, una nación múltiple y diversa que sigue buscándose dentro y fuera de su literatura.

Puesto que la creación y la recepción de la literatura afroecuatoriana son inseparables, mis inquisiciones se mueven contínuamente hacia una sociedad que también es una creación en ciernes que busca a sus propios lectores. De modo que se encontrarán a continuación muchas de las inquietudes que analizaré a lo largo de este libro, inquietudes fundamentales para una aprehensión cabal de lo afroecuatoriano en el escenario plurinacional.

A primera vista, parece que debe haber suficientes razones históricas para afirmar que el negro ocupa un lugar de cierto prestigio social en el contexto nacional del Ecuador. A diferencia del negro de otros países latinoamericanos que comenzó su historia en el Nuevo Mundo como esclavo y que luego se convirtió en cimarrón, el ecuatoriano invirtió el proceso de la esclavitud tradicional debido a un naufragio fortuito en 1553, año en que los primeros negros que llegaron al Ecuador lograron escaparse de los negreros y establecerse en una zona que más tarde se conocería como la provincia de Esmeraldas. ${ }^{1}$ Estos orígenes de rebeldía y libertad prepararon el terreno para que, a través de los siglos, se desarrollara en el Ecuador una concentración numerosa de negros 
capaces de construir y de fomentar una identidad cultural afroecuatoriana. De hecho, parte de esta conciencia se ha enriquecido con el orgullo de haber dado a la patria a figuras tan ilustres como Carlos Concha, defensor acérrimo del alfarismo/liberalismo de comienzos del siglo XX, y Adalberto Ortiz, Nelson Estupiñán Bass y Antonio Preciado, escritores célebres de la literatura nacional de este mismo siglo $\mathrm{XX}$. En cuanto a estos últimos tres, se ha afirmado que "a diferencia de la situación de escritores negros en Uruguay y Perú, estos afroecuatorianos han sido incorporados en la tradición literaria nacional; sus obras han sido reseñadas y se están publicando en casas editoriales bien establecidas" (Lewis, Afro-Hispanic Poetry 19401980..., 83; traducción mía). De hecho, en 1993, Estupiñán Bass recibió el Premio Eugenio Espejo de Literatura, el máximo galardón nacional en lo que respecta a la cultura en general.

Además de esta aceptación por la crítica literaria nacional, algunos han visto en la creación afroecuatoriana una proyección mayor que la de los intereses particulares del negro. Por eso es que al referirse a Adalberto Ortiz y su novela Juyungo (1943), se ha puntualizado que ésta es

una novela clásica porque resalta la universalidad de la experiencia de los negro$s$-el racismo en Ecuador es poco diferente al de cualquier otro lugar. Además, Ortiz utiliza la experiencia de los negros para lograr lo que parece ser una propuesta mayor, a saber, la de demostrar que "el drama del negro ecuatoriano es el mis- mo que el drama del indio y del cholo, es decir, es el de cualquier persona explotada, sea la que fuera su raza o nacionalidad...." (Jackson, Black Writers ..., 122; traducción mía)

Tal vez esa amplitud de propósitos y de conciencia social se comprenderá mejor al recordar que la presencia del negro en el Ecuador no ha de limitarse a un solo espacio geográfico llamado Esmeraldas. De hecho, ya en 1937, el cuentista costeño, José de la Cuadra, había señalado la importancia histórico-cultural del negro en la formación del montuvio ecuatoriano, describiéndolo como "la resultante de la fusión del indio con el negro y en la que el correr de los siglos ha depositado gotas de sangre blanca, y es fruto, además, de la herencia dejada por las antiguas importaciones africanas de los terratenientes esclavistas" (8). De modo que, si se toma en cuenta el sector esmeraldeño con el del montuvio, la Costa ecuatoriana se perfila de una manera muy especial, haciendo necesario cuestionar ciertos conceptos tradicionales sobre las llamadas "esencias" del Ecuador.

Pese a ese trasfondo sociohistórico y socioliterario aparentemente lleno de posibilidades para que la cultura afroecuatoriana floreciera, la supuesta aceptación del negro ecuatoriano como componente integral del contexto nacional ha sido más bien un "simulacro." En lo que respecta a los afroecuatorianos, el clivaje que existe entre lo que algunos dicen (no hay racismo, por ejemplo) y lo que se vive (la marginalidad) es demasiado patente para seguir aferrándose a un concepto utópico de 
mestizaje que, en muchos casos, ha constituido un proceso de blanqueamiento o de linchamiento étnico ("ethnic lynching"). Es así que en un estudio intitulado, "Teoría del simulacro," Fernando Tinajero ha constatado (aunque sin haberse referido concretamente al afroecuatoriano) que existe en el Ecuador un vacío entre las explicaciones oficiales de la cultura nacional y las verdaderas condiciones que marcan esta(s) cultura(s) nacional(es). Según él ha planteado:

El valor de la Palabra no está dado por la mayor o menor proximidad a las teorías fundamentales sobre la realidad, sino por su grado de coherencia con ella. Esa coherencia otorga a la Palabra su valor primordial, que es la autenticidad, aunque por sí misma no garantiza la Verdad. La Verdad, para decirlo simplemente, no sólo es Palabra auténtica, sino también Acto consecuente. La palabra para ser propiamente Palabra, no sólo es Verbo, sino también Acción. (en Sánchez Parga, Tinajero, Araujo, et al., Signos de futuro: La cultura ecuatoriana en los 80,51)

Y, a continuación, Tinajero concluye: "Donde no hay coherencia no hay autenticidad, pero puede haber apariencia de verdad. Donde no hay coherencia reinan las palabras y los gestos, esforzándose por sustituir a las Palabras y los Actos. El dominio de las palabras y los gestos es el Simulacro" (51). En efecto, y en la medida en que un mestizaje imperfecto e incompleto ha sido manipulado como un mito nacional de una sociedad sin racismo, todo intento de contextualizar la literatura afroecuatoriana como una expresión cultural acerca del lugar que el negro ha ocupado en la historia nacional tiene que tomar en cuenta el predominio de un discurso oficial cuyas palabras, con demasiada frecuencia, han tenido mucho más que ver con las apariencias que con las "Verdades."

No se debe olvidar que el crítico, Richard Jackson, ya ha destacado la ambivalencia inherente a un deseado mestizaje que para los escritores afrolatinoamericanos ha constituido un

proceso de fusión cultural y étnica que ha disminuido su número. Ellos creen, sin embargo, que pese a obstáculos racistas, el ambiente creado por el proceso permite un desarrollo de una negritud como una justificación de lo negro, pero dentro del contexto de la composición mezclada de las naciones latinoamericanas. (The Black Image... 92; traducción mía)

Es precisamente este ideal de fusión que Ortiz, Estupiñán Bass y Preciado han utilizado al definir sus respectivos proyectos literarios. Por su parte, Ortiz ha constatado:

La negritud para los americanos no puede ser un "retorno a Africa," o una defensa exagerada de la cultura africana, sino, más bien, un proceso de mestizaje étnico y cultural en este continente que se puede comprender cabalmente en estos tiempos no sólo en sus manifestaciones físicas de matrimonios mixtos, sino también en las ramificaciones estéticas de un movimiento literario particular, como también en la música folklórica, creencias y supersticio- 
nes. ("Negritude in Latin American Culture" 76; traducción mía) $)^{2}$

Desgraciadamente, entre una primera etapa en la que cada uno de estos tres escritores afroecuatorianos ha incursionado hondamente en sus raíces africanas, y otra etapa posterior en la que los tres han tratado de trascender el rescate de los orígenes (i.e., la identidad racial como un sine qua non), algo se ha perdido. Mientras que Ortiz, Estupiñán Bass y Preciado han seguido desarrollando y ampliando su aprehensión del negro ecuatoriano, pocos ecuatorianos los han acompañado $y$, por consiguiente, en la actualidad "el negro esmeraldeño continúa explotado y marginado-además folklorizado-en este mundo en el que imperan el racismo y la segregación, simples esquemas que disfrazan la injusticia y la opresión social..." (Hidalgo 39). Y, más allá de la provincia de Esmeraldas, en Guayaquil, concretamente, se ha observado que "el negro ha sido uno de los grupos importantes del mestizaje del cual somos producto..." (Garay, "La élite económica de los negros en Guayaquil de 1742 a 1765," 120). Sin embargo, "En nuestra ciudad ser negro es un tema conflictivo al máximo, para las familias sean éstas de la clase social que fueren, alta, media o popular. A ninguna les interesa y peor aún aceptan [sic] el tener sangre africana en sus venas" (Garay, "Los negros en Guayaquil en 1850,” 123).

La paradoja está clara. Se descubre, por un lado, que la historia del negro en el Ecuador se ha caracterizado por un espíri- tu de rebeldía, de resistencia y de creatividad. Todo eso se vislumbra, primero, a partir de sus orígenes de cimarrón cuando llegó al país en el siglo XVI; después, mediante su defensa de los ideales liberales de Eloy Alfaro a comienzos del siglo XX; y luego, por la vitalidad constante de su aporte sociocultural, cuyas múltiples manifestaciones se patentizan de una manera muy especial en las letras nacionales, y que ha dado al país una distinción a nivel continental. Por otro lado, sin embargo, surge la triste verdad de que en vez de constituir realmente una fuente de orgullo nacional, la cultura afroecuatoriana, más bien, continúa considerándose una aberración folklorizada. Es así que se ha observado: "En la población negra de la provincia de Esmeraldas existe una importante expresión cultural en música, danza y poesía, lamentablemente poco conocida y estudiada hasta hoy" (Hidalgo 11). De una manera más concreta que pone de relieve el estado ilusorio de la supuesta aceptación de escritores como Ortiz, Estupiñán Bass y Preciado, el crítico, Henry Richards, ha comentado en su estudio intitulado, La jornada novelística de Nelson Estupiñán Bass. "Después de registrar fuentes bibliográficas ecuatorianas en busca de valoraciones críticas de la narrativa de Nelson Estupiñán Bass, concluí que este distinguido escritor esmeraldeño no es profeta en su tierra, ya que su obra no ha recibido en el Ecuador la atención que merece" (xi).

Los silencios de las diferentes historias oficiales (y de la crítica literaria, también) que han mantenido al negro en una 
periferia nacional durante los últimos cinco siglos en el Ecuador han sido el resultado, en parte, de una confusión de lo que es raza y etnicidad en el país. Ya se ha advertido:

Uno de los problemas más complejos que se ha encontrado al analizar la población ecuatoriana es el de definir raza y etnicidad. Por la ausencia de definiciones aceptadas sobre raza y etnicidad, los cálculos sobre el tamaño de varios grupos tienden a revelar más sobre los prejuicios de la gente que hace los cálculos que una realidad objetiva, propiamente. (Alexander 24; traducción mía)

Por consiguiente, las estimaciones demográficas más actualizadas sobre la población ecuatoriana todavía se destacan por su imprecisión en lo que respecta al negro. Entre los diez millones y medio de ecuatorianos oficialmente reconocidos en 1990 en diferentes censos, por ejemplo, el porcentaje de negros variaba desde un 3\% hasta un $10 \%$ de la población general. Y aunque parece haber un acuerdo sobre la población negra de Esmeraldas (i.e., 300.000 habitantes), es muy raro que se matice la composición del mestizaje nacional en otros términos que no sean los de la mezcla de indios y blancos ("Mixed Indian and Spanish") (Atlas histórico-geográfico del Ecuador). En efecto, la relación entre raza y color de piel constituye una cuestión harto difícil de precisar en el Ecuador. Norman Whitten, Jr. la trató lúcidamente en su Black Frontiersmen: A South American Case.
[...] pese a los diversos cálculos e índices sobre lo racial en el litoral y en otros lugares, un hecho está clarísimo. Lo negro es lo opuesto a lo blanco, y conceptos nacionales del mestizaje en Colombia y Ecuador son lo opuesto a lo negro precisamente de la misma manera que lo blanco se contrasta con lo negro. (199; traducción mía)

Ya mencioné a José de la Cuadra, quien había definido al montuvio ecuatoriano como una mezcla compleja que sí se ha nutrido de lo negro. De hecho, gran parte de la Costa ecuatoriana al sur de Esmeraldas (especialmente, las provincias del Guayas y Los Ríos) se distingue por esta complejidad racial y cultural que rompe cualquier esquema que pretenda borrar la presencia negra del llamado mestizaje, por un lado, y que pase por alto los vínculos socioculturales caribeños omnipresentes en este país andino, por otro lado. ${ }^{3}$ Sin duda alguna, el fuerte regionalismo entre la Costa y la Sierra que ha marcado profundamente la historia nacional-junto con el peso de ciertos conceptos exclusivistas de "lo andino"- ha impedido una apreciación cabal de lo negro como componente cultural vital y medular del país. Además, el centralismo burocrático y sociocultural anclado en la Sierra que sigue siendo una parte constitutiva del mentado regionalismo, también ha contribuido a opacar la verdadera amplitud de la cuestión raza/etnicidad en el Ecuador. ${ }^{4}$ No es una mera casualidad que el punto de arranque de lo mucho que se ha dicho en la última década del siglo XX acerca del 
Ecuador y de su composición multiétnica y plurinacional se haya fundamentado primordialmente en los sectores indígenas. Es decir, una supuesta apertura en la concepción de lo nacional sigue definiéndose a partir de parámetros centralistas que, si bien ha iniciado una importantísima revaloración de los diversos sectores indígenas, también ha alejado del debate gran parte de lo "no andino" de este país "andino." 5

Sería un grave error considerar esta miopía como algo aislado o como una mera señal de un supuesto resentimiento de los costeños. Libro tras libro publicado en el país por las principales editoriales en los años 80 sobre cuestiones como la identidad nacional, la relación entre nación y estado o la naturaleza pluralista del Ecuador, se ha caracterizado por su silencio sobre lo afroecuatoriano y, por ende, por lo costeño. En un estudio que ejemplifica el fenómeno anotado, se lee:

El proceso de democratización iniciado a fines de los 70 y principios de los 80 , entre otros efectos socioculturales... ha creado las condiciones no sólo para que el discurso sobre la cultura e identidad nacionales se fragmentara, sino también para que las culturas regionales (cruzadas por reivindicaciones históricas y actuales demandas al nuevo Estado) reclamaran el estatuto y ejercicio de su diversidad. No resulta por ello extraño que el tema discursivo que ha predominado con más amplias e intensas interpelaciones haya sido el de las "diversidades culturales" [...]. (Sánchez Parga, Signos de futuro, 27)
Pero, al mismo tiempo, y a pesar de una aparente sensibilidad por la naturaleza diversa del país, el citado texto se refiere a "la sociedad ecuatoriana de 1980" como "una simbiosis de tradición y modernidad, que en no pocos de sus rasgos, participa tanto de la 'cultura burguesa' como de la 'cultura indígena' del país" (19). Y mientras se pone de relieve el hecho de que "la década de los 80 ha escenificado una nueva presencia de los indígenas [...]" (18), uno ha de sentirse un poco perplejo ante la ausencia de lo afroecuatoriano.

En los pocos estudios dedicados a diversos aspectos de lo negro en el Ecuador, una constante que sale a la luz tiene que ver con la necesidad de contrarrestar los silencios oficiales. De ahí la advertencia de que quienes tradicionalmente "forman parte de la población afro-esmeraldeña, no han encontrado mención alguna de sus antepasados ni de sus ricas manifestaciones culturales, en donde reconocer sus raíces y reforzar su identidad" (García, Cuentos y décimas afro-esmeraldeñas, 5). Entre las tentativas de rescate cultural que más han aportado a la justa ubicación del negro dentro del contexto ecuatoriano, se encuentran aquellas en las que se ha destacado, sobre todo, la vitalidad de las tradiciones orales cuya supervivencia se debe a gente de gran creatividad y talento. ${ }^{6}$ Es instructivo recordar que "los procesos de cultura son procesos sociales, y que sólo los diferentes actores de la sociedad son sujetos de procesos culturales" (Sánchez Parga, "Cultura, sociedad y estado," 21). 
De una forma u otra, toda noción sobre esta condición de "sujeto" del negro ecuatoriano-es decir, de su capacidad de creación y de resistencia - se ha perdido fuera de las comunidades negras del país justamente cuando los grupos indígenas, también tradicionalmente oprimidos y silenciados, parecen estar apropiándose de su auténtico espacio dentro de la nación ecuatoriana.

No quisiera insinuar que los indígenas estén cerca de un triunfo definitivo, ni que hayan superado cinco siglos de opresión. Pese a la receptividad y solidaridad que diversos grupos progresistas han expresado a favor de las causas de reivindicación indígena, los principales sectores blanco-mestizos dominantes de la sociedad nacional siguen sujetando las riendas del poder. Lo que interesa, sin embargo, es cómo en la actual coyuntura histórica, que aparentemente se presta a todo esfuerzo por democratizar al país, el negro ecuatoriano, con todos sus matices de raza y cultura, continúa siendo un elemento ausente $\mathrm{o}$, cuando mucho, marginado en lo que respecta a la percepción pública del escenario nacional. ${ }^{7}$

Vuelvo a resaltar lo paradójico de esta ausencia en un país donde tres escritores se han establecido como fuerzas mayores dentro de la literatura afrolatinoamericana y, más aún, como representantes plenamente integrados a los cenáculos literarios de más prestigio nacional. A diferencia de Huasipungo, Los Sangurimas o Don Goyo, novelas rectoras en las que el público lector pudo descubrir las trage- dias vivas del indio, del montuvio o del cholo, las obras de Ortiz, Estupiñán Bass y de Preciado no constituyen solamente un acercamiento interpretativo hacia un grupo marginado del país, sino que son el producto mismo del afroecuatoriano. Es decir, el negro ecuatoriano no ha tenido que esperar que otros lo defendieran, que lo estudiaran o que lo interpretaran. El negro, en fin, ha creado su propia voz dentro de la literatura escrita que, curiosamente, no ha sido asimilada o retomada mayormente por otros sectores del país. En vez de una integración, se ha producido el aislamiento del afroecuatoriano, encerrándolo en un espacio geocultural todavía distante de un centro nacional considerado andino y/o blanco-mestizo.

Los estudios y textos que han tratado al negro en el Ecuador, y que podrían dar la impresión de que mis observaciones pecan de ser forzadas y hasta exageradas, han sido, hasta la fecha, esporádicos y poco difundidos. De hecho, esta falta de continuidad y de constancia ha impedido que lo afroecuatoriano, con todos sus matices, deje de ser algo más que una mera curiosidad. Esta afirmación parece comprobarse al leer el prospecto de la Historia de las literaturas del Ecuador, un proyecto de historiografía literaria ambicioso que la Corporación Editora Nacional del Ecuador había decidido auspiciar. ${ }^{8}$ Entre los objetivos principales anunciados en el dicho prospecto estaba el de contrarrestar la "visión etnocéntrica que hasta hoy ha prevalecido en los estudios de nuestra literatura [y que] ha privilegiado en forma exclusiva 
a las manifestaciones literarias en lengua castellana y originarias del sector blancomestizo de la sociedad..." (3). Desgraciadamente, de las dos mil páginas proyectadas, sólo veinte habían sido designadas para un ensayo general intitulado, "Literatura afroecuatoriana."

Este tipo de omisión de una historia que pretende reivindicar y difundir las diversas literaturas nacionales parece sintomático de la situación general que sigue viviendo el negro ecuatoriano en el contexto nacional. Además, constituye una especie de llamada general para reflexionar abiertamente sobre el papel que ha jugado $y$, que ha de jugar, el escritor afroecuatoriano en todo el proceso de búsqueda de identidad nacional. Lógicamente, hay que reconocer la necesidad y lo acertado del interés de cualquier escritor de trascender su mundo inmediato y particular. Antonio Preciado, por ejemplo, reflejó este deseo de lo universal al comentar que "mi poesía en su totalidad, aunque toque los temas negros como afirmación de mi identidad cultural, de la que me enorgullezco, voy al abrazo del hombre en general. [...] Yo voy al abrazo de todos los seres humanos porque la humanidad es de todos los seres humanos" " Entrevista con Antonio Preciado" 26). Ante este mensaje, sin embargo, está la observación del crítico, Richard Jackson:

Por toda América Latina, la negligencia benigna y el mestizaje han creado un sentido falso de seguridad y una conciencia falsa en América Latina que, como St. Clair Drake ha señalado, "impide una lu- cha efectiva." Esta ausencia de lucha por su parte minimiza el surgimiento de una Estética Negra, por lo menos en el sentido del Nacionalismo Negro. (Black Writers in Latin America 102; traducción mía)

Aunque no es mi intención insinuar aquí que el nacionalismo afroamericano de Estados Unidos constituya para el intelectual afroecuatoriano una alternativa apropiada o deseable, sí quisiera resaltar el peligro inherente a un discurso que, mientras aspira a lo nacional/universal, termina siendo refuncionalizado por una sociedad que, consciente o inconscientemente, se niega a reconocerlo como un elemento integral de lo ecuatoriano. Es decir, si Juyungo y Cuando los guayacanes florecían, por ejemplo, se leen como novelas de denuncia social principalmente desde una perspectiva supuestamente nacional/universal, no es de extrañar que se pierda de vista la especificidad de la resistencia emprendida contra la opresión sufrida por los negros ecuatorianos como miembros de una raza particular. Entre las posibles consecuencias literarias y extraliterarias que pueden surgir de tal lectura está la ya mentada miopía blanco-mestiza.

Por lo tanto el proyecto literario mediante el cual Ortiz, Estupiñán Bass y Preciado han procurado superar esquemas localistas parece haber dado lugar a una especie de lectura de apropiación cultural que, en no poca medida, ha desarmado doblemente dicho proyecto. Por un lado, y en nombre de una deseada nacionalidad/universalidad, el mundo del ne- 
gro ha sido absorbido de tal forma que, en efecto, se ha eliminado la necesidad de tratar frontalmente la situación concreta y complejísima del afroecuatoriano en el contexto nacional. Por otro lado, y por haberse dejado sumergir dentro de un crisol utópico de mestizaje, la cultura negra todavía no figura de un modo patente en ninguna concepción oficial de la nacionalidad. En efecto, la situación afroecuatoriana no parece estar muy lejos de la que comentó Aimé Cesaire: "Il y a deux manières de se perdre: par ségrégation murée dans le particulier ou par dilution dans l'universel'" (en Miller, 139).

Preciado ha afirmado, y con toda razón, que el "reconocimiento ancestral en nosotros es una necesidad, es bueno saberlo- ¡cómo no!-pero no como para quedarse anclado en ese reconocimiento" ("Entrevista con Antonio Preciado" 26). Sin embargo, el desfase que existe entre un proyecto literario de superación multifacética y un medio social, cuyas necesidades y cultura todavía se encuentran hundidas en el olvido y la indiferencia, hace imprescindible una reevaluación de propósitos y de estrategias. No cabe duda de que el éxito de las obras de Ortiz, Estupiñán Bass y Preciado ha sido relativo y parcial. Ha habido un cortocircuito; y, por lo tanto, todavía se mantiene vigente lo sustancioso del lamento de aquellos tres conciertos de Cuando los guayacanes florecían que "Querían expresar sus dudas, explicar su triste condición de esclavos y pedir una aclaración. El capitán decía que había que defender la libertad. Pero, ¿qué libertad habían tenido ellos?" (82).

Para concluir, no se puede responsabilizar a Ortiz, a Estupiñán Bass o a Preciado por las lecturas de una apropiación cultural ya comentada, ni tampoco se ha de esperar que la literatura como tal realice grandes transformaciones sociales de por sí. No obstante, creo que si los intelectuales afroecuatorianos no toman la iniciativa de contrarrestar dicha apropiación llevada a cabo por los sectores blancomestizos, pese a los múltiples obstáculos que hubiera, todo el proceso de búsqueda de identidad nacional seguirá estancándose en un desconocimiento propio de una visión parcial y parcializada - producto de un mestizaje homogeneizador-que, en el fondo, sirve de pantalla de humo destinado a detener una verdadera democratización nacional. En fin, sin un proyecto abiertamente afrocéntrico que acompañe otros proyectos multiétnicos en el país, se corre el peligro de perder de vista lo que Ortiz había señalado acerca del Ecuador hace ya medio siglo en Juyungo: "El que no tiene de inga, tiene de mandinga" (277).

\section{Notas}

1 Aunque hay alguna discusión acerca de la fecha exacta de la llegada al Ecuador de estos primeros negros y de las condiciones en que aparecieron, los investigadores que mejor conocen este aspecto de la historia ecuatoriana no cuestionan en absoluto el espíritu rebelde y libertario de los orígenes afroecuatorianos. Para más información sobre estos orígenes, véase el capítulo III en el cual me refiero a los comentarios de Juan García Salazar y Leslie Rout, Jr. 
2 Para un análisis detallado de Ortiz y lo problemático de su concepto de la negritud y el mestizaje, véase el capítulo V donde estudio Juyungo en el contexto del realismo social.

3 Un interesante paralelo que ayuda a relacionar lo caribeño con la costa andina, especialmente en lo que respecta a Colombia y Ecuador, se vislumbra en un estudio sobre la cultura pluralista del Caribe realizado por Antonio BenítezRojo. Al referirse a una escena común de un mercado público, él señala que "es un encuentro de ritmos en que hay mucho de lo africano, pero también de lo europeo; no es una mezcla 'mulata', si ese término pretende destacar una especie de 'unidad'; es un espacio polirrítmico que es simultáneamente cubano, caribeño, africano y europeo" (81; traducción mía).

4 John Leddy Phelan ha analizado la influencia de la historia de Esmeraldas en esta escisión nacional de Costa/Sierra. Según él comenta, el no haber establecido hace tiempo un puerto dinámico en Esmeraldas, "La Sierra quedó virtualmente aislada del resto del mundo por trescientos años. [...] No fue hasta el siglo XX cuando los patrones tradicionales de vida de la Sierra fueron desafiados por los nuevos aires de la modernidad que llegaban desde la metrópoli de la Costa, Guayaquil. Si Esmeraldas hubiera sido colonizada en el siglo XVII, el carácter subsecuente de la sociedad en la Sierra podría haber sido menos tradicional y, por lo tanto, más receptivo a lo nuevo. De ahí que un equilibrio más dinámico entre la Sierra y la Costa podría haber emergido mucho antes que en el presente siglo" (21; traducción mía).

5 No se debe olvidar que el Ecuador es, también, un país amazónico.

6 Un trabajo ejemplar de consulta acerca de las tradiciones orales es Décimas esmeraldeñas (1982) de Laura Hidalgo.

7 Me refiero aquí a "la percepción" de las mayorías del país. Para un análisis de las comunidades negras como una fuerza democratizante y pujante, véase el último capítulo sobre el "Proceso de las Comunidades Negras."

8 Lamentablemente, parece que el proyecto quedó estancado y, hasta la fecha, no ha sido publicado. 


\section{Capítulo II \\ Personajes negros y realismo social. El caso del Grupo de Guayaquil}

\begin{abstract}
"Magia negra, mentalidad primitiva, animismo, erotismo animal, todo esto refluye hacia mí. Todo esto es lo que caracteriza a los pueblos que no han seguido la evolución de la humanidad." (Frantz Fanon, Piel negra, máscaras blancas)
\end{abstract}

El concepto tradicional de una nación mestiza llamada Ecuador ha ofuscado con frecuencia las diferencias de perspectiva que marcan las relaciones socioculturales que existen entre múltiples grupos del país y, en particular, entre los negros y demás ecuatorianos. Esta división sale a flor de piel al yuxtaponer dos afirmaciones acerca del tema racial en el Ecuador. Por una parte, se destaca un comentario del escritor mestizo, Demetrio Aguilera Malta, quien ha negado la existencia de un "problema racial" en el país (aunque sí reconocía, curiosamente, que había discriminación racial), mientras que Juan García Salazar, dirigente negro de Esmeraldas, ha denunciado como problema de fondo el racismo preponderante en el Ecuador. ${ }^{1}$

Aunque en primera instancia se podría desprender de lo anterior una polarización endurecida de conceptos y actitudes, sería más fructífero rescatar el potencial dialogal de estos dos puntos de vista para, así, aprehender cabalmente la complejidad característica de las relaciones interraciales en el Ecuador. En cierta medida, la cuestión racial planteada aquí se remite a una plurinacionalidad de la cual se está discutiendo si sus diversos discursos han de ser complementarios o adversarios. Es en este contexto que pienso analizar la representación de algunos personajes y temas negros que aparecen en importantes obras del Grupo de Guayaquil. Con el trasfondo de las tensiones y contradicciones inherentes al debate en torno a la literatura escrita sobre los negros versus la literatura escrita por los negros, pretendo poner de relieve las posibilidades interpretativas y enriquecedoras propias de una lectura afrocéntrica de varias obras representativas de aquellos escritores ya clásicos de la literatura ecuatoriana, a saber: Demetrio Aguilera Malta (1909-1981), José de la Cuadra (1903-1941), Joaquín Gallegos Lara (1911-1947), Enrique Gil Gilbert (1912-1973) y Alfredo Pareja Diezcanseco (1908-1993). ${ }^{2}$

A estas alturas, no hace falta entrar en detalles al reconocer la importancia que el Grupo de Guayaquil ejerció en el desarrollo de la literatura del Ecuador y de América Latina en general. ${ }^{3}$ Lo que intere- 
sa aquí es señalar el compromiso social que marcó la obra que los cinco gestaron, especialmente en lo que se refería a los marginados de la Costa ecuatoriana. Dentro de su preocupación por la liberación y la justicia, era natural que ellos incorporaran al personaje negro a sus textos literarios ya que los negros, junto a los montuvios y los cholos, constituían una parte extensa del pueblo costeño al cual el Grupo de Guayaquil pretendía reivindicar.

A pesar de sus buenas intenciones, sin embargo, su caracterización del negro pecaba a menudo de ser estereotípica y, lamentablemente, la complejidad del drama vivido por los negros ecuatorianos corría el riesgo de perderse en una denuncia social que no contemplaba la raza más allá de su dimensión fenotípica. La opinión de Aguilera Malta ya citada viene al caso puesto que el realismo social que se practicaba en los años 30 en el Ecuador estaba anclado en la lucha de clases, el sine qua non del pensamiento de la mayoría de los intelectuales más progresistas y de más influencia de la época. ${ }^{4}$ En efecto, éstos asumían que no tenía sentido hablar en términos raciales en países como el Ecuador donde prevalecía el mestizaje como mito nacional.

Las limitaciones del mestizaje continúan afectando las condiciones generales en que se encuentran los afroecuatorianos, por un lado, y las percepciones que la sociedad dominante tiene al respecto, por otro. Conviene traer a colación aquí la conclusión de otro investigador:
“[...] el Estado utiliza la noción del mestizaje como argumento para eliminar la posibilidad de permanencia de las identidades indias diferenciadas. La ideología del mestizaje se reactiva bajo este propósito, por lo que en este momento y en estas circunstancias el concepto de mestizo se vacía de todo contenido y se convierte en negación de cualquier especificidad sociocultural" (Espinosa Apolo 219). Aunque lo citado trata de la situación concreta de los indígenas, su aplicación a la de los negros del país me parece pertinente y profundamente instructiva.

Para evitar excesivas generalizaciones, hay que reconocer que el Grupo de Guayaquil y su producción literaria, especialmente en lo que tocaba a los personajes negros, no arrancaron de un proyecto de oclusión o de negación de las diferencias sociales. Es archiconocido que estos escritores vieron en el mestizaje un vehículo de democratización y, en este sentido, su labor de creación sigue representando un gran avance en el desarrollo paulatino de una conciencia viva de lo multicultural y lo plurinacional del Ecuador. En efecto, la solidaridad que ellos habían expresado en sus obras para con los sectores oprimidos del país (y de la Costa, sobre todo) amplió las posibilidades de incorporar a los negros ecuatorianos (i.e., hacerlos más visibles) en el imaginario nacional, por lo menos en lo que respectaba al pueblo. No me parece una exageración sugerir que Baldomera, aquella mulata prepotente de la novela homónima de Pareja Diezcanse- 
co que se publicó en 1938 y, que comentaré más adelante, simboliza un esfuerzo (aunque truncado) por captar a través de la literatura la presencia vital y hasta medular del negro en la Costa ecuatoriana.

De modo que el proyecto reivindicativo del Grupo de Guayaquil ha tenido importantes implicaciones para el pueblo negro del Ecuador. Sin embargo, puesto que era la presencia social más que la racial la que les había preocupado a los integrantes del Grupo de Guayaquil, muchos de sus personajes negros carecían de la plenitud creativa tan evidente en obras escritas por los negros mismos del país. Esta observación no ha de leerse como una negación de méritos, ni literarios ni sociales, sino como una advertencia de la problemática del tema negro en el país, tanto dentro como fuera de la literatura.

Hay que recordar que la producción literaria del Grupo de Guayaquil no ha sido monolítica y, por consiguiente, la caracterización del negro revela una gran variedad de matices e interpretaciones, no sólo de un escritor a otro, sino entre las mismas obras de un solo autor. Es decir, aunque el material por analizarse tiene como una constante la del negro como símbolo de la explotación y la exclusión, su condición del "otro" muchas veces se ha quedado estancada en lo caricaturesco y, por lo tanto, la denuncia supuestamente democratizante terminaba arraigando aun más en los lectores ciertas actitudes racistas. Las consecuencias de esta contradicción entre propósitos y efectos se hacen patentes al leer el epígrafe de este capítulo. Con ironía, Fanon ha recordado la medi- da en que la "otredad" puede reproducir la falsa y opresiva dicotomía de "civilización y barbarie" que tanto daño ha hecho "a los pueblos que no han seguido la evolución de la humanidad."

Literatura escrita sobre negros versus literatura escrita por negros: un contexto teórico para examinar algunas obras del Grupo de Guayaquil

Aunque parezca una perogrullada, la experiencia de ser negro es imprescindible si se espera captarla cabalmente. Entiendo lo de "ser negro" en un sentido cultural que trasciende nociones biologistas y que implica una conciencia de toda una trayectoria histórica. Estas premisas no son una negación de la capacidad de los no-negros de solidarizarse con la gente negra ni de la posibilidad de escribir lúcidamente sobre temas propios de los negros. ${ }^{5}$ Más bien, insisto en el diálogo que privilegia la voz del negro al mismo tiempo que valora la co-participación de los demás. Mientras más oportunidades tengan los negros de hacerse escuchar como autoridades de sus propias experiencias, más completo será el diálogo que, tradicionalmente, se ha caracterizado por una dislocación de dichas voces. Es decir (siguiendo modelos ámpliamente conocidos de la crítica contra el colonialismo), los no-negros se apropiaron de la palabra para imponer su interpretación más imaginada que vivida del mundo de los negros.

Vale recordar aquí a Richard L. Jackson, crítico de la literatura afrolatinoamericana, quien ha enseñado (como Mariátegui lo había hecho al analizar el 
indigenismo) que "el Negrismo poético era mayormente un movimiento de intelectuales blancos." Y, más concretamente,

el Negrismo poético del Caribe [...] era [...] primordialmente una explotación de la cultura negra por escritores blancos. [...] Tales poetas no-negros como Alejo Carpentier, Ramón Guirao, Emilio Ballagas y Luis Palés Matos llegaron a ser maestros del sonido verbal y el juego de palabras con o sin sentido. Ellos, como los intelectuales africanistas anteriores, se hicieron expertos en el folklore y en los ritos negros que repitieron estéticamente en su poesía. (The Black Image in Latin American Literature 41; traducción mía)

Según Jackson, los orígenes blancos de este Negrismo poético terminaron produciendo un juego artificial basado en lo pintoresco más que en lo verdaderamente vivencial de los pueblos negros.

El mismo Jackson ha comentado que a pesar de las buenas intenciones, muchos novelistas del siglo XX han sido demasiado paternalistas y arrogantes en cuanto a la representación de sus personajes negros. "Su fascinación para con los negros [...], se dirige hacia lo supersticioso y lo primitivo, hacia la celebración de lo atávico y lo exótico. [...] En suma, [...] algunos novelistas modernos de América Latina usan, o abusan, la cultura negra como un pretexto para perpetuar imágenes unidimensionalmente racistas de la gente negra, $y$

[...] hay escritores del siglo XX que todavía se subscriben al mito del esclavo negro dócil sin espíritu rebelde" (The
Black Image in Latin American Literature 45-46; traducción mía).

Críticos como Jackson pretenden sacar a la luz una tendencia profundamente arraigada en el arte occidental de mantener al negro en un plano exotista que, si bien satisface un sinnúmero de necesidades psicológicas o emocionales del público no-negro, también niega al negro importantes aspectos propios de la condición del ser humano. De modo que, el negro como símbolo de lo primitivo y exótico ha servido para que el intelectual occidental se escapara de los fracasos de su propia cultura y, en el proceso de la creación artística, se ha identificado al personaje negro más con las fuerzas cósmicas de la naturaleza que con el verdadero mundo en que vivía (Jackson, Black Literature and Humanism..., 23). El resultado de este tipo de caracterización ha sido una superficialidad que a menudo se ha prestado a manipulaciones racistas ya que el negro parecía carecer de "un alma, de profundas emociones, de nobles sentimientos y hasta de dignidad humana" (Wilson, en DeCosta, 92; traducción mía).

Se ha insistido así que en América Latina, por ejemplo, "la literatura sobre los negros que los negros mismos han escrito es claramente distinta de la de los autores no-negros debido a sus temas, enfoques y propósitos" (Jackson, xv; traducción mía). A su vez, Frantz Fanon ha constatado al respecto que "Jean Paul Sartre olvidó que el negro sufre en su cuerpo de manera distinta que el blanco." De hecho, "Si los estudios de Sartre sobre la existen- 
cia del otro son exactos (en la medida, insistimos, en que El ser y la nada describe una conciencia alienada), su aplicación a una conciencia negra es falsa. El blanco no es solamente el Otro, sino el señor, real o imaginario por otra parte" (174).

Al leer que "ni Freud ni Adler, ni siquiera el cósmico Jung pensaron en los negros al realizar sus investigaciones" ( $\mathrm{Fa}$ non 193), se comprende hasta qué punto la negritud constituye un conjunto cultural e histórico de experiencias que ha quedado fuera del alcance de los otros. Pero, la diferencia como una categoría de singularidad cultural, o como una identidad propia, no ha de sugerir necesariamente un separatismo infranqueable. Se entiende que nadie vive en un vacío. Por consiguiente, cuando el crítico Marvin Lewis estudió la poesía negra de América del Sur, él observó:

En cuanto al lenguaje, estilo y técnica, la mayoría de estos poetas siguen la tradición hispánica, empleando décimas, romances, liras, sonetos y otras formas europeas. Sin embargo, la poesía es afro en su concepción de la negritud y en su interpretación de la dimensión negra de la cultura sudamericana. Mientras que la poesía expresa actitudes socialmente críticas y es elegíaca al tratar la destrucción de los negros y sus tradiciones, combina los dolores de la esclavitud y la opresión del prejuicio contemporáneo. Al hacer esto, la poesía demuestra que sí hay una constante que unifica a los escritores de la poesía afrohispánica, es la negritud y sus ramificaciones concomitantes. (Afro-Hispanic Poetry 176; traducción mía)
Esta misma complementaridad de lo afro y lo hispánico caracteriza la situación de los negros del Ecuador, los afroecuatorianos. En efecto, cuando los críticos afrocéntricos ponen de relieve ciertas diferencias que dan forma a una identidad negra, no lo hacen con el afán de renunciar nacionalidades o de negar experiencias compartidas con otros grupos. La crítica afrocéntrica más bien pretende despertar una sensibilidad de tolerancia y de respeto mutuo capaz de ratificar la co-participación de los negros en la evolución y desarrollo de sus respectivas sociedades.

Conciencia de la condición doble, cuando no múltiple, del negro se vislumbra a través de toda la diáspora. ${ }^{6}$ Según comentó Ralph Ellison, novelista de Estados Unidos, "No es el color de la piel que produce a un afroamericano, sino la herencia cultural determinada por la experiencia americana, la situación social y política; la participación en aquella 'concordia de sensibilidades' que el grupo expresó mediante circunstancias históricas y a través de la cual ha llegado a constituir una subdivisión de la cultura americana general" (en Gates, The Signifying Monkey, 121; traducción mía). El mismo concepto de identidad fue expresado por Aimé Césaire:

Yo no reniego de las influencias francesas. Quiéralo o no, yo soy un poeta de expresión francesa, y es evidente que la literatura francesa me ha influido. Pero, hay algo sobre lo que insisto mucho, y es que ha habido, a partir de los elementos que me aportó la literatura francesa, ha habido en mí, al mismo tiempo, un esfuerzo por 
crear una lengua nueva, capaz de expresar la herencia africana. Dicho de otro modo, para mí el francés era un instrumento que yo quería plegar a una expresión nueva. Quería hacer un francés antillano, es decir, un francés $<<$ negro $>>$, que, aún siendo francés, lleva la marca $<<$ negra $>>$. (en Depestre 52-53)

En efecto, el reconocimiento de la convivencia constituye un aspecto medular del pensamiento afro $y$, en no poca medida, éste demuestra hasta qué punto las experiencias de los negros con resolver los conflictos inherentes a una identidad múltiple pueden servir de modelo para el proyecto plurinacional que tanto se discute en el Ecuador.

Lamentablemente, afirmaciones que celebran las diferencias todavía tienden a ser sometidas a cualquier cantidad de escepticismo, sospecha y miedo. Hasta en un país tan heterogéneo como el Ecuador se encuentra a muchos individuos que creen que la etnicidad y la nacionalidad se excluyen mutuamente. Por eso el antropólogo Ronald Stutzman ha señalado que "se considera la etnicidad una contracultura que corresponde a un concepto de la naturaleza, del significado y del propósito de la existencia humana que se opone a las percepciones del estado oficial de esas mismas realidades" (en Whitten, Cultural Transformations and Ethnicity in Modern Ecuador, 46; traducción mía). En otra parte, se ha comentado acerca del caso ecuatoriano:

Para los nacionalistas y desarrollistas del estado nacional [the nation-state], los que son negros e indígenas constituyen un "problema" para la nación, uno que puede resolverse sólo cuando la gente de color y de diversas prácticas y creencias culturales acepten las metas de las élites respecto al mestizaje étnico y racial. Desafortunadamente, este supuesto mestizaje deja a los negros y a los indígenas-quienes juntos constituyen más del 30 por ciento de la república-en los antípodas del espectro étnico [...]. (Whitten y Quiroga, "Ecuador," 310; traducción mía)

La negación de las diferencias en nombre de una deseada unión nacional no es solamente contra natura, sino que ha producido un espejismo desde el cual la identidad nacional se ha proyectado borrosamente, dejando la impresión de que pertenecía a todos los ecuatorianos. Ya se sabe que a través de la historia, esta falta de claridad-a veces el resultado de la manipulación, a veces de una ignorancia ingenua-ha permitido innumerables injusticias. Stutzman ha advertido, al respecto, que "el cambio de la etnicidad por la nacionalidad $y$, vice versa, es común, no sólo en el Ecuador sino en la experiencia humana en general. Sin embargo, el significado cultural de dicho cambio todavía no se entiende bien" (en Whitten, Cultural Transformations..., 46; traducción mía).

Yo agregaría a esta última observación de Stutzman que los grupos más directamente afectados por la negación comentada arriba entienden perfectamente las consecuencias culturales del sacrificio de la identidad propia. Por eso es tan necesario el diálogo que, en gran parte, se ha de realizar mediante la lectura y el estudio 
de los textos escritos por ellos mismos. De hecho, es en este sentido que he planteado la cuestión de literatura escrita sobre los negros versus literatura escrita por los negros. Es decir, no en términos antagonistas, sino a partir de un espíritu de cooperación.

En cuanto a la situación particular de los negros frente a cualquier intento de minimizar su africanidad, por un lado, y de deslegitimar sus reclamos raciales, por otro, al leer a tales escritores como a René Depestre y a Henry Louis Gates, Jr., por ejemplo, se reciben perspectivas enriquecedoras que hacen posible una profundización de lo que se sabe de los negros y de los demás. De nuevo, en vez de un temido separatismo que amenace con desmembrar la nación, se desprende del pensamiento afrocéntrico la noción de una coexistencia conflictiva de grupos diversos que inevitablemente se influyen los unos a los otros. Según ha escrito Depestre:

[...] el hombre africano, deportado a las Américas o colonizado, ha sido obligado por las circunstancias, con sus riesgos y peligros, a formarse una conciencia racial. Esta conciencia se le ha producido, no porque tuviera, desde tiempos inmemoriales, un $<<$ alma negra $>>$, o una $<<$ negritud $>>$ consustancial a su $<<$ naturaleza $>>$, sino más bien a causa de las especificidades coloniales de la economía mercantil. La situación de los africanos esclavizados o colonizados se definió por las circunstancias americanas (el sistema de plantación) de un modo preciso de producción y de distribución de los bienes.
La conciencia racial fue impuesta a los trabajadores de las plantaciones por las estructuras estrictamente fechadas de la historia de la esclavitud y de la colonización. (113)

Por su parte, Gates ha constatado:

La noción de que la trata de esclavos fue tan traumática y que funcionó para crear en el africano una conciencia propia de alguna tabula rasa, es tan extraña como lo es una ficción, una ficción que ha servido a varios órdenes económicos y sus ideologías correspondientes. La completa eliminación de los rastros de culturas tan espléndidas, tan antiguas [...]

como las culturas clásicas de la tradicional Africa Occidental hubiera sido extraordinariamente difícil.

[...] Inadvertidamente, la esclavitud africana en el Nuevo Mundo cumplió con las precondiciones para la emergencia de una nueva cultura africana, una cultura verdaderamente pan-africana fabricada como un encaje lleno de colorido de hilos lingüísticos, institucionales, metafísicos y formales. [... ] La cultura afroamericana es una cultura africana con una diferencia determinada por los catalizadores que eran las lenguas y culturas inglesas, holandesas, francesas, portuguesas o españolas que influyeron en las estructuras precisas que cada cultura panafricana del Nuevo Mundo asumió. (The Signifying Monkey 4; traducción mía)

Lejos de todo concepto esencialista acerca de los negros, tanto Depestre como Gates demuestran cómo la negritud ha si- 
do (y sigue siendo) un "llegar a ser" dentro de la historia. A diferencia de muchos estereotipos que han sido empleados con demasiada frecuencia para presentar a los negros como un conglomerado estático y uniforme de gente, la visión histórica que se patentiza en los comentarios de Depestre y Gates resalta la complejidad de la interacción entre los negros y los no-negros. $\mathrm{Al}$ mismo tiempo, sugiere la gran diversidad característica de la diáspora. Por eso, Césaire se vio obligado a advertir: "Si la negritud consiste en vaticinar, pues bien no, porque yo creo [...] que existe la lucha de clases, que hay otros elementos, que hay elementos filosóficos, etc. que deben determinarnos. Yo $[\ldots]$ me niego totalmente a considerarme, en nombre de la negritud, el hermano del Sr. François Duvalier" (en Depestre 104).

Mis referencias continuas a la "convivencia," a la "co-participación" y al "diálogo" ponen de relieve la necesidad de superar esquemas polarizados al tratar las diferencias de cualquier sociedad. De hecho, la manera misma en que he planteado el problema de una literatura escrita sobre los negros versus una literatura escrita por los negros sería un equívoco en la medida en que sugiriera una rígida antítesis de propósitos y perspectivas. En vez de expresarme en términos de una relación de "versus," tal vez hubiera sido preferible emplear una frase como "junto a" para, así, evitar posibles dualismos que pudieran contradecir los fundamentos de mi análisis. La larga tradición del racismoconsciente o inconsciente-, sin embargo, todavía requiere estrategias capaces de combatir todo intento de diluir la presencia vital de los negros en sus sociedades respectivas. Por eso, más que proponer una polaridad de expresiones literarias, he utilizado el "versus" como una voz de alerta ante las tendencias de silenciar a las minorías o a otros grupos sin poder. ${ }^{7}$

El afrocentrismo es por lo tanto un modelo crítico que puede ayudar a establecer un equilibrio conceptual en la revisión de la identidad nacional en sociedades multiculturales o plurinacionales. El esquema propuesto por Ralph Ellison y, el que Henry Louis Gates, Jr., ha recogido, por ejemplo, me parece sugerente. Según recuerda Gates, con el árbol literario que Ellison había imaginado como una representación de su genealogía familiar, él hizo una distinción entre sus antecedentes negros, a quienes había clasificado como parientes, y sus ancestros que eran blancos. Este paradigma constituía "una importante revisión conceptual sobre aquellas influencias" simbolizadas por dichos parientes y ancestros "puesto que sus ancestros ofrecían textos modelos para revisar, mientras que sus parientes compartían con él temas comunes. [...] Varios de los textos canónicos de la tradición afroamericana parecen estar relacionados a otros textos negros primordialmente por su sustancia o su contenido, al mismo tiempo que parecen estar relacionados a textos occidentales por la forma" (Gates, The Signifying Monkey, 121-122; traducción mía).

¿No tendrán los no-negros un árbol genealógico similar? Una posible respuesta se encuentra en un comentario de René 
Depestre quien ha identificado la negritud "'con un créolité esencial del Caribe y de América.' Ser 'americano' es ser híbrido, métis, y según la visión de Depestre, los verdaderos herederos de la negritud han sido escritores como Carpentier, Guillén, Amado, Vallejo, Cortázar, Márquez. De nuevo, la negritud es transmutada; ya no es una cuestión de raíces, sino de un proceso actual en una realidad polifónica" (Clifford 179). Como espero demostrar a continuación, los miembros del Grupo de Guayaquil también fueron influidos por una herencia negra, aunque a veces más intuida que comprendida.

\section{El Grupo de Guayaquil y la función de los personajes negros}

Aunque se encuentra a gente negra en todo el Ecuador, es en la Costa donde su presencia realmente se hace sentir. ${ }^{8}$ De hecho, en Crónicas del Guayaquil antiguo, Modesto Chávez Franco escribió:

Ellos construyeron nuestros fuertes, combatieron con los piratas, apagaron nuestros incendios, cargaron a nuestros apestados, barrieron y pavimentaron las calles, hicieron la luz o las tinieblas en nuestras silentes o tempestuosas noches coloniales; fueron soldados; y en sus ocios y en sus noches se dieron tiempo para dejarnos sus bailes, sus cantos y su música con que $[\ldots]$ rememoraban sus ya confusos recuerdos y añoranzas de su vida libre en las selvas africanas. (181)

De diversas maneras, este mismo reconocimiento de la participación de los negros en la vida costeña permea las obras escritas por los integrantes del Grupo de Guayaquil. De hecho, la incorporación del negro en la literatura representa uno de los aspectos que distingue las letras de la Costa de las de la Sierra. Pero, a pesar de su inclusión en las obras del Grupo de Guayaquil, el personaje negro no constituía una expresión de negritud o de lo afro, por lo menos en términos culturales e históricos más allá de la denuncia social o de lo exótico y lo primitivo. Por eso, los personajes negros del Grupo de Guayaquil no llegaron a ser afroecuatorianos, propiamente; los comentarios ya citados de Demetrio Aguilera Malta y Juan García Salazar ayudan a explicar la diferencia de perspectivas acerca de lo racial, una diferencia que sigue condicionando el debate sobre la identidad nacional/plurinacional del Ecuador.

Baldomera, Alfredo Baldeón, Masa Blanca y Bulu-Bulu son, indudablemente, algunos de los personajes negros más memorables de la ficción del Grupo de Guayaquil y, al mismo tiempo, revelan la medida en que la caracterización simbólica puede opacar y desarticular (aunque sea inconscientemente) la problemática de ser negro en el Ecuador. Los cuatro personajes caben dentro de dos tradiciones: el negro como vehículo de la protesta social y el negro como encarnación de lo mágico, máxima expresión de la "otredad." En cuanto a Baldomera y Alfredo Baldeón, ${ }^{9}$ cuya función principal dentro del realismo social de los años 30 fue la de representar las injusticias sufridas por el pueblo ecuatoriano, el concepto de raza que les dio forma parece haberse expresado clara- 
mente en Las cruces sobre el agua. Al volver a Guayaquil, Baldeón descubrió que el padre, quien era originalmente de la Sierra y no era negro, había perdido su panadería. En este momento del texto, el narrador se refirió al padre y a Alfonso, el amigo de Baldeón, para explicar:

Actualmente es que era de veras un hombre. Y era pueblo: nada quería con blancos y ricos. ¿Y Alfonso? ¿Acaso era blanco? Esa palabra blanco era una palabra zonza: ricachones de jeta habían (sic), a los que se les llamaba así. En Guayaquil ser blanco es tener plata. Su padre era más blanco que cualquier gamonal. Y Alfonso Cortés era pobre tanto como Alfredo, y carecía de presunciones y era hombre de verdad. (175)

En efecto, lo racial se presentaba sobre todo como un componente de la lucha económica, una lucha de blancos contra el resto del pueblo, de aquellos con poder contra los oprimidos.

La dicotomía racial como expresión de las relaciones del poder revela, sin embargo, un racismo latente y traicionero que confunde la denuncia y la admiración, el rechazo y la aceptación de lo supuestamente especial (¿la superioridad?) de los blancos. En este sentido, se comprende que el tema de la raza implica mucho más que lo económico. Es así que, de niño, Alfredo sentía una fascinación casi idólatra por una mujer blanca, la cual era como su angel de la guarda.

Jamás había conocido una persona igual. No sabía que existieran. Era una mujer blanca, era como si su madre fuera blanca. Se parecía a la estampa de la virgen que había colgada, junto a un pequeño espejo, en las cañas de la pared de un rincón de su cuarto.

[...] La mano que le había puesto sobre la cabeza era rosada y su olor, de suave, lo atontaba. (24)

Además, "Alfredo se acordaba de la blanca a todas horas" (27). De manera que, pese a lo prevaleciente del enfoque económico, se puede leer la inocencia del niño Alfredo en cuanto a la blanca como una amplificación tácita de lo racial, llevándolo a una dimensión psicológica y sociocultural y, como tal, poniendo en tela de juicio aquella aseveración ya citada de Aguilera Malta de que podría existir la discriminación racial sin haber un problema racial en el Ecuador. ${ }^{10}$

Por supuesto, lo de "problema" es muy relativo y su definición se presta a muchas interpretaciones. Aunque Las cruces sobre el agua trataba de la masacre en que murieron huelguistas y manifestantes en Guayaquil el 15 de noviembre de 1922, por una parte, y de las condiciones socioeconómicas que paulatinamente causaron la tragedia, por otra, no se debe leer la novela en blanco(s) y negro(s). Es decir, a pesar de una evidente denuncia, hace falta tener en cuenta que Alfredo Baldeón era zambo y, en cierta manera, su condición mixta sugería ciertas ambivalencias y contradicciones relacionadas a la presencia del negro en el Ecuador, pero no desde el 
interior del personaje, sino desde su recepción/interpretación, tanto por el escritor como por los lectores.

Referencias textuales a la guerra de Carlos Concha en Esmeraldas dieron lugar a una protesta dirigida específicamente contra la explotación sufrida por los negros: ${ }^{11}$

El negro es negro para que trabaje y para patearlo; la negra es negra para tumbarla y hacerle un mulato. Eran esclavos antes. ¿Y acaso habían dejado de serlo? ¿No los metían al cepo? ¿No los golpeaban hasta matar, si en el puerto se negaban a vender su tagua al precio que a ellos les daba la gana? Hoy les enseñaban de filo los ojos, los dientes y los machetes. Era su hora. (59)

Curiosamente, la decisión de Alfredo de unirse a los conchistas tenía muy poco que ver con una conciencia de ser negro. Más bien, Alfredo se fue para Esmeraldas porque estaba aburrido: "Alfredo avisaba al taita que se iba a la guerra, a pelear del lado de los negros y por su propio gusto; que estaba harto de la escuela; que regresaría con plata y hecho militar" (52). Aunque hay alguna que otra referencia a "la sangre zamba que le venía de la madre" (61), en un sentido cultural o étnico, la condición de ser negro parece accidental. Alfredo era un vocero de todos los explotados y, por lo tanto, si fuera cholo en vez de zambo, ni el personaje ni la novela habrían sufrido mayores cambios. Por eso se lee: "Me he convencido de una cosa, ¡carajo! ¡mientras quede uno solo teniendo hambre, todos tendremos hambre!
Convéncete vos hermano" (195). Y al final de la novela, años después de la masacre, Alfonso regresó a Guayaquil para constatar:

No debía ser sólo Guayaquil la que seguía igual. En los calientes campos costeños, los hacendados y la Rural continuarían manteniendo a balazos la esclavitud de los montuvios, y más adentro, en la sierra, el acial caería siempre, monótono, inacabable, sobre las espaldas de los indios. (244)

En Las cruces sobre el agua, Gallegos Lara retomó uno de los momentos más trascendentes de la historia moderna del Ecuador para denunciar las injusticias de un sistema capitalista caracterizado por una rígida jerarquización social de clases. Una de las funciones principales de Alfredo Baldeón fue la de representar a toda la gente de color, a los oprimidos y explotados, al pueblo sufrido. La condición de ser zambo colocaba a Alfredo en una posición de representatividad ejemplar puesto que las "impurezas" de su mezcla simbolizaban el potencial de consolidar las diferencias de la nación frente a una tradición exclusivista de "purezas" arbitrarias y sus correspondientes privilegios.

En el prólogo a las Obras escogidas de Gallegos Lara, Miguel Donoso Pareja ha advertido, con mucha razón, que Las cruces sobre el agua no debe leerse solamente como "la novela de la matanza del quince de noviembre' [...], minimizando su proyección y la de la propia masacre [...]" (9). Hay que tomar en cuenta que la novela "maneja y combina cuatro focos de significación básicos: la ciudad, las accio- 
nes de los protagonistas, la búsqueda de una identidad y la interpretación política de los acontecimientos" (13). Además, según el mismo Donoso Pareja,

Baldeón y Cortés son amigos del barrio, pero de diferentes extracciones sociales, el primero proletario, el segundo de la pequeña burguesía, el primero un trabajador manual, el segundo un intelectual pequeño burgués. Ambos andan en busca de una conciencia y de una identidad, inmersos en las contradicciones que [...] se manifiestan en diversas expresiones, frecuentes a lo largo de toda la novela [...]. (14-15).

En efecto, el tipo de lectura comprehensiva que pide Donoso Pareja invita a considerar lo racial como un elemento fundamental dentro de aquella búsqueda de "una conciencia y de una identidad."

Si bien es cierto que la raza de Baldeón no se ha leído tradicionalmente como una preocupación central de la novela, es también cierto que Gallegos Lara había insertado en el texto suficientes referencias que se prestan a nuevas reflexiones, especialmente en vista de las propuestas afrocéntricas comentadas en páginas anteriores. En cierta manera, el tema de la condición racial de Baldeón, símbolo del pueblo, ha quedado sin resolución ante la urgencia de la lucha mayor y común a todos los explotados. En el Ecuador, serán los escritores que se identifican como afroecuatorianos que llevarán el tema de la negritud con todos sus matices raciales a un contexto afrocéntrico en el cual se comprenderá que "el hombre negro colo- nizado no sólo vive, como todo proletario, la opresión en el hecho de vender su fuerza de trabajo en el mercado capitalista, sino que la vive al mismo tiempo, con igual intensidad, en su singularidad epidérmica. El es explotado como proletario y como hombre de piel negra" (Depestre 48).

Para los propósitos de este estudio, Las cruces sobre el agua se destaca por constituir una expresión metonímica de la situación de los negros en el Ecuador. Aunque se reconoce su presencia, celebrándola a menudo con proporciones heróicas, todavía muchos ecuatorianos se resisten a aceptar lo afro como un factor determinante de identidad que corresponde a tradiciones y fuerzas histórico-culturales independientes de un mestizaje diluido o de un pueblo de explotados anónimos. En efecto, para lograr la lectura totalizadora que Donoso Pareja ha propuesto, hará falta una nueva visión capaz de abordar tanto lo económico como lo racial al valorar las múltiples identidades que componen al Ecuador.

El personaje que más ilustra el vacío que existe entre el reconocimiento superficial del negro, relegándolo a lo simbólico o a lo pintoresco, y el examen problematizador de lo que significa ser negro frente a su historia particular como negro es Baldomera. El sitial que ella ocupa entre las figuras más queridas de la ficción ecuatoriana se patentiza al leer la opinión de Hernán Rodríguez Castelo: “Baldomera merece un lugar especial en el realismo social ecuatoriano por su personaje, impresionante tipo de mujer mulata costeña" 
(9). Lo que interesa de lo citado es la referencia a la mulatez, un marcador que no va más allá de lo físico. Como fue el caso de Alfredo Baldeón, la mulatez de Baldomera la convertía en el símbolo de los marginados frente a los explotadores que, en su mayoría, se consideraban blancos. Esta dicotomía le sirvió a Pareja Diezcanseco como base conceptual en la estructuración de su denuncia contra las injusticias sufridas por el pueblo durante la misma época tratada por Gallegos Lara en Las cruces sobre el agua. Pero, a diferencia de su compañero de generación que empleó algunos referentes histórico-culturales que abrirían la posibilidad de contextualizar (aunque fuera de una manera incipiente) la mulatez/negritud del personaje central, ${ }^{12}$ Pareja Diezcanseco dejó a su personaje en un plano simbólico, insistiendo sobre todo en su condición física descomunal y en su espíritu rebelde. ${ }^{13}$

Desde la primera descripción de Baldomera, se vislumbra una ambivalencia que marcará profundamente la concepción y la recepción del personaje. Según el texto:

Es Baldomera una mujer todavía joven.... Sentada, se la ve mediana. Pero si Baldomera se levanta, hay que ver. Parece tener más de un metro ochenta de estatura, aunque, en verdad, no tenga más de los setenta o setenta y cinco.... Viéndola un poco lejos, y en sombras, se apostaría que no tiene barba. Pero, no. Es inconfundible: sus pelos.... Además, Baldomera es negra. No tanto. Tiene más bien un ligero tinte violáceo. (9-10)
Sencillamente, Baldomera no es lo que parece ser. Además, hay que comprender que las repetidas advertencias del narrador de mirarla más de cerca trascienden el plano puramente físico/descriptivo. Todos sus rasgos, comportamientos y valores supuestamente nuevos encontrados al principio de la novela no son más que aberraciones momentáneas. Es decir, sus primeros visos de ser una mujer independiente, rebelde y mulata terminan siendo solamente elementos de color local ya que la intención fundamental de Pareja ha sido la de hacer una denuncia genérica contra la explotación sufrida por las clases pobres de la ciudad y no por las mujeres o mulatas, específicamente.

La primera descripción citada arriba también revela un concepto de raza que implícitamente le niega al negro complejidad ya que se lo define principalmente en términos del color de piel y, en el proceso, se lo descontextualiza de varios siglos de historia. Esta simplificación es preocupante puesto que ha habido (hay) muchas Baldomeras en la sociedad ecuatoriana cuyas experiencias han sido profundamente afectadas por su condición racial. De hecho, Pareja mismo ha comentado el origen de su personaje: "Mi suegra me contó sobre Baldomera que nació en las barriadas; una mujer borracha, que se peleaba a puñetazo limpio y que participó en los hechos que culminaron el 15 de noviembre de 1922" (Febres Cordero 102). $\mathrm{Al}$ mismo tiempo, Pareja parece haber revelado la honda impresión que las mujeres trabajadoras de color habían dejado en él 
cuando evocó algunos de los recuerdos especiales de su infancia en Guayaquil: "En mi infancia [Guayaquil] no debe haber tenido más de setenta mil habitantes.... Y las negras, las mestizas y mulatas con sus charolas en la cabeza vendiendo tamalitos" (Febres Cordero 114).

Desgraciadamente, el contacto que Pareja tuvo con estas mujeres no fue suficientemente profundo para evitar los estereotipos y cierta tendencia a folklorizarlas. De hecho, la caracterización que Pareja le dio a Baldomera representaba un cruce de aquellos dos estereotipos primordiales que Susan A. Soeiro ha puesto de relieve:

La mujer latinoamericana, la del pasado y la del presente, según la hemos conocido, es inconfundible por sus cualidades de mujer virtuosa que detesta el sexo y adora a su familia: una esposa sumisa y madre cariñosa, cómodamente segura en su domesticidad y devoción a los niños, la iglesia y la cocina. Un estereotipo complementario es el de la mulata frívola, tentadora y promiscua. Por supuesto, estas formas de comportamiento son ideales y no necesariamente normativas. [.. ] Estas imágenes tienen poco que ver con la realidad afrontada por una multitud de mujeres latinoamericanas. (497-498; traducción mía)

Además, la superficialidad con que se ha tratado la mulatez de Baldomera parece haber opacado la presencia histórica de muchas mujeres mulatas que vivían en Guayaquil desde la época colonial y que jugaban papeles sociales dinámicos a pesar de un sinnúmero de obstáculos socioeconómicos y políticos con raíces en la es- clavitud. ${ }^{14}$

Vuelvo a insistir en las ventajas (¿la necesidad?) de leer textos como Baldome$r a$ desde una perspectiva afrocéntrica. Las preguntas que el afrocentrismo despierta sobre la verosimilitud de los personajes y la perspicacia de las interpretaciones que se hacen acerca de las relaciones interraciales captadas en cada texto prometen llevar las lecturas a nuevos niveles de comprensión. Más que un accidente biológico, la raza supone vivencias culturales que se han desarrollado conscientemente frente a diversas circunstancias sociohistóricas $y$, por lo tanto, hacen falta más atención y sensibilidad frente a lo que significa ser negro. Estos reparos no han de quitarle a Pareja Diezcanseco, por ejemplo, sus grandes méritos como escritor, historiador, diplomático y defensor acérrimo de los derechos humanos. Pero, como todos, él tampoco pudo eludir por completo la miopía cultural de su época. En este sentido, nuevas lecturas de las obras clásicas constituyen una necesaria revisión de muchos de aquellos criterios y presupuestos que han deformado la dilucidación general de la literatura y las sociedades en las que se ha escrito. En efecto, para grupos tradicionalmente marginados y poco comprendidos fuera de los esquemas inventados por diversos sectores hegemónicos, la revisión mencionada sugiere un imperativo similar al que Adrienne Rich planteó desde una perspectiva feminista:

Re-visión-el acto de mirar atrás, de ver con ojos nuevos, de entrar en un viejo texto desde un nuevo ángulo crítico-es 
para nosotras más que un capítulo de la historia cultural: es un acto de supervivencia. Hasta que comprendamos las suposiciones en que estamos empapadas, no podremos conocernos a nosotras mismas. [...] Una crítica radical de la literatura [...] consideraría la obra, sobre todo, como una clave de cómo vivimos, de cómo hemos estado viviendo, de cómo se nos ha enseñado a imaginarnos, de cómo nuestro lenguaje nos ha atrapado $y$, también, de cómo nos ha liberado; y de cómo podemos comenzar a ver- $y$, por consiguiente, a vivir-nuevamente. [...] Necesitamos conocer la escritura del pasado, $y$ conocerla de maneras hasta ahora no imaginadas; no para transmitir una tradición, sino para romper su dominio sobre nosotras. (124-125; traducción mía)

Sin duda alguna, parte del proceso de liberación que Rich evocó en la cita de arriba ha de incluir la superación de aquellos estereotipos que son aceptados irreflexiva y ciegamente con menoscabo de los grupos afectados. Una de las imágenes que más ha influido a los lectores ha sido la del brujo y guardián de ciertos secretos maléficos o prohibidos de la naturaleza. Masa Blanca, una creación de José de la Cuadra, y el Bulu-Bulu de Aguilera Malta ejemplifican al negro como una fuerza primitiva que no pertenece realmente al mundo de los civilizados. Es de notar lo variable que son las referencias a la negritud, según los propósitos de cada autor al caracterizar a sus personajes negros. Cuando predomina un afán integracionista, lo negro se identifica más que nada como el color de piel, sin ningún referente cultural (como en el caso de Baldomera); al otro extremo se encuentra al personaje negro arraigado en tradiciones supuestamente africanas y ajenas a la experiencia general de los lectores (como son los casos de Masa Blanca y Bulu-Bulu). El exagerado interés en lo negro como símbolo de los misterios de la naturaleza puede producir la misma negación de vivencias y valores que resalté al comentar Las cruces sobre el agua y Baldome$r a$. Mientras que en el primer grupo se niegan vínculos con una historia particular, el retrato unidimensional del brujo, por ejemplo, puede negarle la complejidad y universalidad que caracterizan a todo ser humano. ${ }^{15}$

Al tomar en cuenta el afrocentrismo que ha puesto en tela de juicio la verosimilitud y la representividad de muchos de estos perso infranqueables. Lógicamente, no se trata aquí de responsabilizar a los escritores por las lecturas que se hacen de sus obras. De hecho, en lo que respecta a Aguilera Malta y de la Cuadra, una sensibilidad afrocéntrica ayuda a ver más allá de las superficialidades comunes para, así, descubrir posibles claves en el texto que subvierten algunos de los estereotipos perjudiciales que tanto se ha criticado. En el caso de Bulu-Bulu, por ejemplo, mientras que su mundo mágico predomina en Siete lunas y siete serpientes (1970), creando "la dimensión primitiva de la novela" (Fama 111) y constatando que el brujo "tiene una existencia que trasciende las leyes temporales" (Fama 101), el lector cuidadoso no perderá de vista las referencias 
a los prejuicios raciales y a la esclavitud. Es decir, inmerso en un texto mítico donde sería fácil reducir a la gente negra a la otredad por su asociación aparente con el brujo-y con todas las connotaciones que éste lleva-, se encuentran indicios de una existencia más compleja que oscila entre lo mítico y lo histórico. ${ }^{16}$

Masa Blanca también desafía interpretaciones demasiado rígidas y reduccionistas. En Los monos enloquecidos (1931), se lee que él era de Africa y "Lo menos que decían era que el negro curandero sería Satanás o un enviado suyo [...]" (159). Aunque la otredad, el misterio y lo diabólico son las rasgos más patentes del personaje, hay que recordar que Cuadra era un maestro de la creación irónica y, por lo tanto, es de notar que el brujo revelaba cualidades y vicios muy humanos; era vanidoso, presuntuoso y "profundamente ambicioso, y su ambición rayaba en la avaricia" (143). En fin, Masa Blanca era un aprovechador, por no decir farsante. De hecho, en el cuento, "La Tigra" (1935), el mismo Masa Blanca oportunista empleaba su fama de brujo para engañar a las hermanas Miranda, supersticiosas e ingenuas ante los misterios de lo desconocido. $\mathrm{Al}$ acercarse al brujo para pedirle la protección, Masa Blanca "pensó en el negocio.... Pero, mi precio es una vaca rejera... con er chimbote claro" (174). Luego de llevar a cabo una "misa mala" donde "se movía como un verdadero poseído" (174), la Tigra quería que él asegurara que el diablo no regresara nunca más a su hogar:
— ¿No s’apoderará otra vez de la casa el Compadre?

Masa Blanca vaciló al responder:

-Puede de que no, si hacen lo que yo digo...

Otro negocio. Cerrado el asunto, el hechicero habló pausadamente. Era visible que le costaba dificultad inventar $<<$ la contra $>>$; pero, las Miranda no se percataron de ello. (175)

Este retrato de Masa Blanca encaja perfectamente bien en el proyecto desmitificador que caracteriza la obra de Cuadra. Humberto Robles ha señalado:

Es en vista de características atribuidas al montuvio como "la tendencia mítica," el panteismo que "se manifiesta en la creencia... de poderes protectores," la "fabricación de héroes" y en vista de su condición de "secular explotado" que habría que leer obras de madurez como "La Tigra,".... Esa lectura recalcaría que en la poética de Cuadra se ha afincado una mayor conciencia social...; que el interés en la elaboración literaria del proceso mitopoético, llevado a un máximo refinamiento en...["La Tigra"], se le ha anudado una preocupación igualmente importante: la urgencia y necesidad de desmitificar esa realidad fabulosa. El alegato social vendría a ser el otro filón constitutivo de su producción narrativa. ("De la escritura a la oralidad..." 77)

Aunque se puede seguir interpretando al brujo desmitificado estrictamente en términos negativos, afincando aún 
más ciertos estereotipos racistas empleados para marginar y excluir a los negros de la sociedad oficial, la propuesta de Cuadra apuntaba hacia otro fin. Al deconstruir a Masa Blanca, Cuadra no solamente subvertía toda una historia de supersticiones, sino que desmantelaba el estereotipo mismo del brujo negro malévolo, poniendo de relieve la viveza y la astucia del personaje negro que sabía manipular los defectos y las debilidades de los demás. Esta última observación no pretende justificar maldades y engaños de parte de nadie; más bien, destaca la complejidad de la caracterización de algunos personajes negros de la literatura ecuatoriana y, al mismo tiempo, reclama lecturas creativas capaces de romper moldes anacrónicos para, así, entender mejor algunas de las dinámicas que todavía condicionan las relaciones entre las razas.

El Grupo de Guayaquil y la gestación de un nuevo concepto de los personajes negros

En cierta manera, la confluencia de usos simbólicos del personaje negro y un aparente cuestionamiento de estereotipos tradicionales mediante referencias históricas o procesos desmitificadores revela una búsqueda de identidad costeña que, por lo menos, se intuía en pugna con el mestizaje oficial de la nación. Humberto Robles ha puntualizado que "el carácter conflictivo del asunto raza no se limita al ámbito del cholo, a la oposición entre lo indio y lo español, como parece sugerir Icaza [...], sino que incluye el del mulato [...]" ("Reseña sobre El Chulla Romero y Flores"
721). Es así que no se ha de olvidar el giro irónico que Cuadra le dio al contexto en que Nicasio Sangurima se jactaba de ser "hijo de gringo" (Los Sangurimas 41):

Las canas estaban ausentes de esa mata de hilos ensortijados. Por ahí, en esa ausencia, denotaba su presencia remota la raza de Africa.

Pero don Nicasio lo entendió de otra manera:

- ¿Pa qué canas? Las tuve de chico. Ahora no. Yo soy, de madera incorruptible. Guachapelí, a lo menos. (41-42)

La explicación de Nicasio Sangurima no solamente sugiere una negación de raíces negras que siguen resistiendo todo intento de eliminarlas/mestizarlas/blanquearlas, sino que indica la medida en que algunos de los escritores del Grupo de Guayaquil reconocieron en lo negro un problema por exponerse. En este sentido creo que Dientes blancos (1955) e Infierno negro (1967) de Aguilera Malta, Los monos enloquecidos (1931) de José de la Cuadra y "El negro Santander" (1933) de Enrique Gil Gilbert constituyen un corpus de material en que se asentaron las bases para la gradual (e irregular) incorporación del negro en el imaginario plurinacional del Ecuador. Concretamente, mediante el enfoque internacionalista de Aguilera Malta, la parodización de la esclavitud nacional en Cuadra y la construcción de una historia nacional con la presencia medular del negro tan patente en Gil Gilbert, se puede rescatar un proyecto dirigido contra el racismo cuya existencia tanto se ha negado 
en nombre del ya mentado mestizaje nacional.

\section{A. Demetrio Aguilera Malta}

Aguilera Malta representa el caso más problemático de los tres autores mencionados arriba; de hecho, su perspectiva internacional puede interpretarse como una negación más del "problema racial" en el Ecuador, concretamente. Es de notar que ningún otro escritor no-afroecuatoriano ha tratado tan extensa y frontalmente la discriminación racial contra los negros como Aguilera Malta. Sin embargo, lo que llama la atención es cómo su solidaridad para con los negros no ha podido evitar ciertas contradicciones y equivocaciones, tanto de parte suya como de la de muchos de sus lectores. ${ }^{17}$

A manera de ilustración de lo problemático de las contribuciones de Aguilera Malta (y de su recepción), me remito a los siguientes comentarios de Clementine Rabassa, Gerardo Luzuriaga y del mismo Aguilera Malta. Según Rabassa, Aguilera Malta

Es uno de los pocos autores de Hispanoamérica que distinguen entre lo pintoresco o folklórico y lo humano y verdadero para recrear la realidad negra tal como era, como es, y como será. Infatigable observador, ha estudiado al hombre de color en muchos contextos sociológicos y literarios [...]. Por ser humanista [...] revela su afinidad de profundizar y comunicar el espíritu negro desde sus primeras novelas. (112)
En una entrevista con Rabassa, Aguilera Malta insistió:

[...] en algunos de nuestros países donde tenemos minorías negras, el porcentaje de ellas es tan pequeño que realmente no significan un problema de importancia. Pero esto es algo diferente de la discriminación. La discriminación, sí existe. [...]

En Ecuador las minorías negras casi no constituyen problema. (en Rabassa 116)

Luego, Aguilera Malta continuó aseverando que

Con todo, para mí la gran diferencia, la diferencia más negativa para los negros de América Latina, es que mientras en Estados Unidos se advierte un espíritu de raza, de autodefensa y de "negritud," [...] entre nosotros las gentes de color están bastante desunidas y muchas cifran más bien su conquista en ser menos negras, en mezclarse con los blancos, en asimilarse a éstos en todo. Es galardón. En EE.UU. el negro quiere ser negro y defender todas las virtudes esenciales de su raza. (en Rabassa 117)

Y, finalmente, un importante estudioso de la obra de Aguilera Malta ha concluido que "el tema de la discriminación contra la raza negra, presente ya en Dientes blancos [...] podría parecer extraño en la pluma de Aguilera Malta, por tratarse de un problema casi inexistente en su país de origen" (Luzuriaga 135).

Desde un punto de vista afrocéntrico, hay mucho que objetar a lo citado. A 
pesar de las buenas intenciones de Aguilera Malta, es imposible aceptar la noción de que él pudiera haber recreado "la realidad negra tal como era, como es, y como será." Tal comentario peca de paternalista y colonialista ya que a los negros mismos les competerá semejante recreación, especialmente en lo que respecta a su futuro. Además, la referencia que hace Rabassa a "profundizar y comunicar el espíritu negro" presupone un esencialismo rancio que niega la gran diversidad que caracteriza tanto a los negros como a los de cualquier otro grupo humano.

En cuanto a los comentarios hechos por Aguilera Malta, sorprende que él haya medido la importancia de un problema mayormente en términos del número de la población afectada. Como se verá más adelante, especialmente en el capítulo VII ("Del mestizaje al 'Proceso de Comunidades Negras': Reflexiones sobre la evolución de una política afrocéntrica en el Ecuador"), hace varios siglos que los negros del Ecuador luchan por defender su identidad afroecuatoriana frente a innumerables obstáculos (económicos, políticos, educacionales, culturales) y, por consiguiente, el concepto de la magnitud del "problema" resulta profundamente relativo. También, sorprende que Aguilera Malta haya minimizado la gravedad de aquel deseo de muchos negros de blanquearse, describiéndolo como una "diferencia [...] negativa," pero sin haberlo comprendido como una importante manifestación del "problema" racial. De igual modo, Aguilera Malta se equivoca cuando acepta la idea estereotípica de un supuesto abismo cultural entre el pueblo negro norteamericano y los del resto de América, incluyendo el del Ecuador. Ya se sabe que hubo mucha comunicación entre los intelectuales negros de todo el continente, especialmente a partir del surgimiento del Harlem Renaissance y el afrocriollismo del siglo XX. En efecto, a pesar de las obvias diferencias "nacionales," la experiencia racial a través de toda la diáspora ha producido una larga tradición de pueblos negros que han querido "defender todas las virtudes esenciales de su raza." De hecho, esta defensa constituye un aspecto medular de lo que significa ser afroecuatoriano en un país donde se sigue combatiendo la negritud con el silencio, la indiferencia y otras formas ríspidas de negación.

Estos reparos sirven para sacar a la luz las múltiples manifestaciones del "problema racial," algunas más sutiles que otras. En cuanto a la literatura como un proceso en el cual se han creado no pocas de las principales imágenes que muchos tienen de los negros, vale recordar el predominio de la imaginación de los escritores/lectores blanco-mestizos. Una observación instructiva al respecto es la que hizo Toni Morrison al constatar que "hasta muy recientemente, y pese a la raza del autor, se ha dado por sentado que los lectores de casi toda la ficción [norte] americana han sido blancos. Me interesa saber qué ha significado esa suposición para la imaginación literaria" (xii; traducción mía). A estas alturas, el paralelo entre el caso estadounidense (según lo ha planteado Mo- 
rrison) y el latinoamericano (y el ecuatoriano, más concretamente) debe ser obvio. Con demasiada frecuencia ha habido una apropiación de las experiencias de los negros mediante la cual se ha confundido autoría con autoridad, interpretación con verdad. Las distorsiones inevitables de esta apropiación salen a flor de piel cuando Richard Jackson explica:

La poesía negra, entonces, gran parte de ella falsa, se extendió por el Caribe y América del Sur, y, como en EE.UU. y en Euro$\mathrm{pa}$, los negros se convirtieron en una atracción principal de teatro, donde el blanco-y algunos negros, también-hicieron que el negro actuara como títere, hasta que el cubano, Regino Pedroso, un poeta de color, entró con su famoso poema, "Hermano negro," y le dijo al bailarín, "apaga un poco tus maracas," para que dejara de tocar tanto las maracas, para que dejara de sonreír, de bailar y de saltar para el blanco. Le dijo a su hermano negro que diera al mundo más bien su voz de rebeldía, su voz humana. (The Black Image in Latin American Literature 44; traducción mía)

En efecto, al leer a Aguilera Malta y la crítica que se ha escrito sobre su obra, no se encontrará "la voz" de los negros, sino una interpretación parcial e incompleta, aunque también, honesta y solidaria. El mismo ha definido su acercamiento al mundo negro en los términos nobles de combatir irrevocablemente la discriminación racial. Pero, en el proceso de la creación y su correspondiente recepción, el yo-acuso ha opacado otras posibles interpretaciones del mundo negro, tanto en el Ecuador como en el resto de la diáspora.

La obra dramática, Dientes blancos, ejemplifica la medida en que la denuncia puede alejar a los lectores de una verdadera aprehensión de las complejidades (la humanidad, diría Jackson) de lo que significa ser negro en el mundo. De lo mucho que se ha comentado sobre esta obra, se vislumbra una tendencia de ubicarla en un contexto general de protesta para, así, garantizar su importancia. Es decir, consciente o inconscientemente, parece que se ha sentido la necesidad de resaltar su cualidad supuestamente simbólica ya que aquella "imaginación literaria" predominantemente blanco-mestiza comentada arriba sigue relegando a los negros a la otredad y, por lo tanto, una plena identificación con ellos como seres humanos (en vez de como símbolos) es todavía elusiva.

Es en ese contexto simbólico ( $y$ deshumanizante) que Aguilera Malta ha señalado que "El problema racial no es sólo el de la raza negra [...]" (Luzuriaga 201); $y$, por su parte, el crítico Luzuriaga ha puntualizado que "Dientes blancos se convierte, excediendo la denuncia de injusticias raciales, en un grito de acusación contra las clases dominantes opresoras que de múltiples maneras intentan sojuzgar al hombre, arrebatándole su dignidad y sus derechos" (115). Si bien es cierto que la dimensión general de lo racial es pertinente, es también cierto que la marginalidad a la que se ha sometido tradicionalmente a los 
negros no ha permitido que salgan a la luz las particularidades del mundo negro y, por consiguiente, lo simbólico rara vez ha adquirido una dimensión plena y humanamente universal. Lo preocupante del uso generalizado de lo simbólico en lo que respecta a los negros tiene que ver con el potencial de anular y de negar la legitimidad de ciertas causas y reclamos particulares. Es decir, en nombre de una supuesta condición universal ("El problema racial no es sólo el de la raza negra."), se corre el peligro de desviar la atención para, así, no tratar frontalmente las condiciones específicas de determinados grupos que viven aislados de los centros ideológicos del poder.

Brevemente, Dientes blancos tiene lugar en un cabaret centroamericano donde un conjunto de tres músicos negros se presenta ante un público blanco. William, el de la sonrisa y las carcajadas, el que se proclama “ ¡El alma negra del cabaret!” (41), ocupa el centro del escenario; a un lado, se encuentra a Peter, "sombrío" (40), quien acusa al compañero alegre: "¡Eres un traidor a ti y a la raza!" (41). La "rabia creciente" (39) de Peter se explica en parte porque es su noche de bodas y tiene que trabajar. A primera vista, la tensión entre los dos músicos parece ser el resultado de sus reacciones distintas ante la humillante necesidad de entretener a los blancos borrachos. Mientras que Peter expresa su desprecio y rebeldía, William da la impresión de ser un conformista vacío.

El desenlace de la obra ocurre cuando Peter pierde el control al ver en el esce- nario a una pareja de blancos ebrios bailando con William:

(William se acerca a los Ebrios y empieza a hacerles muecas. A bailarles. A hacerles gracias, como si se tratara de un payaso negro. Los Ebrios, al principio, no se dan cuenta de qué se trata. Después, ríen. A su vez, William empieza a reír, enseñando sus dientes blancos. Su carcajada va siendo tan contagiosa, que, al final, todos, excepto Peter, estallan en carcajadas estruendosas. [...]). (42)

Peter no soporta ni el comportamiento servicial del compañero, a quien ha llamado "¡Descastado!" (46), ni la intrusión de la pareja y, enfurecido, se arremete contra los dos blancos; a pesar de las protestas de William, el dueño del cabaret despide al músico alzado y le obliga a aquél a seguir trabajando según el gusto del público.

Para Luzuriaga,

[...] es un desenlace anticlimático, porque la simpatía que sentimos por William ha creado en nosotros la expectación, de tipo romántico, de que va a convertirse en un héroe al superponerse a la presión, pero nuestro "héroe" fracasa en su intento y termina devorado por el hábito de la obediencia diaria, $[\ldots]$ Creemos $[\ldots]$ que por el cariz irónico del desenlace, el énfasis verdadero está puesto, no tanto en la inutilidad de la rebeldía, cuanto en la opresión exorbitante ejercida por esas fuerzas prepotentes; por tanto, más que una tonalidad fatalista $[\ldots]$, predomina el iterativo tono de denuncia que caracteriza a la producción dramática de Aguilera Malta. (115-116) 
Aunque Luzuriaga acierta al destacar la falta de control y libertad que marca la vida de estos músicos, hace falta mirar más allá de la protesta social y examinar la relación entre William y Peter (i.e., la tragedia humana) como uno de los ejes fundamentales de la pieza. Conviene recordar que a pesar de las limitaciones, William no fracasa totalmente ni es completamente "devorado por... la obediencia." Cuando los ebrios subieron a la tarima, él proclamó: “Hay que aprovecharlos!” (42). William sabe sobrevivir y, en cierta manera, él sabe manipular las circunstancias en que se halla. La sonrisa, las carcajadas y los dientes blancos son un escudo detrás del cual el mundo blanco no penetra nunca $y$, por lo tanto, William adquiere cierto poder; es decir, él también ejerce algún control sobre las relaciones que tiene con los demás:

Yo siempre tomo champaña. Me gusta. $¿$ No me has visto recoger las sobras de todas las copas, cuando se van los clientes? ¡Champaña! (45)

Este tipo de poder, aunque parcial e imperfecto, no fue comprendido ni valorado por Peter quien se dejó dominar por las indignidades que lo rodeaban. De hecho, su reacción explosiva contra William y la pareja de ebrios tuvo más que ver con la incertidumbre que él sentía por haberse casado con una mujer "casi blanca." Hay que recordar que la tensión inicial de la obra surgió cuando William se reía de la situación del compañero: "Tú sabes. Yo sólo sé reír... (Transición. Eufórico). ¡Una mujer casi blanca!... ¡Jajajá!... ¡Lo que vas a tener que trabajar para que dure a tu lado!" (39).

Es al final de la obra cuando se comprende que la burla inicial de William contenía, paradójicamente, una expresión de compasión y solidaridad. El otro músico del grupo, Ernest, ya le había advertido a Peter: “¿Por qué estás así con William? El es tu amigo" (41). Lamentablemente, Peter nunca entendió al compañero cuya risa eterna servía de arma de resistencia en una sociedad con pocas alternativas viables. Con las carcajadas estruendosas, William no solamente evitaba caerse víctima de la desesperación y el rencor, sino que supo acomodarse en un cabaret que él había convertido parcialmente en un espacio propio: “¡Aquí he nacido! Aquí he vivido siempre. ¿Te imaginas esto sin la risa del negro William? Sabría mal el champaña. Las mujeres no darían el mismo placer a los hombres. El cabaret me necesita" (4041).

Tampoco comprendía Peter que el contraste de actitudes y comportamientos de los dos (i.e., la aceptación de una forma de servidumbre de William frente a la rebeldía de Peter) era más aparente que real. La situación concreta de los dos personajes se asemejaba dolorosamente puesto que las sobras del champaña que William tomaba en el cabaret no eran muy diferentes que casarse con una mujer "casi blanca." En efecto, ambos compartían una existencia, dentro y fuera del cabaret, de sobras, deshechos y marginalidad. 
Por eso, la despedida de Peter fue tan sentida por William. Al dejar de reírse momentáneamente, William se hizo vulnerable, encontrándose sin el escudo de los dientes blancos para que el público atento (y él mismo) descubriera el torbellino de conflictos y emociones contradictorias que conforman la vida de los negros todavía inmersos en mundos racistas. $\mathrm{Pa}$ ra William, la despedida de Peter representó mucho más que un desenlace arraigado en aquella protesta social vociferada por el compañero: "Aun puedo darme cuenta de la vida que llevamos. ¡Nos consumimos como antorchas negras, para alumbrar la alegría de los blancos!" (46). A fin de cuentas, Peter perdió el control, se dejó consumir por las iras y, por último, al cambiar un cabaret "de sobras" por otro (i.e., un hogar con una mujer "casi blanca”), William se angustiaba por saber al amigo indefenso y solo y, también, por comprender la futilidad de renunciar a la risa como una forma de autodefensa y, por extensión, de supervivencia:

William- ¡No quiero champaña! ¡No quiero reír! [...] Patrón-Si no ríes, ¿para qué sirves? ¿Quieres que también te despida a ti y a Ernest? (49)

Una sensibilidad agudizada por algunas de las propuestas afrocéntricas ya tratadas ayuda a poner de relieve la dimensión profundamente humana de Dientes blancos. Sin diluir la importancia de la protesta social tan hábilmente analizada por Luzuriaga, por ejemplo, he querido rescatar la centralidad de cualidades que a menudo los lectores no perciben desde su lado de los "dientes blancos" (o de cualquier otra máscara empleada por la gente negra). La compasión, la solidaridad, la angustia, el sufrimiento, la vulnerabilidad y el valor de seguir luchando según lo que las circunstancias del momento permitan constituyen el verdadero legado de William, el legado que garantiza que su función simbólica del texto dramático no encubra su condición imperfecta y humanamente universal. ${ }^{18}$

Al escribir Infierno negro en 1967, Aguilera Malta se acercó aun más al mundo negro de la diáspora. Se recordará que la obra ocurría en dos lugares: en la ciudad de Nylónpolis y en el más allá de $\mathrm{Ne}$ crópolis. El protagonista era el inventor, Hórridus Nabus, un inescrupuloso que ofrecía sus invenciones al mejor postor. Su ambición lo llevó a traicionar a los negros; con el afán de ganar dinero y prestigio social, Hórridus inventó un sistema oficial de antropofagia en el cual se trituraba a los negros para fabricar embutidos destinados a los clientes blancos. Al morir, un grupo de negros tuvo la oportunidad de enjuiciar al inventor desde Necrópolis, donde "no hay diferencia de raza, ni de fortuna, ni de jerarquía, ni de nada. ¡Todos somos iguales! Lo único que sirve para evaluarnos es el comportamiento que tuvimos en la vida terrena" (46). En cuanto a su condena, se declaró: “¿Que sufra una y mil veces, como todos nosotros cuando nos desenraizaron para esclavizarnos y lanzarnos al perpetuo exilio!” (133); “ ¡Y que en las selvas urbanas de acero y ce- 
mento sea despreciado, perseguido, marginado, escarnecido y condenado al hambre de pan, de saber y de justicia... ipor sus propios hermanos blancos!" (134).

Sin duda alguna, uno de los aspectos mejor logrados de Infierno negro ha sido la intercalación de fragmentos poéticos de diecisiete escritores, la mayoría de ellos negros, para reproducir fielmente perspectivas afrocéntricas frente al tema de la discriminación racial. Según su propia explicación, Aguilera Malta pretendió "presentar [...] con esa mínima antología poética [...] la biografía poética de los negros con su raza africana, con su ritmo, con su sentido peculiar de la vida, con una especie de medianismo reivindicado que está animando hoy la negritud" (en Rabassa 130). Luzuriaga, también, ha observado:

Por su contenido y emoción, la secuencia poemática representa una evocación trascendente de la raza africana, y el dramaturgo, para lograr una evocación auténtica, ha acudido, con buen criterio, a quienes, por pertenecer a esa raza-como Langston Hughes, Nicolás Guillén o Birago Diop-están más capacitados que él, de ascendencia europea, para tal cometido. (138-139)

La relación dialogal entre negros y no-negros a la que me referí al principio del capítulo parece haber florecido en $I n$ fierno negro. Sin proponer hablar por los negros, Aguilera Malta se puso a un lado para que ellos mismos se establecieran como las autoridades de sus experiencias como negros. Indudablemente, esta apertura de comunicación se debía al estudio in- tenso al que Aguilera Malta se había sometido antes de escribir la obra. ${ }^{19}$ A diferencia de Canal Zone y Dientes blancos, dos textos en que él había sido impulsado por experiencias fugaces e impresionistas propias de viajes momentáneos a lugares con importantes poblaciones negras, Infierno negro fue el producto de una especie de afrocentrización en que los conocimientos adquiridos directamente de fuentes afro parecen haber convencido a Aguilera Malta de sus propias limitaciones como intérprete del mundo afro. Por lo tanto, la estructura paralela de Infierno negro sugiere un modelo de acción para futuras alianzas; es decir, la denuncia con su correspondiente interpretación de los hechos no ha de ser una apropiación cultural que termina negándole a la gente afectada (a los negros, por ejemplo) el rol protagónico en la defensa, articulación y resolución de su causa particular.

\section{B. José de la Cuadra}

A diferencia de Dientes blancos y de Infierno negro donde el referente ecuatoriano está completamente ausente (ni siquiera se encuentra una voz poética afroecuatoriana en la antología de la segunda pieza dramática), en Los monos enloquecidos de José de la Cuadra, la presencia vital de la Costa ecuatoriana es inconfundible. Por lo tanto, mientras que lo pertinente al tema negro en el contexto nacional puede perderse en el enfoque abstracto de Aguilera Malta, para Cuadra lo racial constituía un "problema" definitivamente nacional. Humberto Robles, uno de los ma- 
yores críticos de la obra de Cuadra, ha puntualizado:

[...] una recuperación literaria del topos sobre el prestigio racial y sus consecuentes ramificaciones respecto a sujeto, hábitos, usos, valores y ejercicios de poder, tiene que tener en cuenta en el Ecuador obras como, por ejemplo, Los monos enloquecidos $(1931,1951)$ [...]. Esta novela inconclusa se adelantó al exponer e interpretar, con no poco de ironía, las manías de los grupos hegemónicos guayaquileños que niegan y desdeñan su cualidad mestiza (mulata), apuntando así a una fundamental escisión y crisis de identidad. ("Reseña sobre El Chulla Romero y Flores" 721)

Por eso me referí en páginas anteriores a la tendencia de negar las raíces negras como tema palpitante en la obra de Cuadra, corroborando lo que Toni Morrison había observado desde otro rincón de la diáspora: "Lo que se hizo evidente fueron las maneras patentes que los [norte] americanos escogen para hablar de sí mismos mediante y dentro de una representación de una presencia africanista que si bien es a veces alegórica y, otras veces, metafórica, es siempre sofocada" (Playing in the Dark... 17; traducción mía). La coincidencia entre el caso norteamericano y el ecuatoriano se patentiza al leer en Los monos enloquecidos que se había creado la fábula sobre el matrimonio del primer Hernández de la familia del protagonista, un español, con "la hija de un reyezuelo africano" (9), precisamente para disimular ciertos rastros cuestionables de alcurnia:
Algunos malintencionados circulaban la especie de que todo aquello era pura fábula, y que los próceres criollos la habían inventado para justificar los feos saltos atrás que se notaba en algunos de ellos a lo largo de las generaciones. Nada se logró probar sobre estos puntos, y eran admitidos con ciertas reservas. (9)

Y, de nuevo, los comentarios de Robles son instructivos:

Resulta claro que de la Cuadra no sólo se propone desmitificar y parodiar las ínfulas y fantasías de las clases dominantes guayaquileñas, sino incluso ir más alláinsistir en que los componentes raciales que determinan el mestizaje costeño del Ecuador, sin excluir el de los "criollos" terratenientes, consignaban una mezcla histórica de amerindio, negro y blanco. ("Los monos enloquecidos en el país de las maravillas...”7)

Básicamente, Los monos enloquecidos trata de la vida de Gustavo Hernández, quien después de veintinueve años de viajar por todo el mundo, regresó al Ecuador a establecerse en Pampaló, la hacienda familiar de la Costa, donde supuestamente existía un tesoro de oro escondido. Su gran ambición era encontrar dicho tesoro $y$, para este fin, pensaba emplear a una veintena de monos para la excavación. Según Masa Blanca, el brujo y socio de Gustavo, él mismo había visto el tesoro, pero, desgraciadamente, "el diablo se había apoderado del entierro y que lo hundía cuando cavaban para buscarlo" (149-150). Para rescatar el tesoro, Masa Blanca indicó la fórmula: 
Mandar a decir por el ánima del difunto dueño del tesoro, las treinta misas de San Gregorio y las tres de la Santísima Trinidad... Que paseara en cruz sobre el terreno una doncella probada... Que se escarbara el suelo cuando la luna estuviera en su cuarto creciente... Que las manos que laboraran en la excavación, no se hubieran mojado jamás en agua bendita... Que el trabajo fuera empezado en domingo... En fin... (150)

Poco después de escuchar al brujo, se le ocurrió a Gustavo que los monos eran los que podían hacer la excavación puesto que "sólo ellos y los indios salvajes-que son en menor número de lo que debieran ser-, no han sumergido sus dedos en el líquido sucio y salobre de las pilas consagradas de este convento grande que es, todavía, la que estuvo a punto de convertirse [...] en la República del Corazón de Jesús” (153).

Es precisamente en ese mundo exagerado de fantasías, ilusiones y magia donde Cuadra asentó su visión paródica para llevar a cabo "un proyecto cultural cuya meta, en el fondo, no era otra que la de señalar anomalías en vigencia. El objetivo sería promover una revisión histórica de la conciencia nacional con miras a efectuar cambios en las estructuras de poder que regían la esfera pública, el ámbito social, y el sentido de identidad ecuatoriana" (Robles, "Los monos enloquecidos en el país de las maravillas...," 5). Me parece que una de las claves fundamentales de la novela para comprender cabalmente la preocupación de Cuadra por "las anomalías," "la revisión histórica" y "la conciencia nacional" es la narración misma acerca de los monos que, según mi lectura, sugiere una denuncia de la esclavitud y de muchas de sus consecuencias en la historia del Ecuador.

Además de las obvias asociaciones que, desde hace mucho tiempo, se acostumbra hacer entre los monos y la gente negra-asociaciones que, con demasiada frecuencia, han sido profundamente marcadas por motivos racistas-, la correspondencia entre los monos y los costeños ecuatorianos, concretamente, es archiconocida en el folklore nacional; también, se sabe que, a nivel internacional, los peruanos todavía acostumbran emplear el apodo al referirse a sus vecinos del norte. ${ }^{20}$ En este sentido, entonces, no parece que Cuadra haya hecho nada nuevo al llevar a su novela una imagen tan conocida para el disfrute general de sus lectores. Pero, las apariencias engañan, especialmente cuando se trata de un escritor como Cuadra, maestro de la ironía y del doble sentido. En efecto, las referencias constantes al potencial humano de los monos, junto con la ya mencionada crítica de un racismo latente tan manifiesto en la negación de raíces negras, parecen anunciar otra pista de interpretación que hasta ahora no se ha comentado mayormente al analizar Los monos enloquecidos.

No estará de más traer a colación aquí la referencia satírica que Gustavo lanzó contra los etnólogos alemanes y, por extensión, contra muchos de los teóricos evolucionistas del siglo XIX: "Esos ridículos doctores de cabezas cuadradas, que 
han viajado por Oceanía [...], no vieron las realidades lealmente, fielmente..., sino a su acomodo, tratando de comprobar las lerdas y cachazudas teorías que inventan. ¿No comprenden? ¡Si lo propio han hecho en las Galápagos!” (41). En contraposición de esta ciencia inventada de los europeos, se lee en la novela que

Hernández poseía [... ] una fantasía desbocada; $y$, es de suponer que su estada en las islas de los galápagos, unida a sus lecturas posteriores de Darwin, Agassiz y otros, juntamente con sus viajes por el sertao del Mozambique portugués, fue lo que hizo brotar en su cerebro aquellas sus raras ideas sobre los monos y su evolución, que más tarde pretendió poner en práctica. (34)

Al romper la autoridad sin límites de los científicos europeos, Gustavo pudo introducirse en otras esferas del saber: "Dijo Gustavo Hernández que los negros brujos de Africa conocían métodos maravillosos para adelantar la evolución de los monos y que él—de quererlo-podía emplear tales métodos, cuya clave dominaba" (134). De modo que de su "fantasía desbocada" frente a teorías sagradas, que desde hace muchas décadas habían sido descalificadas por ser igualmente desbocadas, surgió una yuxtaposición de fantasías, algunas más oficiales que otras, a partir de la cual Cuadra había preparado el terreno narrativo para invertir y entrelazar conceptos, convirtiendo realidad en ficción y ficción en realidad. La confluencia de interpretaciones diametralmente opuestas sigue manteniendo abierta la posibilidad de nuevas lecturas creativas que no se han de acabar nunca. ${ }^{21}$

En la novela, hay dos episodios en particular donde se vislumbran los paralelos entre el cuento de Gustavo, quien pensaba usar a los monos en su búsqueda del tesoro perdido, y la historia de los negreros quienes habían encontrado en la esclavitud un mecanismo de enriquecimiento y de poder. Primeramente, se lee:

Contra los monos nunca había disparado.

- Se me ocurriría estar cometiendo un homicidio. ¡Son tan semejantes a nosotros!

Los llamaba "nuestros primos" y jugaba chanzas sobre el atribuido parentesco.

- He leído en un trabajo del profesor Campos que, en nuestro país, hay cuarenta especies de simios. Es un récord.

Después decía que había razón para que a los ecuatorianos nos apodaran de monos, y que, si fuéramos aún tribu salvaje, indiscutiblemente nuestro totem sería el mono. (114)

Con lo citado, Cuadra estableció claramente, por un lado, la humanidad de aquellos personajes llamados monos, pero lo hizo desde una perspectiva de superioridad. Gustavo los consideraba primos en vez de hermanos; semejantes, sin ser iguales. Este distanciamiento (o jerarquización) era la misma estratagema que manejaba el esclavista (o cualquier colonialista); mientras que éste aceptaba al negro como parte de una gran familia cristiana, no olvidó nunca quién era el amo. Por 
otro lado, se desprende de lo narrado que aquellos monos ocupaban un lugar central en el Ecuador, tanto por su variedad y número como por ciertos rasgos culturales comunes que no se nombraban abiertamente, pero que sí habían de existir en vista de la aceptación del mono como totem propio, como un icono mítico nacional.

El segundo episodio pertinente a la parodización que Cuadra había empleado como recurso novelesco para denunciar (¿deconstruir?) la esclavitud se encuentra al final de la novela. Según ofrece el texto:

Hernández contemplaba a los simios. Los admiraba. Fijaba la atención, prolongadamente, en sus gestos vivos, en sus faces inteligentes donde los ojillos se movían incansables, brillantes, expresivos.

¡Los monos!

$[\ldots]$

Sí; innegablemente remedaban hombres no acabados de hacer, humanidades en potencia.

En especial, aquél. Aquél, mayor que todos, que se colgaba del rabo prensil, enredándolo en una de las vigas cañizas del techo....

Era un hombre. Le faltaba hablar como los hombres, reír como los hombres, llorar como los hombres. Nada más. Pero, a pesar de eso, era un hombre.

—Un hombre....

$[\ldots]$
Siguió pensando. Pensando. El—Gustavo Hernández-haría. ¡Haría! Su nombre volveríase famoso, imperecedero. Los siglos se amontonarían encima de los siglos; $y$, sin embargo, su nombre quedaría.

Colón dio un mundo más, al mundo. Su obra sería superior a la del pobre almirante. Porque él daría una humanidad nueva a la humanidad.

[...]

Pero era menester, primeramente, mirar por lo inmediato.

Los monos estaban ahí, y estarían ahí por siempre, arcilla propicia para cualquier obra. Los tendría cuando quisiera. Ahí. A su disposición. A su mandar, cautivos. Ahí.

Lo inmediato era el tesoro. Extraerlo. Desentrañarlo. Sacar a superficie lo que la tierra se había tragado.

Por lo pronto habría que emplear a estos seres humanos en potencia en la modesta labor de cavadores.

Lo otro... ¡lo otro!... sería más tarde.... (165-166)

De nuevo, la humanidad de los monos se pone de relieve junto con la dominación de Gustavo y su razonamiento esclavista/colonialista que prometía una labor evangelizadora (i.e., completar la humanización de los monos) para, así, justificar el trabajo forzado que era supuestamente temporal. De ahí que son innegables las correspondencias con la esclavitud: se considera a los monos (sub)hom- 
bres; se los reconoce como "cautivos" a la disposición de Gustavo, el amo. En fin, la esclavitud como una institución oficial tuvo su base en lo económico, en aquella fuente de poder y de privilegios. Dentro de la parodia de Cuadra, Gustavo recordaba toda una tradición e historia de "anomalías” y, más concretamente, según Robles:

[...] sólo viendo las experiencias del protagonista en su totalidad es posible fijar la organización interna de esta obra. Sólo así se podrá señalar que quizá toda la vida de Hernández no es más que un velado afán por restaurar, por actualizar en sí mismo, el esplendor que cuenta la tradición de su estirpe. (Testimonio y tendencia mítica en la obra de José de la Cuadra 157)

La inversión de signos y significados dentro de un ambiente mítico donde los límites entre la locura y la cordura eran borrosos, cuando mucho, remite al lector a un mundo en el cual proyectos fundacionales de una supuesta nación se han caracterizado tanto por sus afirmaciones como por sus negaciones, y éstas (las afirmaciones y las negaciones), claro está, también se han caracterizado por sus límites igualmente borrosos. Por eso se ha constatado que toda nación es producto de la imaginación (Anderson, Imagined Communities) y, en este sentido, en Los monos enloquecidos Cuadra parodizó a una nación cimentada en "la propensión a negar la realidad cotidiana, a querer ser más que los otros $\mathrm{y}$, mucho más pertinente en la novela, a suplantar la verdad con la fantasía" (Robles, Testimonio y tendencia mítica en la obra de José de la Cuadra, 155). Según mi lectura, no se puede aprehender plenamente este trastrocamiento nacional sin tomar en cuenta la presencia, muchas veces invisible, de los afroecuatorianos. En efecto, mediante la parodia de Gustavo y los monos enloquecidos, Cuadra ha recreado la oblicuidad con que la presencia afro ha sido tratada (i.e., negada/encubierta/blanqueada) en el Ecuador. Al mismo tiempo, Cuadra ha dejado a sus lectores con una inquietud por resolverse: ¿no será el tesoro perdido de Pampaló la verdadera historia nacional, la historia plurinacional en la cual ha de brillar, con toda su potencia, aquella presencia afroecuatoriana que tantas veces ha sido apoderada y enterrada por algún "diablo" de turno?

\section{Enrique Gil Gilbert}

Enrique Gil Gilbert escribió "El negro Santander" en 1932, publicándolo en 1933 como parte de su colección de relatos intitulada, Yunga. A primera vista, "El negro Santander" era principalmente un cuento del realismo social; el "yo-acuso" parece prevalecer en ese texto sobre el trabajo forzado que sufrieron, entre otros, los indios, los negros y los cholos a fines del siglo XIX y a comienzos del XX cuando se construía el ferrocarril que, eventualmente, vincularía a Guayaquil (la Costa) con Quito (la Sierra). La denuncia contra el imperialismo norteamericano no se le escapó a Gil Gilbert, tampoco. A pesar de las advertencias de Santander ("Yanquis, yanquis. Mala gente," 16), a muchos no les fue fácil vencer la tentación de los dólares: 
—Los dólares son de oro y valen más que el sucre.

—Nos pagarán en dólares.

—En dólares. (17)

Desgraciadamente, "Los gringos se creían superiores a todos" (20) y, como era de esperar, la promesa de los dólares se convirtió en una pesadilla de explotación, racismo y destrucción.

La singularidad del cuento, sin embargo, surge de la caracterización del protagonista, el negro Santander. Como ha sido el caso con otros textos del Grupo de Guayaquil, este cuento se adelantó a su época, especialmente en cuanto a la concepción que Gil Gilbert formuló sobre lo nacional desde la marginalidad. Hay que recordar que la construcción del ferrocarril implicó la unificación del país y, por consiguiente, no sería una exageración relacionar ese proyecto de infraestructura nacional con la construcción de un Ecuador moderno. Curiosamente, lo más destacable de la interpretación que Gil Gilbert hizo acerca de ese momento histórico fue la función central realizada por un personaje negro, el mayor intérprete de los orígenes de la nación moderna. Fue a través de sus recuerdos y de su testimonio que los lectores pudieran trascender aquellos mitos oficiales que habían glorificado lo que todavía reclama la justicia y la verdad. Según se lee:

—Pero, don Santander, si el ferrocarril es lo mejor...

El los cortó groseramente.
- ¿Ustedes qué saben?; ustedes no han trabajado allí. El negro se hizo viejo en la línea.

-Alfaro, y dicen que García Moreno también, fueron los que hicieron la línea. Por eso ya el uno tiene estatua.

—Ellos no hicieron nada, no trabajaron. No; ellos no comprenderían lo que les dijo Santander. Y a más, Santander era loco, y:

—Los locos no son hijos de Dios. (52)

De modo que, todo el cuento gira en torno al testimonio del negro y la medida en que él constituía una autoridad de los acontecimientos tratados:

Y todos saben de memoria, y lo repiten, lo que les ha contado el negro Santander cuando no está loco. (13)

Diz que [los gringos] venían de lejos, de donde hay que pasar el mar. Santander los conocía [...]. (16)

Santander supo que a los indios no les pagaban. (19)

Los costeños eran tísicos. Los vio, sí, los vio él. (19)

Santander sabía por qué era idiota el indio Chiluisa.

Y narró [...]. (31)

Lógicamente, su condición de otredad (i.e., era negro y extranjero) complicaba la recepción de sus memorias, hundiéndolas en un ambiente de confusión, escepticismo y miedo: 
—Mamita, el negro diablo, ¿̇lo oyes?

[...]

- Habla una lengua que no entendemos, cuando está loco.

—La lengua del diablo. (12)

[...]

El negro blasfema a la noche impasible. La noche, negra abajo, azul arriba, baila la inquietud de las estrellas.

—El negro Santander es loco.

—Los locos no son hijos de Dios.

— ¿Si no de quién?

-Del diablo.

- Mamita, dame agua bendita para santiguarme. (13)

En realidad, Santander no estaba loco ni era el diablo. El gran acierto de Gil Gilbert fue el haber captado en el cuento la conflictividad y la complejidad inherentes a sociedades cultural y socialmente pluralistas como el Ecuador. Frente al mito nacional de un mestizaje unificador, Gil Gilbert recordó a sus lectores la diversidad ecuatoriana mediante un personaje que manejaba un nuevo lenguaje, un lenguaje híbrido y plurinacional que exigía la deconstrucción de una historia nacional anacrónica y la reconstrucción de un Ecuador fiel a su multiplicidad.

Vale recordar de nuevo que Santander era uno de los jamaiquinos que había llegado al Ecuador precisamente para tra- bajar en el ferrocarril y, por lo tanto, su otredad radicaba en el doble hecho de ser negro y de habla inglesa en un país que tradicionalmente se definía como blancomestizo, católico y de habla española. ${ }^{22}$ En términos simbólicos, al convertir al negro Santander en el vocero del Ecuador moderno, Gil Gilbert insertó la historia nacional dentro de la diáspora, la liminalidad y, sobre todo, dentro de la plurinacionalidad. En efecto, para Gil Gilbert, el Ecuador como nación era "un espacio fluido y ambivalente entre mundos profundamente diferentes" (Goldberg). ${ }^{23}$ De ahí, la explicación de que

Santander no estaba del todo loco y, reunidos en el galpón grande, les narró-como siempre-mal. Dejaba ver en sus ojos, en su cara, que revivía aquella vida. Hablaba desde muy lejos de ese momento, lentamente, con su mezcla de inglés y de castellano, royendo las palabras. Miraba más allá, donde no entraba su idioma para salir hasta los peones.

Mas, él veía todo intacto, como entonces.(37)

El lenguaje mezclado de Santander pertenecía a dos mundos y a dos épocas que eran diferentes y, a la vez, estaban profundamente interconectados. Por eso, la confluencia de su pasado como afro, como jamaiquino y como integrante de la (de)(re)construcción del Ecuador moderno:

Silenció el negro. Con los ojos medio cerrados, vio su vida dejada. Lejos, allá, en un arrozal lleno de agua, blanca la extensión, dorada del sol por encima, gruesa de 
blancura como carne de coco. Lleno estaba todo del grito pampero del tambor y del trinar dolido de la marimba negra y del roncar de patada de los bongós. [...] ¡si todo eso volviera!

— ¡Ya no sería loco el negro Santander!

A él mismo lo extrañó su voz. Comprendió en la sonrisa de los peones el creer de ellos en su locura.

—No es locura, no; me acordaba...

—Pero no acabó de contar de la Nariz del Diablo.

—Cierto, cuéntenos...

Y él habló. (44-45)

Angustia más que locura; la angustia del recuerdo de los orígenes del Ecuador moderno era lo que caracterizaba al negro Santander. También, él se angustiaba por saber que sus orígenes como afroecuatoriano habían surgido junto con la Nariz del Diablo, con aquella formación de piedra en los Andes, emblema de la tragedia humana que nació al estallar la dinamita que se usaba para abrir el paso en la construcción del ferrocarril y, por extensión, del Ecuador moderno.

Tuvo un sonar horrible, como si la roca entera se trizase en mil pedazos.

Santander estaba bien hasta contar esto. Aquí le saltaron los ojos, los fijó en el infinito, y entre inglés y castellano, dijo:

—Los vi, muchos, sí, muchos volaron junto con las piedras... Y yo vi a Johnson quedar muerto y amarrado con la cabeza rota... Y antes también vi negros, ipobres negros!, amarrados y muertos de tres días... (46)

Gil Gilbert comprendió que la amplia y heterogénea historia del Ecuador no sería completa hasta que se escucharan todas las voces, incluyendo entre ellas, las de los afroecuatorianos. Las experiencias colectivas del sufrimiento y del sacrificio de los negros en el Ecuador han de considerarse la otra cara de las supuestas glorias nacionales. Pero, como ha sido el caso del negro Santander-aquel negro extranjero que, debido a su incorporación paulatina en la historia nacional, representaba a un afroecuatoriano en formación-, los negros ecuatorianos compartían la misma experiencia de estar sujetos a diversos procesos de marginalización y anulación: "Los demás que lo oían, no comprendían, en verdad, lo que opinaba el negro" (52). Seguramente, el racismo latente de la sociedad, de alguna manera, había detenido los esfuerzos por comprenderlo; por eso, tanta insistencia en su supuesta "locura." La representatividad actual de lo enigmático de Santander como un mecanismo potencial de deslegitimación se refleja en un reporte publicado por la Organización de Estados Americanos en 1997. Según la Comisión de los Derechos Humanos:

Se le informó a la Comisión que la historia de la población afroecuatoriana no se conocía mayormente y, tampoco, se la incluía en el pensum académico nacional en cuanto a la historia nacional del país. Esto fue caracterizado por los afroecuatorianos como una manifestación de la infe- 
rioridad con que se los trata como un sector social-y como un mecanismo para seguir reprimiendo su identidad, historia y cultura. (118; traducción mía)

Al leer hoy día "El negro Santander," uno se da cuenta de la importancia de incluir al negro en la recuperación de la nación. Su autoridad se fundamentaba, precisamente, en su otredad que servía de complemento esencial de aquellas historias oficiales en las que se había creado a un Ecuador según los intereses tradicionales de algunos conocidos grupos hegemónicos del país. A pesar de las tentativas de silenciar la voz del negro Santander mediante las ya mencionadas acusaciones de su locura, por ejemplo, Gil Gilbert logró contrarrestarlas con la ironía y con un trastrocamiento de valores y significados tradicionales: la construcción venía a ser la destrucción, la locura venía a ser la cordura y la otredad venía a ser uno de los pilares fundamentales del Ecuador plurinacional. Por eso, es significativo que el negro Santander haya recogido a todos los marginados en su recuperación de los orígenes del Ecuador moderno: "indios, costeños, serranos, gringos, negros” (39). En efecto, Gil Gilbert volvió a la historia para (re)escribirla desde los márgenes de la sociedad oficial, constatando que una parte vital de la historia ecuatoriana seguía (sigue) enterrada en la memoria colectiva de los afroecuatorianos, de aquella gente cuyos orígenes transnacionales han de considerarse fundamentales para la sustancia misma de la plurinacionalidad ecuatoriana. De una manera u otra, Gil Gilbert pa- rece haber intuido esa realidad al colocar al negro Santander en el centro mismo del Ecuador moderno.

\section{Conclusión}

Uno de los cometidos de los escritores de los años 30 en el Ecuador fue el de crear una literatura nacional, dejando atrás una larga tradición oligárquica y aristocratizante. Dentro del papel ejemplar que el Grupo de Guayaquil jugó en ese proyecto de reivindicación de las mayorías del país, se destaca su interés por captar la presencia de los negros en el escenario nacional. De las obras analizadas, se vislumbra la complejidad del tema negro en la literatura ecuatoriana, tanto como un objeto de la escritura como de la lectura.

Sin duda alguna, en las obras de los integrantes del Grupo de Guayaquil, ha habido mucha variedad en cuanto a la caracterización de los personajes negros que ha oscilado entre lo caricaturesco y los comienzos de una perspectiva que apuntaba hacia lo afroecuatoriano. Puesto que el principal contacto que muchos lectores han tenido con los negros ha sido a través de la literatura, se comprende la medida en que la ficción (y otras formas de escritura) ha condicionado muchas actitudes respecto a la gente negra del país. Al mismo tiempo, hay que recordar que, a menudo, se han empleado las lecturas para legitimar conceptos perjudiciales y hasta racistas. Por eso, sigue siendo vital someter las obras y su recepción a lecturas comprehensivas, a lecturas que valoren los tex- 
tos simultáneamente como expresiones estéticas e interpretaciones socioculturales.

Aunque será imposible aprehender cabalmente la complejidad del mundo de los negros sin la participación activa de los negros mismos, las contribuciones literarias del Grupo de Guayaquil han constituido un gran avance en la lucha por sacar a los negros de la invisibilidad. En el fondo, al estudiar los textos comentados arriba, lo que más llama la atención es una creciente concientización de la centralidad que los negros del Ecuador han ocupado (y ocuparán) en la construcción de un país plurinacional. Desde lo simbólico empleado como instrumento de protesta y denuncia hasta su conversión en vocero de un nuevo Ecuador, el negro ecuatoriano sigue evolucionando en la imaginación de los blanco-mestizos. Se espera que mediante nuevas lecturas, lecturas informadas por perspectivas afrocéntricas, se logre desenterrar el tesoro escondido de conocimientos y experiencias que son la sustancia misma de lo afroecuatoriano, de uno de los pilares inquebrantables de un Ecuador democrático, justo y plurinacional.

\section{Notas}

1 Volveré a estos comentarios más adelante: para el de Aguilera Malta, véase el capítulo IV; para el de García Salazar, el capítulo VII.

2 La misma problemática fue planteada por Mariátegui al referirse a las limitaciones de la literatura indigenista; en cuanto a la literatura escrita por mujeres, la ginocrítica ofrece conceptos útiles para una lectura afrocéntrica.
3 Para los que no tienen mayores conocimientos de la literatura ecuatoriana, convendría consultar los siguientes dos estudios generales acerca de los principales escritores de los años 30, incluyendo a los cinco de Guayaquil: el prólogo de Jorge Enrique Adoum en la edición que él y Pedro Jorge Vera prepararon y que se tituló Narradores ecuatorianos del 30 (Caracas: Biblioteca Ayacucho, 1980); Miguel Donoso Pareja, Los grandes de la década del 30 (Quito: Editorial El Conejo, 1985).

4 Para un análisis más elaborado de las tensiones entre la clase social y la raza negra como fuentes y objetos de protesta, véase el capítulo $\mathrm{V}$ en que estudio Juyungo, la novela de Adalberto Ortiz.

5 Empleo el término "no-negros" en vez de "blancos" por dos razones. En primer lugar, el mundo en que vivimos es más complejo que uno de dos razas; en segundo lugar, "no-negros" establece como norma la negritud para, así, poner de relieve la condición incompleta de los demás vis-à-vis los negros.

6 Vuelvo a tocar este tema al referirme a W.E. B. DuBois y su concepto de la doble conciencia en el capítulo sobre Juyungo.

7 Traté este problema en el capítulo anterior al comentar brevemente los efectos nocivos de la apropiación cultural en sociedades antidemocráticas. No estaría de más mencionar aquí lo polémica que ha sido la creación de categorías de identificación y de estrategias de presentación para grupos no canónicos. Gran parte de los debates al respecto han girado en torno a los peligros del separatismo y de la integración. Por ejemplo, se piensa que si se habla de una literatura negra (o de mujeres), se corre el riesgo de separarla de "la literatura"; al mismo tiempo, si no se hace ninguna distinción, se corre el riesgo de perderse en generalidades que encubren las particularidades de las diferencias. 
8 Para más información histórica y cultural acerca de la presencia negra en la Costa ecuatoriana, véanse los siguientes dos capítulos.

9 Ya indiqué que Baldomera es la protagonista de Baldomera, novela de Pareja Diezcanseco de 1938; Alfredo Baldeón es el protagonista de Las cruces sobre el agua, novela de Gallegos Lara de 1946.

10 Convendría recordar aquí a Leslie Rout, quien escribió: "Exteriormente, el problema de los negros parecería casi idéntico al de un sinnúmero de indios y mestizos de América Española. Sin embargo, aunque esa gente es pobre, analfabeta y explotada por una minoría rica que se considera blanca, hay diferencias significativas. En Paraguay, los países andinos y México, un mestizo o hasta un indio que hable bien el castellano y lleve ropa occidental puede hacerse 'blanco.' Además, en Perú y México [...] el indigenismo ha sido ratificado oficialmente, y una afirmación de tener sangre india, de una manera variada, puede estar a la moda. Fíjese, como contraste, que no hay lugar en América Española donde la negritud sea fomentada por orden del gobierno" (318; traducción mía).

11 Después del asesinato de Eloy Alfaro y el comienzo del segundo gobierno de Leonidas Plaza en 1912, el Coronel Carlos Concha inició en nombre de los principios liberales de Alfaro una lucha armada en Esmeraldas que duró tres años (1913-1916).

12 Aunque un zambo no es exactamente un mulato, he tomado aquí cierta licencia al emplear un término racial ampliamente conocido para señalar la mezcla que caracteriza a Baldeón, una mezcla sumamente difícil de precisar si se toma en cuenta los múltiples cruces raciales de la población general del Ecuador.

13 Para un análisis feminista de esta novela, véase $\mathrm{mi}$ "Baldomera y la tra(d)ición del orden patriarcal," Inti, 40-41 (otoño 1994-primavera 1995), 195-205.

14 Camilla Townsend ha ofrecido un análisis lúcido sobre la historia de las mulatas en Guaya- quil en una conferencia que ella dio en un congreso auspiciado por SECOLAS en abril de 1992. También, Jonatás y Manuela, la novela de Argentina Chiriboga que analizo en el capítulo VI ofrece una visión profunda de la mujer negra del Ecuador de fines del siglo XVIII y comienzos del XIX.

15 Toni Morrison, Premio Nobel de Literatura de Estados Unidos, ha recordado que tanto en el teatro de variedades como en la literatura se ha empleado a menudo a figuras negras para representar temas que, de otra manera, se hubieran considerado tabúes (véase Playing in the Dark...).

16 Para más comentarios sobre Siete lunas y siete serpientes, véanse Luis A. Díez, "The Apocalyptic Tropics of Aguilera Malta," Latin American Literary Review, 10, 20 (Spring-Summer 1982), 31-40; Antonio Fama, Realismo mágico en la narrativa de Aguilera-Malta (Madrid: Playor, S.A., 1977).

17 La primera obra de Aguilera Malta en que apareció su interés por la discriminación fue su novela, Canal Zone (1935). Aunque esta novela fue escrita en la misma época de Los monos enloquecidos y "El negro Santander," no será comentada en este estudio por dos razones: en primer lugar, trata el problema del racismo en el contexto preciso de Panamá y, por lo tanto, su dimensión "internacional" se reduce a otro espacio "nacional" que hace difícil establecer vínculos con la situación ecuatoriana; por otro lado, el nivel de abstracción de los dos dramas permite una lectura más afín con mis propósitos comparativos.

18 Clementine Rabassa ha ofrecido una interpretación muy sugerente de William en "Hacia la 'negritude': las ediciones variorum de Dientes blancos," en su En torno a Aguilera Malta, 132152.

19 En una entrevista con Clementine Rabassa, Aguilera Malta comentó: "En Dientes es el impacto de una realidad inmediata. En Infierno hay una larga preparación y estudio. Por razones de trabajo, y desde luego debido a mi pa- 
sión por el tema y la injusticia social y antihumana implicada en el mismo, empecé lecturas y traducciones de algunos autores negros, como por ejemplo Frantz Fanon [...] Fue un período de lecturas voraces de cuanto pude obtener para conocer un tanto la materia" (Rabassa 126).

20 Aparte del plano despectivo y racista, hay que recordar que el mono ocupa un lugar positivo en ciertos mitos afro; véase, por ejemplo, Henry Louis Gates, Jr., The Signifying Monkey, 77.

21 Con mucha razón, Robles ha constatado que Los monos enloquecidos "es quizás la obra que más se presta a mayores posibilidades de lectura [...]" ("Los monos enloquecidos en el país de las maravillas..."1).

22 Es interesante notar que el modelo del personaje era muy querido por Gil Gilbert, quien en una carta dirigida a Benjamín Carrión en 1932, explicó que su cuento "Trata sobre la construcción del ferrocarril de Guayaquil a Quito, tal como me lo contó un negro sobreviviente que trabaja en la hacienda de mis abue- los" (Salazar, comp. Benjamin Carrión, Correspondencia I, 108).

23 Básicamente, la liminalidad se refiere a un espacio transicional donde grupos diferentes (re)negocian sus límites y fronteras-es decir, aquellas divisiones (distinciones) tradicionales que ahora se comprenden por su fluidez y confluencia constante. El afroecuatoriano, por ejemplo, es el producto de la liminalidad ya que sus múltiples condiciones (i.e., afro, ecuatoriano, hombre, mujer, clase social, identidad geográfica, etc.) se encuentran en un estado de definición perenne. Para una aplicación de este concepto de la liminalidad a la literatura ecuatoriana, véanse: Paul Goldberg, "Currents of Liminality: Religious Syncretism and the Symbolism of the River in Cumandá," ponencia presentada en el Congreso de Literatura de Kentucky (abril 1997); Michael Handelsman, "Cumandá entre el proyecto nacional decimonónico y la plurinacionalidad de fines del siglo veinte: una lectura postcolonial," ponencia presentada en el Congreso de Americanistas (julio 1997). 


\section{Capitulo III \\ Recuperando una canción dos veces perdida: Un análisis afrocéntrico de Tambores para una canción perdida, de Jorge Velasco Mackenzie}

La canción dos veces perdida a que me refiero en el título de este capítulo tiene que ver con una novela que trató de rescatar la historia del negro en el Ecuador $y$, en el proceso de leerse y de discutirse, también fue silenciada y marginada por una serie de circunstancias curiosas y controvertibles. De buenas a primeras, he de sugerir que tanto Tambores para una canción perdida (1986) como el lugar que ocupa la cultura afroecuatoriana en la historia nacional, constituyen un reto a ciertos conceptos tradicionales de una ecuatorianidad vista principalmente dentro de un contexto andino.

Insistir en un mestizaje primordialmente blanco-indio, o conceptualizar lo andino en base a criterios exclusivamente geográficos (i.e., las cordilleras), equivale a forjar esquemas nacionales en los que se diluyen las complejidades de las culturas costeñas, por ejemplo, cuya afinidad con el Caribe es ampliamente sentida. Como es de suponer, al destacar lo caribeño como componente vital de la Costa ecuatoriana, se está reconociendo la centralidad de herencias y rastros africanos que han sobrevivido consciente o inconsciente- mente durante cinco siglos de historia nacional. Conviene recordar que la mayoría de la gente "en la región caribeña, de hecho, es de origen africano. La herencia cultural africana constituye uno de los rasgos definitorios de lo caribeño [...]" (Smart, Central American Writers of West Indian Origin, 12; traducción mía). Por otra parte, lo caribeño/africano en la Costa ecuatoriana ha superado toda configuración fenotípica. A diferencia de otros estudios en los cuales se ha destacado lo afroecuatoriano como la creación de un sector negro del país arraigado, sobre todo, en Esmeraldas, y que ha tenido que enfrentarse con otras culturas nacionales capaces de blanquear y desvirtuar lo negro, yo pretendo poner a un lado las dicotomías fenotípicas y partir, más bien, de una premisa afrocéntrica que resalta un proceso cultural de africanización adaptada al contexto ecuatoriano, $y$ sobre todo, al contexto costeño del país. En efecto, "La negritud es más que un hecho biológico; realmente, es más que el color; funciona como un compromiso a un proyecto histórico que coloca de nuevo a la persona africana en el centro..." (Asante 125; traducción mía). 
Lo polémico de este enfoque cultural ya fue tratado por Herskovitz en su estudio clásico, The Myth of the Negro Past, donde él cuestionó todo intento de negar la supervivencia de lo africano en el Nuevo Mundo. Según puntualizó:

Y ¿si el cálculo de africanismos no es correcto? Y ¿si estas culturas [de Africa, de donde los negros del Nuevo Mundo han venido] les habían influido a sus transmisores, y a los descendientes de sus transmisores, con demasiada profundidad para no ser eliminadas más de lo que fueron aquellas herencias culturales de various grupos de inmigrantes europeos? Es más. ¿Qué pasaría si se descubriera que la herencia africana aborigen, en cierto modo, se les había transmitido a los blancos y, así, había convertido el contacto en un intercambio cultural-como lo fue en el caso de otros grupos-en vez de una herencia de una gente inferior con hábitos de un grupo superior? (29-30; traducción mía) 1

Es precisamente esta noción de intercambio de culturas la que parece surgir al escuchar a Adalberto Ortiz, representante por excelencia de lo afroecuatoriano, quien ha comentado:

[...] yo soy mestizo, mi ancestro es negro. Mi abuela era una señora que parecía alemana, tipo colorado, de ojos azules, prima de los Vargas Torres, Concha Torres, y por otro lado, ella era muy amante de todo esto y había sido asimilada por la cultura negra, por eso nos iba muy bien cuando llegábamos a esos puntos de la geografía esmeraldeña.... (Calderón Chico, Tres maestros, 106)
Y aún más pertinente al presente análisis es la afirmación del mismo Velasco Mackenzie, narrador guayaquileño sin raíces aparentemente parecidas a las de Ortiz, quien ha señalado que su novela, Tambores para un canción perdida, "fue escrita en el taller desde la primera hasta la última letra.... Allí... le sacaron el aire al negro Margarito, que fue-es-el personaje central, y al otro negro, el Velasco Mackenzie" (Calderón Chico, "Conversaciones con Jorge Velasco Mackenzie").

Aunque la presencia africana no parezca tan patente en las provincias costeñas ubicadas al sur de Esmeraldas como en el Caribe propiamente, vale recordar que hubo tres momentos claves en la historia de la inmigración de los negros al Ecuador. Se ha señalado que los primeros esclavos llegaron en 1553 debido a un naufragio; luego, los jesuitas del siglo XVII llevaron al país esclavos para trabajar sus plantaciones de caña de azúcar en la sierra; y en la época de Eloy Alfaro (a fines del siglo XIX y a comienzos del XX), llegaron negros de Jamaica, principalmente, para trabajar en la construcción del ferrocarril que iba a unir a Quito con Guayaquil. Más concretamente aún, se ha notado que, para 1830, la mitad de la población guayaquileña era negra (Townsend, sin página), y para fines del siglo XVIII y comienzos del XIX, se ha constatado que en el Ecuador "Negros esclavos había doquier, principalmente en las grandes haciendas del Guayas, Los Ríos, Manabí.... Como no tenían derecho eran explotados...; pero también comenzaron a tener 
conciencia de su situación.... Ellos fueron libres y a pesar de la vigilancia, surgían revueltas, fugas" (Loor Villaquirán 195196). De hecho, esta tradición de cimarronaje que se puede trazar desde la llegada de los primeros esclavos negros al Ecuador en el siglo XVI, seguía alimentándose con el ejemplo de Ambrosio Mondongo en 1789 y Juan José Marques en 1805, "los primeros caudillos de la rebelión de esclavos" (Piedad y Alfredo Costales 63-64).

Si bien es cierto que la historiografía sobre los negros en el Ecuador todavía se encuentra en un estado incipiente, es también cierto que ha habido suficientes investigaciones serias para que el público haya comenzado a tomar más en serio la presencia de lo afro (y sus correspondientes influencias) en la historia nacional. Es así que mientras Juan García ha cuestionado la posibilidad de poner una fecha exacta a la llegada del primer negro al Ecuador, él ha señalado que "Para 1540, es seguro que grupos pequeños de cimarrones vivían en la zona de Esmeraldas, tal vez aisladamente $\mathrm{o}$, tal vez, en contacto con los indios cayapas que habitaban la región" (Collective Memory 7; traducción mía). Por su parte, Leslie Rout, Jr. se ha referido a las migraciones de negros entre Colombia y Ecuador:

Casi desde los tiempos en que los españoles comenzaron a importar a africanos a trabajar en las excavaciones de oro del Río del Cauca en Colombia, los negros han logrado escapar; algunos buscaron refugio entre los indios Manabí y Mantux de la costa tropical del noroeste del Ecuador.
Los descendientes zambos de estos negros e indios llegaron a ser caciques y crearon una importante sede de operaciones de la costa del Pacífico llamada El Portete. Esta fundación en particular se convirtió en una especie de "faro" que atraía a otros esclavos que decidieron fugar en vez de aceptar una muerte en vida, separando el oro en gamella en los arroyos del sur de Colombia. (116; traducción mía)

Con esta base historico-cultural de los africanos en el Ecuador, y recordando a Herskovitz, vuelvo a insistir que ha habido suficientes oportunidades para que los negros costeños influyeran en la composición mestiza del litoral. En vez de haber vivido un proceso paulatino de negación cultural frente a otros sectores dominantes, los negros y sus descendientes de todos los matices habidos y por haber han logrado africanizar ciertas vivencias culturales que distinguen al costeño ecuatoriano de su contraparte serrano. Por cierto, no estoy insinuando que los costeños sean africanos, pero sí estoy reconociendo un pasado vital que hace posible afirmar con Herskovitz que "No hay más evidencia teórica para una hipótesis de que no se ha conservado nada de sus ancestros africanos que de suponer que han seguido siendo completamente africanos en cuanto a su comportamiento" (145; traducción mía). Por consiguiente, no parece una mera casualidad que entre los ecuatorianos es solamente al pícaro y vivaracho costeño, y sobre todo al guayaquileño, a quienes se les identifica como monos. Aunque puede haber mucha especulación sobre su origen en el Ecuador, "the signifying monkey" 
aparece en todas las culturas afroamericanas y se supone que está vinculado a la figura del "Pan-African trickster, Esu-Elegbara" (Gates, The Signifying Monkey... 88 ), que en el Caribe, este "smartman... is a pícaro trickster, the ultimate cimarrón (maroon)" (Smart, Nicolás Guillén: Popular Poet of the Caribbean, 95). Por todo esto, se puede entender porqué Antonio Preciado, importante poeta esmeraldeño, ha afirmado que es inconcebible pensar en la literatura afroecuatoriana como un campo exclusivo de los negros (Kutzinski 34-35).

La observación de Preciado ha de leerse de dos maneras. Por un lado, el escritor negro debe sentirse plenamente libre y con plena autoridad para escribir sobre cualquier tema. Por otro lado, no hace falta ser de Esmeraldas para reconocer que el Ecuador es un país multiétnico en el cual lo africano, de una manera u otra, pertenece a todos los ecuatorianos. Hay que reconocer que hasta la cumbia es un baile que combina armónicamente elementos indios y africanos (Kutzinski 26).

No ha de ser extraño, entonces, que un escritor costeño haya reconstruido la historia nacional a partir de las experiencias de un cimarrón negro y de diversos referentes historico-míticos anclados en tradiciones africanas, aunque remotas y lejanas. Con Tambores para una canción perdida, Jorge Velasco Mackenzie ha roto, por una parte, aquellos esquemas tradicionales que han relegado lo afroecuatoriano a la provincia de Esmeraldas y, por otra parte, él ha contrarrestado un falso mestizaje nacional que, hasta la fecha, sólo ha esfumado la vigencia de ciertas tradiciones africanas venidas de Colombia, Panamá, las Antillas y Africa. Es decir, aunque algunos quisieran tergiversar la discusión, insistiendo que lo afroecuatoriano ha sido plenamente reconocido e incorporado en lo nacional (y para comprobarlo se señalaría a tales figuras eminentes como Adalberto Ortiz, Nelson Estupiñán Bass y Antonio Preciado), la innovacion de la novela de Velasco radica en su capacidad de haber ayudado a reconsiderar el lugar que ocupa lo africano en el conjunto multiétnico del Ecuador. ${ }^{2}$ En cierto sentido, Tambores para una canción perdida es lo que Iser clasificaría como "la recodificación literaria de normas históricas y sociales [que] tiene una doble función: permite que los participantes-o los lectores contemporáneos [de la escritura]vean lo que no pueden ver normalmente en el proceso común de la cotidianidad; y permite que los observadores-las generaciones subsiguientes de lectores-capten una realidad que nunca les había pertenecido" (74; traducción mía).

Este proceso de recodificación, con su "doble función" que Iser ha planteado, ayuda a comprender lo que, a primera vista, parece ser una contradicción en la novela. Por un lado, se escucha al protagonista (Margarito, el cantador), quien reclama a Iris, un personaje enigmático que pertenece simultáneamente al mundo terrestre de los esclavos y al panteón de los dioses africanos, advirtiéndole: "Deja ya de invocar a Changó que está dormido en su ra- 
ma, no es nuestro dios..." (23). Por otro lado, sin embargo, se le aconseja al cantador que "antes de dar el primer paso para alejarte recuerda tus tradiciones..." (85). Es así que sale a flor de piel la tensión que Velasco resalta dentro de la experiencia ecuatoriana al buscar un equilibrio entre la necesidad de conocer y aceptar su pasado ("recuerda tus tradiciones") y el descubrimiento de que este pasado ha asumido nuevos matices ya que Changó, propiamente, es de otros. En lo que respecta a los lectores de Tambores para una canción perdida, Velasco parece estar desafiándolos a ser sensibles y receptivos frente a las complejidades de la presencia negra en el Ecuador. De hecho, según él escribe: "Hay un río de aguas benditas que... los habitantes del valle de los Chillos lo adoran como a un oricha y lo llaman San Pedro, el nombre blanco de Changó" (36).

Curiosamente, esta obra de Velasco que había ganado en 1985 El Premio Nacional de Novela "Grupo de Guayaquil," y que según un crítico, desde ahora en adelante, constituirá un punto de partida de cualquier "novela que dé cuenta del esclavismo, de los ritos africanos en el Ecuador" (Balseca 48-49), ha sido víctima de su naturaleza iconoclasta y, por lo tanto, se la ha malentendido. Huelga recordar que poco después de una entusiasta recepción inicial, Velasco fue acusado de haber plagiado a Laura Hidalgo, autora de Décimas esmeraldeñas. Hubo una serie de denuncias y réplicas, contrarréplicas y explicaciones; y hasta Alfredo Pareja Diezcanseco, jurado del premio de novela que se le había otorgado a Velasco, lamentó públicamente haber participado en tal fallo.

Al mismo tiempo, Tambores para una canción perdida iba a hundirse directa o indirectamente en otra maraña de controversias por haber sido el producto de un taller literario. Conceptos de creación y de originalidad artísticas se discutieron y, con todo lo que se había declarado respecto al supuesto plagio, la suerte de esta novela fue irreversiblemente echada-se perdió en el silencio y en el olvido.

En cuanto a las denuncias de un plagio, no se debe olvidar que a veces la distinción entre la originalidad y la copia es ambigua e incierta. No es tan fácil determinar cuáles son los temas y figuras poéticas que ya pertenecen a todo el mundo y, por lo tanto, no requieren mención especial. De hecho, Zora Neale Hurston ha puntualizado que "lo que realmente queremos decir con originalidad es, en efecto, revisión ejemplar, porque 'originalidad es la modificación de ideas.' Con la modificación de ideas, Hurston quiere decir 'reinterpretación"' (Gates, The Signifying Monkey... 118; traducción mía). Es así que yo creo que Velasco Mackenzie más bien optó por trabajar con una serie de tópicos de diversas literaturas afroamericanas mientras que buscaba un mundo poético que intencionadamente oscilaba entre la historia y el mito (Calderón Chico, "Conversaciones con Jorge Velasco Mackenzie"). Es precisamente este juego entre historia y mito donde se patentiza la originalidad de Tambores para una canción perdida.

Los referentes históricos sitúan al texto en el Ecuador. La llegada de los pri- 
meros esclavos, la población llamada Pidi que fue uno de los primeros sitios donde los esclavos se establecieron, el Cristo Negro de Daule, la presencia de Eloy Alfaro y el incendio de Guayaquil son del saber común nacional. A la vez, la apropiación por Velasco de diversos orichas africanos, el empleo de los tambores como medio de comunicación, las alusiones a un sacerdote defensor de los esclavos y el recurrir a un cimarrón para establecer un eje novelesco insertan a la novela en una tradición panafroamericanista. Dentro de este proceso de intertextualidad donde Tambores para una canción perdida recuerda a tales obras como El reino de este mundo, Juyungo, Changó, el gran putas, Raíces y Biografía de un cimarrón, no se descubre un intento de plagiar sino un esfuerzo por recoger y (re)interpretar experiencias de una diáspora que millones de personas han compartido en todo el continente. En este sentido, se ha señalado que "modos de figuración comunes resultan solamente cuando los escritores se leen entre sí y se apropian de topos y tropos para revisar sus propios textos. Esta forma de revisión es un proceso de establecer bases de creación y ha servido para generar curiosas líneas formales de continuidad entre los textos que en su conjunto componen el texto común de la negritud..." (Gates, The Signifying Monkey... 128-29; traducción mía).

Sin duda alguna, esta última referencia a "una continuidad entre los textos... de la negritud" es una constatación más de la vitalidad de la diáspora afroa- mericana, una diáspora que incluye al Ecuador. Huelga recordar que

[...] la mayoría de los afroecuatorianos tienen su origen en las sociedades mineras de Barbacoas, Iscuandé y Tumaco, que en la Colonia pertenecían a Popayán. Esto lo confirma la toponimia de la región del río Cayapas y Onzole (Esmeraldas), ratificando que las fronteras en este caso son arbitrarias y artificiales; pues dividen a las comunidades de un mismo origen, sin tener en cuenta la unidad del pueblo negro, descendientes de los africanos que trabajaron en las haciendas y las minas del Litoral Pacífico. (Jurado Noboa 1920)

Puesto que mucho queda todavía por investigar y precisar en lo que respecta a lo afroecuatoriano, especialmente si se piensa más allá de Esmeraldas, Velasco Mackenzie ha fusionado mitos africanos de diversos orígenes para, así, crear la misma ambigüedad y el mismo estado enigmático que caracterizan gran parte de los conocimientos actuales de lo afroecuatoriano frente a lo nacional y, a la vez, frente a la diáspora. De hecho, no se ha de olvidar que la canción que Velasco quería cantar se había perdido. Por lo tanto, luego de partir de datos concretos sobre el negro en el país, él se sirvió de la imprecisión de los orígenes y de las fuentes de diversas leyendas y tradiciones para sugerir nuevas posibilidades de lectura y de comprehensión. $\mathrm{Al}$ respecto, Iser ha comentado:

He aquí la relación singular entre el texto literario y la "realidad," a manera de siste- 
mas de pensamiento o modelos de realidad. El texto no los copia, ni tampoco se desvía de ellos [...]. En cambio, representa una reacción a los sistemas de pensamiento que ha escogido y que ha incorporado para su propio repertorio. Esta reacción es impulsada por la habilidad limitada del sistema de hacer frente a la diversidad de la realidad y, por consiguiente, pone al descubierto sus deficiencias. El resultado de esta operación es el reordenamiento y, en efecto, la rejerarquización de los patrones existentes de los significados. (72; traducción mía)

Por lo tanto, la fragmentación, los múltiples narradores y la confusión entre historia y ficción, obligan al lector de Tambores para una canción perdida a poner orden a un mundo aparentemente caótico. Pero, curiosamente, se descubre que todo intento de establecer dicho orden termina resaltando la arbitrariedad de las interpretaciones $y$, a la vez, los vacíos de la historia nacional que se esperan llenar. La fuga de Margarito, el cimarrón negro de la novela que busca la libertad y la verdad, se convierte en la experiencia del lector que comprende que no puede haber la verdad sin libertad, ni libertad sin la verdad. Por eso, en la novela se lee:

Vivimos en... medio de un nudo de palabras que ocultan el principio, como en un ovillo al que hay que buscarle la punta; desenredas desenredas sin encontrarla, sin hallar el punto donde todo se ha iniciado para después irse enredando, tejiendo la maraña de sucesos que son las verdades, marañas sobre las palabras, torpes palabras que a veces no dicen nada cierto; ahí están tu historia y la mía, haciéndose nudos, amarrándose fuertemente para que nadie pueda desatarlas, dejarlas libres para que alguien las repita, vuelva a enredarlas contando otras historias, más intrincadas todavía, ocultando siempre el principio que es en realidad donde está el final. (73)

No hay duda de que esta novela de Velasco Mackenzie es también un nudo de palabras que se niega a desenredarse por completo. Y, por consiguiente, cada lectura revela una nueva sorpresa, una nueva verdad, que recuerda al lector que la historia del Ecuador es también múltiple, fragmentada y caótica. En el mismo sentido de la novela-o de ese nudo de palabras, la historia nacional contiene todos los componentes necesarios para que se los descubra eternamente. Al final de Tambores para una canción perdida se advierte que "la canción nunca estuvo perdida, la tienes frente a ti, hecha el hombre que ves, cuenta su historia ya que no puedes cantarla, ni saber lo que dicen tocando los tambores que hablan lengua" (157).

De acuerdo con mis lecturas de Tambores para una canción perdida, uno de los mensajes fundamentales de Velasco Mackenzie está claro. Lo que se necesita saber está ahí, frente a todos, pero siempre inalcanzable. En vez de postrarse en un estado de frustración, sin embargo, la ambigüedad bien entendida sirve como catalizador de un constante cuestionamiento, de una constante acción. Por eso, Iser ha argumentado: "Si el lector y el texto literario son compañeros en un proceso de co- 
municación, y si lo que se comunica va a tener algún valor, nuestra principal preocupación no será sobre el significado de ese texto... sino sobre su efecto. He aquí la función de la literatura..." (54).

¿Cuál es el efecto, entonces, de Tambores para una canción perdida? Obliga al lector a revalorar el papel medular que ha jugado, y que sigue jugando, una herencia africana de muy diversos matices que vincula al Ecuador y, sobre todo, a la Costa ecuatoriana, a un circuito cultural panafricanista que a su vez incorpora, de una manera u otra, a toda América. En el caso concreto del Ecuador, al plantear la centralidad de lo africano en el conjunto multiétnico y plurinacional del país, Velasco supera una tradición reduccionista fenotípica para, así, insistir que raza y etnia se caracterizan según sus contenidos culturales y la medida en que uno se identifica con ellos. El "negro Velasco"- para emplear sus propias palabras ya citadas-no es negro por el color de la piel sino por tener raíces en Jamaica, por tener como suya la música salsa, por saber orgullosamente que como, "mono guayaquileño," él lleva muy adentro la tradición del oricha africano, Elegba, aquel dios pícaro cuya relación con el destino "está inscrita en su papel como la fuerza orientadora de la interpretación misma" (Gates, The Signifying Monkey... 23; traducción mía). Es decir, "'A Elegba le designaron el rol de lingüista entre los reinos de dioses y dioses, y de dioses y hombres. Entonces, además de saber la 'lengua' de Mawa-Lisa, le hicieron entender todas las 'lenguas' ha- bladas por los otros dioses en sus respectivos dominios..."' (Gates, The Signifying Monkey... 23-4; traducción mía). De modo que en Tambores para una canción perdida, Velasco Mackenzie escucha la música lejana del "Tan Tan" (expresión de Adalberto Ortiz) y, al interpretarla, él crea una canción que es a la vez antigua y nueva, de tiempos y tonalidades distantes y cercanos, desconocida y conocida, perdida o silenciada inconsciente o conscientemente. En fin, esta canción de Velasco Mackenzie rescata unos acordes que no han de faltar si se espera aprehender plenamente aquel coro de diversas voces y culturas que es el Ecuador.

\section{Notas}

1 El texto original es así: "But what if the estimate of Africanisms is not correct? What if these cultures [of Africa from which the New World Negroes were derived] impressed themselves on their carriers, and the descendants of their carriers, too deeply to be eradicated any more than were the cultural endowments of the various groups of European immigrants? More than this, what if the aboriginal African endowment were found, in certain respects, even to have been transmitted to the whites, thus making the result of contact an exchange of culture-as it was in the case of other groups-rather than the endowment of an inferior people with habits of a superior group?"

2 Si se toma en cuenta el capítulo anterior sobre los escritores del Grupo de Guayaquil, se ven claramente algunos de los vínculos entre Velasco y ellos (especialmente, Cuadra y Gil Gilbert). En efecto, la originalidad de la novela de Velasco no viene del tema tratado, sino de la manera "abierta" y multifacética de haberlo presentado. 


\section{Capítulo IV \\ Lo afro, la costa y la plurinacionalidad del Ecuador: Un tríptico visto a partir de Viajando por pueblos costeños, de Jorge Martillo}

\begin{abstract}
“¿Híbrido o nuevo hombre? ¿Soy realmente un traidor a mi raza? ¿Un zambo escurridizo? ¿Un mulato entreguista? O sencillamente un mestizo americano que busca defender la identidad de sus sangres oprimidas." (Manuel Zapata Olivella, Levántate mulato)
\end{abstract}

La relación entre lo afro, la Costa y la plurinacionalidad del Ecuador tiene resonancia en el epígrafe de arriba donde se resalta gran parte de la polémica sobre las identidades heterogéneas y la búsqueda de una unidad nacional capaz de reconciliarse con dicha diversidad. Aunque mi interés aquí apunta primordialmente hacia la situación en el Ecuador, parto de una reflexión hecha por un escritor colombiano para constatar que el tema que se elaborará a continuación trasciende fronteras $y$, sobre todo, constituye un desafío conceptual en los países andinos cuya tradición indomestiza ha opacado a menudo sus vivencias de origen africano. De hecho, $\mathrm{Za}$ pata Olivella pone en tela de juicio el concepto mismo del mestizaje latinoamericano ya que éste tiende a eliminar del esquema nacional aquellas tradiciones étnicas que han sido consideradas más próximas a la "barbarie" que a la "civilización." Los estudiosos sobre lo afrolatinoamericano que han definido el mestizaje como un proceso de "blanqueamiento" ya son legión. Negar las herencias africanas en nombre de la unidad nacional se ha convertido en una política de manipulación y distorsión programada para construir una nacionalidad "eficaz" que desgraciadamente tiene su base en una homogeneidad mítica destinada a producir sistemas injustos debido a su racismo inherente. Por eso, Zapata Olivella se pregunta hasta qué punto le es posible a uno aceptar su condición de "mestizo americano" sin perder de vista (es decir, "defender" y "celebrar" a la vez) sus diversos componentes étnicos.

\section{A propósito de Viajando por pueblos costeños de Jorge Martillo Monserrate: Una hipótesis}

Esta pequeña introducción sirve para matizar importantes aspectos del debate sobre el plurinacionalismo en el Ecuador. He de señalar que el enfoque principal, tanto de los que han defendido el carácter mestizo del Ecuador (sin dejar de insistir en una supuesta superioridad his- 
pánica, claro está) como de los que han destacado el carácter plurinacional del Ecuador, se ha anclado en los sectores indígenas del país. Por una parte, ha sido "común en la interpretación de la realidad nacional, la concepción del Estado Ecuatoriano integrado por una sola cultura nacional, la cultura nacional, que se origina en la nacionalidad mestiza hispano hablante y con manifestaciones de culturas periféricas indígenas aborígenes que se estructuran en torno a ésta" (Coba 19). Por otra parte, mientras que "investigaciones recientes... han permitido llegar a la conclusión y/o comprobación... que el Ecuador es un estado Multinacional y Heterogéneo" (Coba 19), se ha puntualizado que

la presencia de nacionalidades diversas no significa que aquí en el Ecuador hay varias Naciones o mucho menos varios Estados; sino buscar la afirmación de los diversos pueblos que constituyen el país buscando normas de respeto a sus particularidades, lo cual más bien consolida la unidad. Vale decir, por fin, que el propio contenido del término que define a las nacionalidades indígenas se irá enriqueciendo conforme éstas encuentren formas autónomas de desarrollo. (Ayala, de la Cruz, et al., 39)

Aunque la intención del discurso sobre la heterogeneidad nacional (patente en esta última cita) busca una apertura hacia una participación más democrática en el país, huelga reconocer ciertas limitaciones en su concepción, por lo menos, en lo que se refiere a los ecuatorianos de origen africano. La exclusión de lo afroecua- toriano no es un fenómeno nuevo. Leslie B. Rout, Jr. ya ha observado, por ejemplo:

Entre 1954 y 1958 se realizaron veinticinco estudios y programas de ayuda en el Ecuador para mejorar la condición socioeconómica de la población india. Como contraste, no se creó ningún programa para ayudar al afroecuatoriano. Como en Perú, la condición de la población india es el problema más saliente, y así es que la minoría afroecuatoriana es sencillamente ignorada. Pero, a diferencia de la situación en Perú, personas de origen africano son la mayoría, por lo menos en una provincia, y una minoría numerosa en otras tres.... (235; traducción mía)

No ofrezco esta acotación con el afán de minimizar las injusticias sufridas por los indígenas del Ecuador, ni tampoco deseo debilitar posibles proyectos de solidaridad que puedan surgir entre diversos grupos de gentes oprimidas del país. Sin embargo, hace falta seguir insistiendo en la amplitud de la cuestión plurinacional ya que el Ecuador, país andino, traspasa geográfica, económica, política y culturalmente las cordilleras. Norman E. Whitten, Jr. logra resumir claramente algunas de las contradicciones inherentes a muchos intentos por definir "lo ecuatoriano."

La gente étnicamente "no-nacional," especialmente la población afro-hispánica de la zona tropical del noroeste de la costa del Ecuador y del sur de Colombia, y las poblaciones indígenas del Ecuador amazónico, son generalmente excluidos de una participación directa en la planificación de cambios en su habitat. El esfuerzo 
en el Ecuador por nacionalizarse, con su centralización de contrapunto entre Quito y Guayaquil, parecido al de naciones hermanas que luchan en plena dependencia euro-americana, a menudo proclama una ideología de homogeneización étnica. El producto de la homogeneización se llama, a veces, el hombre ecuatoriano, pero se contradice esta promesa de "inclusión" como "el hombre ecuatoriano" con una insistencia en la supremacía blanca. El proceso práctico de excluir a los que son considerados no mezclados es llevado a cabo por la gente misma que sostiene una ideología de inclusión basada en la mezcla racial, el mestizaje, y la contradicción que resulta les es obvia tanto a los ecuatorianos étnicamente identificables como costeños negros y serranos negros como a la gente indígena del Ecuador. Además, las propuestas superficialmente inclusivas de la ideología del mestizaje se minan, aún más, mediante una cláusula tácitamente calificativa que aumenta el precio de admisión de una mera "mezcla fenotípica" al blanqueamiento cultural ("blanqueamiento," en términos de hacerse más urbano, más cristiano, más civilizado; menos rural, menos negro, menos indio). Esto complica la contradicción por generar contínuamente disensión y dissensus internos dentro de "categorías mixtas." (Cultural Transformations and Ethnicity in Modern Ecuador 15; traducción mía)

Me he permitido reproducir in extenso estas observaciones de Whitten porque en ellas se vislumbran algunas de las ideas que se desarrollarán a continuación, a saber, la ubicuidad de lo afro en el Ecuador, la superación de un concepto nacio- nal concentrado casi exclusivamente en los Andes y el "blanqueamiento" como un proceso de etnocidio. Pero a diferencia de Whitten y a otros investigadores que han escrito sobre lo afroecuatoriano, el mestizaje y la identidad nacional, yo quisiera ampliar más el concepto de lo afroecuatoriano. Es decir, mi análisis no se detiene en Esmeraldas, provincia afroecuatoriana por excelencia, ni se dirige primordialmente a aquellos grupos fenotípicos que todo el mundo sigue considerando negros y al margen (geográfica y culturalmente) de la sociedad mayoritaria del Ecuador. Dicho de una manera más concreta, pretendo destacar lo afro como una fuente medular en la construcción de una cultura costeña que a su vez pone en tela de juicio el concepto mismo que tradicionalmente se ha empleado para definir al Ecuador como país andino.

Al comentar Tambores para una canción perdida de Jorge Velasco Mackenzie, aludí al lugar que lo afro ocupa en la historia nacional, por lo menos según la perspectiva de un escritor costeño. Mi interés en la relación que existe entre lo afro y la Costa coincide con el trabajo afrocéntrico que otros investigadores están realizando en tales países vecinos como Colombia, Perú y Venezuela. En su estudio, Blackness and Race Mixture: The Dynamics of Racial Identity in Colombia, Peter Wade pone de manifiesto un enfoque parecido al mío en lo que respecta al Ecuador: "Mi propósito no es trazar retenciones africanas, sino destacar cómo la cultura negra se ha manifestado tan claramente en la Cos- 
ta. Los negros desarrollaron una tradición de resistencia que creció junto a, y luego, se unió a la resistencia de indios y mestizos pobres" (91; traducción mía). En el campo de la crítica literaria propiamente, Marvin Lewis también ha empleado un instrumento afrocéntrico de análisis para así establecer aquel equilibrio tan patente en las palabras de Zapata Olivella que aparecen en el epígrafe de este capítulo. Según Lewis, en cuanto a los escritores que él ha analizado, su propósito no ha sido el de negar "su ancestro colombiano o su nacionalismo cultural, sino el de señalar lo positivo de las influencias de su herencia africana en sus estrategias literarias. En la mayoría de los casos, no se ha tomado en cuenta este último aspecto, en parte porque estos escritores no escriben exclusivamente sobre la experiencia negra en Colombia" (Treading the Ebony Path: Ideology and Violence in Contemporary AfroColombian Prose Fiction 1; traducción mía).

Por lo tanto, si los análisis acerca de lo afroecuatoriano siguen reduciéndose a una sola provincia o a un solo fenotipo, se producirá inevitablemente una deslegitimización de lo afro en el esquema nacional. ${ }^{1}$ Además, al insistir en definir lo afro solamente en términos fenotípicos, se core el peligro de desvirtuar importantes vivencias de la Costa ecuatoriana. De hecho, hay que recordar que no ha sido raro que la Costa del Ecuador haya sido descrita según sus diversos rasgos supuestamente caribeños. Reconocer elementos caribe- ños como constitutivos del vivir costeño del Ecuador es aceptar tácitamente, por lo menos, que la Costa ecuatoriana en no poca medida es una extensión vital de lo afrolatinoamericano.

Esta identificación con lo afro en la Costa sale a flor de piel en Viajando por pueblos costeños (1991) del poeta y cronista guayaquileño, Jorge Martillo Monserrate. No interesa aquí si Martillo es o no es negro, mulato, mestizo, trigueño o cualquier otro calificativo racial. Lo destacable, más bien, es el reconocimiento que hace un escritor costeño sobre la importancia cultural de lo afro y cómo lo ha internalizado, demostrando la medida en que lo afro ha trascendido la provincia de Esmeraldas.

Además de poeta, Martillo se ha distinguido como uno de los intérpretes más agudos de la cultura popular de Guayaquil. Sus crónicas publicadas principalmente en El Universo de Guayaquil revelan un profundo cariño, respeto y entendimiento de aquellas gentes a quienes la sociedad oficial ha relegado a los márgenes-socioeconómicos, sociopolíticos, socioculturales-de la gran urbe guayaquileña. En efecto, Martillo tiene la capacidad de descubrir y de apreciar la vitalidad y la creatividad de aquellas gentes a quienes los detentadores del poder preferirían borrar de la vista cuando no de la memoria. Por estar Martillo más cerca al Calibán de Fernández Retamar que al Ariel de Rodó, no extraña que la Costa que se vislumbra en las páginas de Viajando por pueblos costeños no pertenezca a las imágenes predi- 
lectas del turismo burocrático y oficial de algún Ministerio más interesado en atraer a clientes que en conocer cabalmente lo que no aparece en sus folletos y panfletos. La Costa de Martillo es la que se vive todos los días con sencillez, modestia y constancia frente a las penurias y dificultades que el turismo oficial insiste en encubrir. Esta aclaración es de suma importancia puesto que ayuda a explicar por qué la Costa de Martillo vibra con todo su carácter caribeño, con toda su vitalidad afroecuatoriana. Mientras que otros intérpretes carecen de la sensibilidad o la voluntad necesaria para ir más allá de conceptos trillados y parciales, Martillo se acerca espontáneamente y con entusiasmo a esas verdades que son visibles a los que realmente desean conocerlas.

Lo primero que llama la atención al leer Viajando por pueblos costeños es la prevalencia de Esmeraldas y Guayaquil. En cierta manera estos dos centros constituyen el meollo conceptual e interpretativo del litoral ecuatoriano según la visión de Martillo. Por su tamaño e importancia política y económica, es lógico que gran parte de toda interpretación de la Costa encuentre en Guayaquil, el puerto máximo del país, una especie de microcosmos costeño. En lo que respecta a Esmeraldas y la manera como Martillo la trata al comentar su recorrido por la Costa ecuatoriana, el lector atento comienza a intuir asociaciones sorprendentes entre lo afro y lo nacional por un lado, y estas dos zonas por otro.

Martillo inicia su texto mientras viaja hacia Esmeraldas. Si bien se podría asumir que la selección del orden de materiales y la presentación de los mismos están de acuerdo con la geografía-es decir, que son desarrollados siguiendo simplemente los caminos que se toman desde el norte hacia el sur del litoral, es también posible entrever una intencionalidad más de fondo. De hecho, Martillo escribe: "El bus devora distancia, acercándonos a nuestros orígenes" (33). Esta idea de retorno aparece en varios momentos dentro de las reflexiones que el autor hace acerca de Esmeraldas. No es difícil captar las afinidades profundas que Martillo, observador guayaquileño, siente por esa provincia definitoria. Sin un afán de estereotipar o de folklorizar a los esmeraldeños, convirtiéndolos en unos "buenos salvajes" congelados en un tiempo histórico inexistente, Martillo pone de relieve un mundo en constante evolución que corre el peligro de perder sus vivencias originarias mientras continúa marchando dentro de una modernidad de exclusión y omisión. Las crónicas sobre Esmeraldas de este libro incluyen información histórica (la fundación de la provincia), antropológica (las costumbres), económica (la pobreza, sobre todo) y política (las relaciones con un gobierno centralista y distante). Consecuente con su identificación con los sectores populares del país, Martillo deja que los mismos esmeraldeños hablen de sus tradiciones y analicen su propio entorno. Es dentro de este ambiente de diálogo donde se descubre que junto a un interés por conocer e informar, la verdadera atracción que Esmeraldas tiene sobre Martillo radica en su larga historia de re- 
sistencia y de creación. Por eso él escribe: "Hacia aquellas tierras, donde no se aceptaba la servidumbre, fueron a parar otros cimarrones que huían de mercaderes blancos. Arribaban desde tierras norteñas de la actual Colombia, incrementando una población que se orgullecía (sic) de sus libres orígenes" (34).

De manera que, para Martillo, en el esquema nacional Esmeraldas juega un papel que va más allá de la cuestión estrictamente racial. Todo ecuatoriano puede encontrar en la provincia esmeraldeña un espíritu rebelde que pertenece a todo el país. Esta amplitud de criterios en cuanto a la evaluación del afroesmeraldeño dentro de la construcción nacional se vislumbra aún más cuando Martillo puntualiza: "Al llegar los tiempos de la lucha independentista, los negros y mulatos engrosaron tropas combatientes.... De negros y mulatos procede una rica poesía popular, cantos y bailes folclóricos que caracterizan la vida cultural de Esmeraldas, que se han extendido por todo el país" (34; lo subrayado es mío). La clave aquí es la noción manifiesta de una presencia ubicua de lo afro en el Ecuador que en no poca medida saca lo afro de los márgenes de lo nacional. Ya no se trata de curiosidades culturales o accidentes históricos. Lo afroecuatoriano se convierte en uno de los baluartes de la nacionalidad ecuatoriana.

Es así que Martillo ha afirmado: "Hemos llegado, no tras piedras preciosas que se encontraban en estos ríos verdosos y que hacían delirar a españoles. Hemos llegado a nuestros orígenes" (35). Implícita en esta última observación está la idea de que Martillo ha logrado trascender las señales superficiales y puramente decorativas que tradicionalmente han reducido lo afro en el Ecuador a una cuestión de exotismos y aberraciones raciales. Con un buen oído, Martillo ha escuchado a la gente; con los ojos bien abiertos, él la ha observado. Según le habían explicado en Esmeraldas, hacia el norte de la provincia, "'aún los viejos tocan la marimba y glosan de lo bello, pero poco a poco van muriendo, llevándose todo a la tumba. Hay que rescatar nuestra memoria, hay que rescatar y reproducir nuestras raíces. Si no luego qué seremos: un pueblo sin cultura" (42). Dentro de la concepción que Martillo tiene de lo afro en el Ecuador, esta advertencia constituye una voz de alerta para todos los ecuatorianos. Es decir, la experiencia de los afroesmeraldeños-el peligro de perder la memoria, por ejemplo- les pertenece a todos aunque sea de maneras diversas.

De modo que el viaje de Martillo a Esmeraldas lo ha llevado a lo suyo. En el momento de establecer una identificación con lo afroesmeraldeño, lo cual ha permitido que la negritud no ofusque la nacionalidad ecuatoriana y que ésta no niegue lo afro de la provincia, se vuelve con Martillo a Guayaquil—al Guayaquil de los Guasmos (los barrios marginados de la ciudad), naturalmente-donde ya libres del peso de la tradición oficial aburguesada se siente vibrar lo afro como si se estuviera todavía en Esmeraldas. Escribe Martillo:

El Viejito ha descubierto que en cierto lo- 
cal la rumba está que arde.... El dueño del bar debe ser esmeraldeño por el son montuno que bailan negros y mulatos. Mujeres bellas marcan el paso, espuma de cerveza que adorna las mesas, pomos helados, vasos repletos del amarillo bielero. El volumen alto: "Llegó el sonero del amor/esto que les traigo, sí tiene sabor./Esto que les traigo, sí tiene sabor./Soy un sonero que canta a las mujeres bonitas." (190)

Con Martillo, se intuye que Guayaquil y Esmeraldas no son tan distintas ni están tan distantes la una de la otra. Uno comprende que se trata de la Costa: "Dante coquetea con una sirena chola.... La salsa salpica notas y sones. El Viejito pide otra porque en repetir está el contento. En la Playita de Miami del Guasmo se hace la noche, pero no importa. ¡Salud!” (19091).

Con la ayuda de su sensibilidad poética y su afán por participar plenamente en el mundo complejo de las mayorías de su ciudad, de su región y de su país, en su recorrido por la Costa, y en especial por Esmeraldas y Guayaquil, Martillo revela una cultura que en no poca medida responde a un mismo sistema de movimientos, sonidos e imágenes. La flauta andina queda muy lejos de estas tierras en las que hablan primordialmente la marimba, la guasá y el cununo. En este sentido, Martillo ve en Esmeraldas mucho más que un mundo aisladamente afro cuya identidad se debe principalmente al color de piel de la gente. Esmeraldas es donde nació la Costa, es donde toda una historia de luchas por la libertad y la justicia se descubrió y creó su propia expresión, no como antítesis o negación de parecidas y diversas historias de los Andes, sino como su complemento. Viajando por pueblos costeños coloca a Esmeraldas en el centro mismo del vivir y sentir costeños. Para Martillo, viajero guayaquileño, no hay duda sobre sus orígenes. En toda esa panoplia cultural que constituye la Costa ecuatoriana, la presencia afro sigue vibrando enérgicamente. Sin Esmeraldas, el Guayaquil que Martillo siente con tanta pasión sería otra ciudad, sería una ciudad menos caribeña, menos costeña, menos ecuatoriana.

\section{Lo afroecuatoriano más allá de Esme- raldas}

Puesto que la presencia de lo afro en la historia del Ecuador ha sido sometida a un proceso de blanqueamiento y de marginalización, no se acostumbra tratar con la necesaria amplitud de criterios el tema de Africa con sus múltiples matices que aparecen a lo largo y a lo ancho de toda América. Por eso, la apropiación y la asimilación culturales que hace Martillo de lo afroecuatoriano corren el riesgo de no valorarse plenamente. Ante un escepticismo tradicional (por no decir una negación) de la importancia de lo afro en el país, vale recordar una vez más que el componente afro de la nacionalidad actual del Ecuador llegó a la costa ecuatoriana en el siglo XVI y no ha dejado de evolucionar desde entonces. Es decir, aunque la cultura afroecuatoriana no se ha caracterizado por los mismos vínculos patentes con Africa que han estado y que están todavía omnipresentes en Brasil, Cuba y Haití, por ejemplo, no se ha de descartar 
sin más ni más la herencia cultural de lo africano en el Ecuador. Nelson Estupiñán Bass ha señalado que "La marimba, transplantada de Africa, vino en el bagaje espiritual del negro, junto a sus dioses, sus danzas, sus canciones, sus panoplias" (Desde un balcón volado 55). El poeta Antonio Preciado también reconoce la vitalidad de algunas herencias africanas en el Ecuador. A pesar de muchos de los obstáculos que siguen negando su existencia, Preciado ha observado en una entrevista con el mismo Jorge Martillo Monserrate:

Si te refieres a la ascendencia africana, eso se pierde de vista. Los negros ecuatorianos, y hablo particularmente de los esmeraldeños, no hemos podido rastrear estos antecedentes. Dudo que en otros lugares del país, como en el Chota o en Loja, se haya logrado. Tenemos noticias muy remotas y casi perdidas de estos antecedentes pero no muy ciertas. Estudios realmente serios no se han realizado, y duele porque conozco pueblos negros que mantienen viva su lengua y elementos africanos en su vida diaria. Lo que he recibido, por mis abuelos y mis padres, son usos y costumbres, como la medicina de la yerba, que era a la que se recurría. Cuando era muchacho yo tomaba esas abluciones. Todo ese mundo mágico al que yo respeto, que va dentro de mí y del que nunca he podido ni querido sacudirme y al que le tengo una sincera reverencia. ("El poeta les muestra sus raíces" 11 )

Por su parte, el investigador Leslie Rout, Jr., ha identificado un proceso paulatino y constante en que gente de origen negro ha participado en la formación na- cional, especialmente durante el siglo XIX. Según ha puntualizado,

en 1835 los colombianos comenzaron a vender calladamente sus "piezas de ébano" que ya no querían a clientes peruanos, y Ecuador se convirtió en una estación de abastecimiento y en un centro de reembarque para tal comercio. La presión británica instó a Juan José Flores a firmar un tratado contra la esclavitud en 1841, pero el congreso nacional tardó cinco años en ratificar el acuerdo; cualquier efecto que las restricciones hubieran tenido en la trata de esclavos fue ceremonial. (228; traducción mía)

Rout también se ha referido a la época de José María Urbina de mediados del siglo XIX (1851-1856): "Al haber tomado el poder en 1851, Urbino (sic) se encontró sin suficientes tropas, un requisito si él esperaba retener el control sobre su país combatido. Urbino (sic) no sólo comenzó a reclutar a ex-esclavos para su ejército, sino que estableció una fuerza especial de negros, el batallón Taura, que ganó una reputación nefasta por realizar ataques de terror contra los enemigos del poder" (230; traducción mía). Finalmente, Rout constata que el Ecuador "ha sido una de las pocas naciones latinoamericanas que había permitido la inmigarción de negros libres.... La insistencia británica y la necesidad de una mano de obra barata para la construcción del ferrocarril y las minas de oro produjeron un cambio parcial de política, y por lo menos, 4.000 trabajadores jamaiquinos eventualmente se radicaron en el país" (230-31; traducción mía). ${ }^{2}$ 
De los comentarios citados de Estupiñán Bass, Preciado y Rout, se puede desprender que la exclusión del negro como componente integral de la nacionalidad ecuatoriana se debe más al desconocimiento de él (sea esto consciente o inconsciente por parte de las mayorías de la sociedad) que a su supuesta ausencia. Cuando Preciado lamenta la falta de "estudios realmente serios" sobre lo africano en el Ecuador, se entiende que existe algo que investigar y resaltar. Sin duda alguna, el caso ecuatoriano refleja lo que sucede en muchos países donde la valoración de lo afro se ha estancado a través de los siglos en un sinnúmero de imprecisiones y distorsiones. Es así que Winthrop Wright ha señalado que pese a la condición híbrida de Venezuela que incluye lo europeo, lo indígena y lo afro, ha sido solamente desde apróximadamente la Segunda Guerra Mundial que las élites blancas venezolanas han comenzado a reconocer abiertamente "la parte negra de su ancestro" (8-9). De modo que, sólo al superar conceptos biologistas/racistas ha sido posible empezar a aprehender con toda su complejidad el lugar que ocupa lo afro dentro de la identidad nacional de Venezuela y a darse cuenta de que "La música, la vestimenta, la lengua, la comida, las herramientas, los cultos religiosos, el folklore y las instituciones políticas y económicas de los venezolanos se caracterizan por las contribuciones de los tres grupos raciales" (Wright 8-9; traducción mía; lo subrayado es mío).

Encontrar y afirmar el lugar justo de lo afro en los esquemas nacionales han sido precisamente el punto de partida de mi lectura de Viajando por pueblos costeños. La novedad del texto de Martillo radica en el hecho de sugerir que lo afro ha dejado de caracterizarse como una alteridad absoluta. Este encuentro de culturas y vivencias diversas fundamentado en la tolerancia, el respeto y la aceptación implica importantes modificaciones a ciertas maneras tradicionales de definir lo que constituye lo afro tanto en el Ecuador como en el resto de las Américas. Bastante sugerente es la observación de Zapata Olivella: "América se negreó con los africanos, no por su piel negra, sino por su rebeldía, sus luchas antiesclavistas, su unión con el indio para combatir al opresor, por sus tambores, por su músculo, por su inquebrantable optimismo de pueblo vencedor" (330).

Por consiguiente, hay que insistir en la necesidad de no reducir lo afro a algún color llamado negro ya que tales distinciones siempre han sido arbitrarias y peligrosamente ambiguas. Peter Wade ha puntualizado al respecto que “'lo negro' no es una categoría patente, sino que se presta a la negociación y a la manipulación.... Aunque está claro que señales físicas juegan un papel para 'fijar' la identidad, es imprescindible reconocer que estas señales físicas están de por sí construidas históricamente" (343; traducción mía)). A su vez, Crawford Young ha destacado la misma subjetividad y fluidez de conceptos al estudiar la etnicidad como un fenómeno esencialmente subjetivo: "la definición de atributos comunes de etnicidad puede incluir la lengua, el territorio, el sector polí- 
tico, o valores culturales comunes o símbolos. En cualquier caso, estos factores pueden ser importantes rasgos definitorios en diferentes medidas, o uno o más de ellos pueden estar ausentes" (48-9; traducción mía).

$\mathrm{Al}$ rechazar categorías basadas en el color de la piel por una parte, $y$ al reconocer las diversas posibilidades de interpretación en lo que respecta a las etnias por otra parte, uno comienza a captar la naturaleza proteica e interrelacional de diferentes grupos humanos que coexisten y que mantienen un contacto que puede ser fugaz como puede ser continuo. Esta última acotación es fundamental puesto que pide que se abandone una rígidez conceptual que tradicionalmente ha construido un pensamiento binario y falsamente estático que, en efecto, ha servido para negar la pluralidad dinámica del mestizaje. De nuevo, Crawford Young es pertinente al análisis. Al comentar el punto de vista antropológico tradicional acerca de la "tribu" y el supuesto proceso de "detribalization" debido a las migraciones hacia centros urbanos, Young ha anotado que si bien es cierto que la identificación con la tribu natal desde la ciudad se transforma y asimila nuevas experiencias y vivencias, no deja de existir, sin embargo, como un elemento medular de la identidad de los grupos migratorios. Concretamente, ha explicado:

Si "tribu" se refería a la unidad rural autosuficiente, era lógico pensar que aquélos que migraron de su propia tierra a una ciudad nueva, políglota, ipso facto se habían sacado a sí mismos del sistema "tribal," y así se habían "destribalizado."... Sin embargo, nada podría estar más lejos de la verdad. Las identidades se cambian en circunstancias urbanas, en función a los requisitos sociales marcadamente diferentes. En el fondo, la metáfora de la "destribalización" confunde estructura con identidad. Se quita al individuo del patrón total de relaciones sociales del campo, por lo menos parcialmente. Pero, la identidad es un asunto muy distinto. La autodefinición étnica requiere la reconceptualización para satisfacer las necesidades de la vida urbana — un proceso facilitado por la naturaleza entrelazada y múltiple del fenómeno de la identidad.... (37; traducción mía)

La apertura conceptual que resulta de los planteamientos de Young y de Wade ayuda a valorar lo afroecuatoriano como un fenómeno cultural más que racial en una sociedad mestiza donde distinciones de sangres carecen de sentido. Al aplicar la explicación que Young hace sobre la identidad de la tribu desplazada a la diáspora afro en general, aquellos esfuerzos por confinar lo afroecuatoriano principalmente a una sola provincia (Esmeraldas) o a un solo color de piel pierden vigencia. Paralelamente, las distancias espaciales y temporales que separan al Ecuador de Africa propiamente no deben seguir empleándose como motivos de deslegitimación de lo afro en el Ecuador. En otras palabras, las mezclas múltiples y las adapta- 
ciones diversas que han ocurrido desde el siglo XVI no deben considerarse una negación absoluta de los orígenes por más remotos que éstos parezcan. De hecho, Norman Whitten ya ha puntualizado:

Gestos del cuerpo, modos de llevar a los niños... y algunas cargas..., modos de esquivar la vista ajena

... junto con modos musicales, el papel de ciertos santos como San Antonio, y algunos temas del folklore son, tal vez, tan africanos como en cualquier otra parte del Nuevo Mundo. Pero no es una cultura africana que parece perdurar; más bien, tenemos lo que he preferido llamar informalmente "la cultura afro-hispánica." No importa lo que sea la configuración de eventos y de posiciones sociales, ni tampoco las relaciones particulares entre aparatos culturales (materiales, sociales y mentales), el sentido general que se tiene es de una sociedad vital con raíces fuertes en Africa y Europa, pero del Mundo Nuevo. (Black Frontiersmen. A South American Case 13; traducción mía)

Indudablemente, lo que hace difícil aprehender ampliamente lo afro en el contexto cultural de la Costa ecuatoriana es la tendencia de depender de referentes demasiado superficiales e inmediatos. El mismo problema ha marcado la suerte de lo afro en otros países de América. En un sentido general, Sidney Mintz ha constatado:

Las manifestaciones superficiales de los orígenes africanos... han sido usadas con demasiada frecuencia como las únicas medidas del grado de "africanía" o como suficiente evidencia por sí mismas, soslayando rasgos más profundos y fundamentales que estaban necesariamente presentes. En realidad, manifestaciones superficiales (tales como la probable presencia de palabras de raíz africana) pudieran o no ser los más africanos de los rasgos sobrevivientes; su ausencia puede distraer a los estudiosos de la presencia de materiales más fundamentales, pero más sutiles, de origen africano. ("Africa en América Latina: una reflexión desprevenida," en Moreno Fraginals, ed., 389)

En el caso concreto de Colombia, Wade confirma la tesis de Mintz al puntualizar que "los negros colombianos están relativamente distanciados de su herencia cultural africana... Esto no quiere decir que no haya muchos aspectos culturales en Colombia que vienen de Africa: el estilo musical de mucho de la música, cuando no la forma y el contenido, es muy africano..." (267; traducción mía). Luego, Wade continúa su análisis afirmando: "Está claro que los africanos importados a Colombia han ejercido un gran impacto sobre la evolución de la cultura colombiana, especialmente a través de los dos litorales, pero también en otras partes.... De acuerdo a ideologías nacionalistas del mestizaje, entendido como blanqueamiento, las contribuciones africanas a la cultura colombiana han sido, por lo general, ignoradas" (267-68; traducción mía).

La evidente coincidencia de inquietudes e ideas que comparto con los investigadores ya citados demuestra una vez más que lo afro y la cultura costeña en el Ecuador apuntan hacia una problemática 
más global que a una estrictamente nacional. Además, el acercamiento cultural y emocional a Esmeraldas que Martillo hace en Viajando por pueblos costeños trasciende dicho texto. En efecto, el lector se encuentra inmerso en una confluencia de tiempos y espacios donde lo nacional es lo continental y donde un reportaje de viajes termina borrando las fronteras artificiales que tantas veces han obstaculizado una aprehensión amplia de la vida, por lo menos en lo que se refiere a las relaciones entre razas y etnias diferentes. Dicho de una manera más precisa, mi lectura de Martillo parece remontarse a las ideas de Miguel Acosta Saignes-ideas de otra época y de otro país-quien

creía que... un proceso largo de mestizaje racial y cultural, en realidad, había africanizado a blancos y a pardos en vez de haber hispanizado a los negros. Mientras que estudios anteriores acerca de la población de Venezuela... resaltaron los aspectos mestizos de la población, Acosta Saignes demostró la necesidad de tomar en cuenta las raíces africanas de la nación. Como dijo una vez, "La historia del proceso de la cultura venezolana es, entonces, la historia de la indigenización y la africanización del español en nuestras tierras." (Wright 119-20; traducción mía).

Esta misma africanización de lo nacional está implícita en Martillo quien describe su viaje a Esmeraldas como un retorno a los orígenes. Su entusiasmo por lo afro invita a poner en tela de juicio toda una tradición racista en la cual "los ras- gos de carácter estereotípicamente identificados con la sangre negra en la cultura nacional son casi todos perjudiciales. Los no-negros dicen que los negros están dispuestos a hacer el esfuerzo necesario sólo para sobrevivir...." (Stutzman, "El Mestizaje. An All-Inclusive Ideology of Exclusion," en Whitten, ed., Cultural Transformations and Ethnicity in Modern Ecuador, 79; traducción mía). La actitud de Martillo, en cambio, parece ubicarse dentro del pensamiento afrocéntrico que enseña que "la amplia distribución y diversidad de los pueblos de origen africano-y su inmensa contribución cultural y estética a la riqueza de las tradiciones hemisféricas-constituyen el producto final de largos siglos de cambio, durante los cuales los afroamericanos no fueron simplemente el sujeto pasivo e inconsciente de procesos externos sino, a menudo, y por el contrario, agentes activos de las propias transformaciones" (Mintz, en Moreno Fraginals, 392).

Lamentablemente, las condiciones necesarias para que el negro ecuatoriano y lo afroecuatoriano se consideren esenciales en la formulación conceptual de la identidad nacional, y sobre todo, de la identidad costeña, todavía no existen. Actitudes racistas siguen dominando el panorama nacional y se vislumbran desde los inicios mismos de la nación ecuatoriana del siglo XIX. En la campaña presidencial de 1835, Vicente Rocafuerte atacó al régimen militar del General Juan José Flores por haberse servido de negros y mulatos nacidos en Colombia y Venezuela al 
organizar las fuerzas armadas del país. El investigador, Leslie Rout, ha comentado que Rocafuerte "sostuvo que la presencia de estas tropas negras del exterior era una amenaza para la seguridad nacional. El punto de vista de Rocafuerte ganó fuerza debido a las actividades controvertibles del Coronel José Otamendi, un negro que mató e hirió a varios blancos de clase alta en ... Riobamba porque ellos supuestamente le habían faltado el respeto a su esposa" (227; traducción mía).

Entrados ya en el siglo XX, el miedo expresado por Rocafuerte para tratar a los negros se había cambiado a un desprecio típico del pensamiento sociológico racista del siglo XIX. El mismo Rout ha anotado que "los intelectuales ecuatorianos con frecuencia han manifestado una actitud de indiferencia o desdén para con los negros y los mulatos. Entre los más conspicuos es Alfredo Espinosa Tamayo, quien en 1918 descartó a los afroecuatorianos como miembros de 'una raza servil, creada en la esclavitud,' y anunció su oposición inalterable a la mezcla de razas puesto que el africano era conocido por haber sido maldecido con 'cualidades mentales inferiores"” (232; traducción mía).

No estará de más recordar que "A lo largo de todos los eventos históricos que dieron forma y contenido a la nacionalidad ecuatoriana, si aceptamos lo escrito en los textos escolares, la población de esclavos africanos jugó un papel mínimo. Se dice que el mestizaje asumió, durante ciertos períodos y en ciertos lugares, un componente negro. Pero no se mencionan frutos positivos de esta mezcla" (Stutzman, en Whitten, ed., Cultural Transformations and Ethnicity in Modern Ecuador, 63; traducción mía). No ha de extrañar, entonces, que en el Ecuador "La gente clasificada nacionalmente como no-negra tiene más acceso a los recursos de la economía política que la gente clasificada como negra" (Whitten, Black Frontiersmen: A South American Case 16; traducción mía). Por consiguiente, a pesar de toda la atención que se ha dado en los últimos años a la plurinacionalidad ecuatoriana, la situación actual del negro en el país sigue siendo patética. Antonio Preciado no ha dejado lugar a dudas en cuanto a estas condiciones:

La última rueda del coche sigue siendo el negro, aún y paradójicamente en su provincia natal. En los principales puestos burocráticos y del sector privado no encuentras gente negra, existen poquísimas excepciones. Hay un etnocentrismo a nivel nacional, pretendidamente blanco, excluyente y peyorativo con los negros. Tanto así que el negro se acostumbró, casi, a pensar en negativo, a peyorarse él mismo, se lo hizo históricamente un ser inferior, y es necesario superar esa imposición histórica, pero es fácil decirlo cuando no se está inmerso en esa realidad apabullante que vive el negro. El racismo persiste más allá de la pátina de aparente igualdad; si escarbas un poquito lo encuentras muy latente, muy vivo y doloroso. (En entrevista con Jorge Martillo, "El poeta les muestra sus raíces," 11)

Este rechazo con toda su historia en el Ecuador ayuda a explicar por qué encuentro en Martillo (y en Velasco Mac- 
Kenzie con su novela, Tambores para una canción perdida) una nueva posibilidad de revalorar lo afroecuatoriano. No es decir que no hubiera hasta ahora un interés en lo afro. Pero, la influencia del mestizaje como esencia de la nacionalidad ha impedido que algunos de los intelectuales más progresistas del país asimilaran algunos aspectos de lo afro como algo propio. Se ha observado que "La noción de que la gente desea y está dispuesta a cambiar la etnicidad por la nacionalidad, a aceptar las metas de la cultura nacional y hacerse blanca, rara vez ha sido cuestionada en el Ecuador o en los Andes, en las Américas o en el mundo" (Stutzman, en Whitten, ed., Cultural Transformations and Ethnicity in Modern Ecuador, 49; traducción mía).

Ya hice referencia a cierta ambivalencia de actitudes y conceptos sobre lo afroecuatoriano en el pensamiento de Aguilera Malta, por ejemplo. Mientras que su solidaridad para con los negros ha sido incuestionable, su insistencia en describirlos como una "minoría, que vive casi aislada" podría haberse prestado a distorsiones que otros habrían terminado empleando para detener una verdadera campaña contra el racismo sufrido por los negros y, al mismo tiempo, para negar las contribuciones no aisladas de lo afro en el vivir nacional. En efecto, al retomar esa inquietud, he argumentado a través de este capítulo que relegar lo afro a los márgenes de lo ecuatoriano repercute de una manera muy especial en la Costa del país. Esmeraldas es la Costa, y de acuerdo con mi interpretación de Viajando por pueblos coste$\tilde{n} o s$, hay que trascender aquellas fronteras que todavía aíslan Esmeraldas del resto del litoral. No con poca razón ha observado Whitten: "El que participa en la cultura afro-hispánica es, primero, un 'costeño,' y luego, un 'moreno"' (Black Frontiersmen: A South American Case 177; traducción mía).

De las diversas ideas desprendidas del texto de Martillo, quisiera insistir en la necesidad de reconocer que las influencias culturales vienen y van. Es decir, un pueblo es simultáneamente un receptor y un generador de vivencias. Así es el caso de Esmeraldas en relación con el resto del país. Laura Hidalgo ha anotado que "Esmeraldas no es la misma provincia de principios de siglo.... El medio tradicional se transforma. La radio, la televisión, las carreteras abren su mundo a otros espacios, a otros problemas. Guayaquil, Quito, Manabí reciben a centenares de negros que emigran de Esmeraldas desgarrando lazos con su tradición" (Décimas esmeraldeñas 177). Pero como he puntualizado varias veces ya, la separación del espacio natal no implica una aniquilación de la cultura originaria, sino una transformación. Además, es de una importancia vital recordar que los grupos migratorios también transforman sus nuevos escenarios. Ya no hay enclaves totalmente aislados en los grandes centros urbanos como Guayaquil. Por eso, Martillo ha podido encontrar lo afro en algunos barrios populares no necesariamente negros de esa ciudad. De una manera parecida, Wade ha comentado respecto a la Costa de Colombia: "El sincretismo que produjo la música de la Costa es complejo, pero la influen- 
cia negra es patente $y$, más importante aún, entre los mismos colombianos, en general, se la ve como un rasgo primordial de la cultura costeña" (90; traducción mía).

Sería un grave error, sin embargo, limitar las influencias de lo afro a la música. No se trata aquí de validar viejos estereotipos para quedarse en la superficie. Pero, para que haya una verdadera profundización, se tendrán que emplear nuevos instrumentos analíticos y de investigación al mismo tiempo que el país empiece a aceptar lo afroecuatoriano como algo realmente suyo. Y, dentro de ese proceso, es lógico que los costeños y, sobre todo los guayaquileños, asuman un papel decisivo en la elaboración de nuevos modelos de pensar y de convivir. Whitten ya ha observado que en lo que se refiere a Guayaquil, "Su fuerza nacional no surge por haber preservado la jerarquía andina, sino por haberla desafiado. Guayaquil, como la base metropolitana del poder de la Costa, no sirve solamente como un contrapunto ecológicoeconómico de Quito, sino como un desafío al conservadurismo y al catolicismo, también" (Cultural Transformations and Ethnicity in Modern Ecuador 4; traducción mía). En efecto, la obra de Martillo-escritor guayaquileño-parece apuntar hacia ese fin de revisión.

\section{Conclusión}

Al tomar en cuenta la última cita de Whitten, conviene recordar que las rivalidades y los conflictos entre la Costa y la Sierra a través de toda la historia del Ecua- dor son archiconocidos, y aunque muchos pensadores se han esforzado por explicarlos desde diversos puntos de vista (la geografía, la economía y la política, por ejemplo), la presencia afroecuatoriana en la Costa todavía no se ha estudiado como una fuerza cultural positiva con aportes importantes dentro de la diferenciación de las dos regiones. Un ejemplo reciente de este fenómeno se vislumbra cuando Milton Alava Ormaza comenta un ensayo que Enrique Ayala escribió sobre la plurinacionalidad. Mientras que la escisión tradicional entre la Costa y la Sierra vuelve a sentirse, en el análisis se sigue excluyendo lo afro como parte de las explicaciones. Según el comentarista,

mi enfoque del problema no puede ser ajeno a mi costeñidad.... [La] Costa ecuatoriana no surgió a la vida republicana con una población indígena, pues allí se operó eso que los antropólogos llaman aculturación y que en esta región tuvo la característica de ser total. El tipo humano que en la literatura se conoce como "cholo," es en buena parte resultado de este proceso. En consecuencia,... nosotros los costeños no concebimos ni sentimos el problema indígena como, con toda razón, se lo plantean los serranos. (En Ayala y de la Cruz, Pueblos indios, estado y derecho, 50)

Aunque el comentario citado me parece acertado al reconocer que el costeño no se identifica con lo indígena a la manera serrana, hace falta complementar tal aseveración con una afirmación de "costeñidad" que sí apunta hacia lo afro ya que 
las afinidades caribeñas del costeño pertenecen a un circuito cultural que une la Costa ecuatoriana con el Caribe y está ampliamente matizado por lo esmeraldeño.

Volviendo de nuevo a Viajando por pueblos costeños, en lo que respecta al concepto de la identidad nacional, el espíritu de asimilación de lo afro encontrado en Martillo es sumamente sugerente. En general, mientras que el Ecuador como concepto nacional visto desde la Sierra se ha fundamentado muchas veces en la aceptación de la herencia indomestiza (por lo menos en teoría), los costeños nunca se han sentido completamente cómodos con tales perspectivas étnico-raciales. Debido a una larga tradición de racismo respecto a lo afro ya tratada en este capítulo (y en los anteriores), el costeño no ha podido expresar su oposición a aquellos conceptos de nacionalidad prevalecientes, y que siguen siendo más bien propios de la zona andina, en términos de una exaltación de herencias culturales que podrían trazarse, directa o indirectamente, desde Africa. En parte, la ignorancia ha impedido tal acercamiento y, por lo tanto, urge que se realicen múltiples estudios en diversos campos investigativos. Sólo así se podrá descubrir la verdadera diversidad que constituye la Costa por un lado, y la nación ecuatoriana por otro.

\section{Notas}

1 A pesar del reconocimiento general que hay en el país acerca de la importante población de gente negra del Valle del Chota en la Sierra, Esmeraldas sigue siendo la provincia definitoria cuando alguien se refiere a los afroecuatorianos.

2 La referencia al cambio en la inmigración de negros trata de la política del Presidente García 


\section{Capitulo V \\ Las contradicciones ineludibles del "no-racismo" ecuatoriano: A propósito de Juyungo como artefacto de la diáspora afroamericana}

Moreno quien rechazó la entrada al país de los negros de los Estados Unidos durante la época de 1862-1869.

\begin{abstract}
"The problem of the Twentieth Century is the problem of the color-line." (W.E.B. DuBois, The Souls of Black Folk)

\section{Introducción: Lo afroecuatoriano en un contexto transnacional}

Aunque el epígrafe fue escrito en 1903, y se refería primordialmente a la situación de los Estados Unidos de aquel entonces, la visión de DuBois no fue solamente profética, según su contexto, sino que terminó trascendiendo fronteras geográficas y temporales. Con el advenimiento vertiginoso del siglo XXI, la vigencia del problema racial sigue afectando profundamente las relaciones humanas en todo el mundo, y más concretamente, en todo el continente americano. A través de todo el siglo XX (cuando no antes), ha habido mucha gente que ha pretendido limitar la cuestión de las razas y sus matices racistas a la situación particular de los Estados Unidos. En cuanto a América Latina, el mestizaje supuestamente ha creado una tolerancia y aceptación general de las diversas razas. Pese a esa retórica vasconceliana, una mirada detenida revela un sin- 
número de fisuras en aquella identidad latinoamericana tradicionalmente arraigada en dicho mestizaje. Es así que se ha observado en un reportaje acerca de "The Black Americas (1492-1992)," que fue preparado como aporte al análisis general del Quincentenario de las Américas:

A pesar de las letanías ampliamente difundidas sobre "la democracia racial" sin color de América Latina, la discriminación obvia continúa avasallando a los descendientes de diez millones de esclavos africanos a quienes se los trajo a trabajar en las plantaciones y minas del Nuevo Mundo. Tal discriminación se agrava aún más debido a una negación casi universal de la herencia e identidad negras, algo que, en efecto, ha hecho invisibles a los negros. (NACLA 15; traducción mía)

La tendencia de eliminar lo afro de toda discusión seria y comprehensiva acerca de la nacionalidad mestiza ecuatoriana es la consecuencia de lo que se podría categorizar como una tradición racista que se vislumbra, de una manera u otra, en todos los lugares de la diáspora africana. Richard Jackson ha puntualizado que "el concepto del [...] mestizaje, un proceso que, si bien se define libremente como una fusión étnica y cultural, se lo comprende a menudo como la violación espiritual y cultural de la gente negra" (The Black Image in Latin American Literature 1 ; traducción mía). En un sentido más general, dentro de la construcción de un estado nacional, el mestizaje sirvió también de fuente aglutinadora $y$, por lo tanto, to- do intento de resaltar diferencias culturales, raciales y étnicas se vio como una amenaza al orden social y a la estabilidad. No sorprende que se haya puntualizado que

Se llegó a considerar subversiva la diversidad étnica, racial y cultural, un desafío a la nación oficial definida según su supuesta homogeneidad: un solo pueblo mestizo que habla una sola lengua y cree en un solo Dios. La Izquierda latinoamericana, una creación del nacionalismo y del anti-imperialismo, ha hecho muy poco para desafiar este principio básico de la identidad. En diferentes medidas, la lucha de liberación multifacética de los negros, vigente desde 1502, fue absorbida por la lucha de "clases," el racismo blanco, anteriormente una característica de la sociedad abiertamente reconocida, se hizo un tema tabú, negado junto con la gente que sufría sus efectos. (NACLA 15; traducción mía)

Respecto al Ecuador, Nelson Estupiñán Bass parece haber captado gran parte de los matices del problema racial frente al mestizaje y los conceptos de nacionalidad al escribir en el número inaugural del $\mathrm{Me}$ ridiano Negro (1980), "una revista que constituyera la voz de la negritud ecuatoriana":

Toda vez que por el Ecuador pasa un meridiano de la negritud universal, hecho innegable por la existencia de densas y crecientes comunidades negras en varias provincias del país, consideramos conveniente relevar nuestro pigmento, mediante la publicación de este órgano que hoy 
sale a la luz pública, seguro de aglutinar todas las voces negras de la Patria, y de convertirse por lo tanto, en el auténtico pregón de este gran segmento, marginado y aplastado, de nuestra nacionalidad, hasta hoy sin voz ni voto en las grandes decisiones nacionales. No preconizamos la odiosidad racial. Recalcamos, como suprema norma de convivencia, la fraternidad universal ... (Este largo camino 202)

Mientras que el mensaje de reivindicación racial presentado por Estupiñán rompe con la tradición homogeneizadora del mestizaje oficial al destacar la exclusión sistemática padecida por los negros ecuatorianos, él insiste en expresarse en términos nacionales y, consecuentemente, su conciencia racial se ha de entender más bien como un intento de ampliar el concepto del mestizaje en vez de negarlo. Es de notar que además de buscar una nacionalidad más amplia que la tradicional, Estupiñán también coloca la cuestión racial en un contexto doblemente universal. Por una parte, se refiere al negro como miembro integral de todo el país; por otra parte, él vincula al afroecuatoriano a una comunidad transnacional: "por nuestra ubicación social y nuestro ancestro expresamos sistemáticamente nuestra solidaridad con los hermanos de otras naciones_-jsus luchas son nuestras!- -donde las clases milenariamente dominantes mantienen aún al Hombre Negro bajo las horrendas condiciones de sojuzgamiento" (203). Consciente o inconscientemente, con este doble discurso de ser negro y ecuatoriano (o ecuatoriano y negro), Estupiñán inser- ta al Ecuador dentro de la diáspora afroamericana e invita a los demás a reformular sus conceptos sobre la nacionalidad, el mestizaje y la negritud.

Las implicaciones del citado texto de Estupiñán van más allá de la cuestión puramente afroecuatoriana, sin embargo. Las inquietudes expresadas por Estupiñán, junto a todos los intereses políticos e ideológicos oficiales del país que siguen tergiversando y deslegitimando los esfuerzos por crear una nueva nacionalidad caracterizada por un pluralismo y heterogeneidad visibles y abiertamente desafiantes a toda fuerza canónica o hegemónica, apuntan a un movimiento global y, más concretamente, latinoamericano. A nivel continental, muchos han denunciado el contenido represivo de los discursos del mestizaje tradicional al relacionar éste a una nueva forma de "una ideología monolítica en la que el problema del Otro marginalizado puede resolverse mediante una mera integración dentro de prácticas dominantes de lo cultural, lo político, lo económico y lo discursivo, y no por un deseo de escuchar la 'voz' del Otro como verdaderamente oposicional y capaz de modificar conceptos hegemónicos de la nación y estrategias de la construcción nacional" (Chanady xvi; traducción mía).

En efecto, una de las contribuciones más rescatables de los defensores de lo afro en América Latina trasciende los esquemas insulares y pertenece a un movimiento reivindicativo propio de diversos grupos marginados de toda América Latina (especialmente ciertas comunidades 
indígenas y ciertos grupos de mujeres) que han difundido la noción de una cultura latinoamericana híbrida y eternamente abierta a modificaciones. A diferencia de la fusión esencialista y, por lo tanto, estática del mestizaje tradicional limitado sobre todo a sus componentes blancos e indígenas, se ha propuesto una identidad cultural vista como un "crisol de influencias heterogéneas que cambia continuamente" (Chanady xxxv; traducción mía). Por consiguiente, "Para un número creciente de intelectuales, no existe una cultura latinoamericana 'auténtica,' ni siquiera una síntesis mestiza" (Chanady xxxvi; traducción mía). Es así que el crítico peruano, Julio Ortega, ha constatado al comentar la situación peruana: "Creer ... que la nación andina deberá marchar hacia un mestizaje nivelador es iluso y peligroso: una suerte de 'destino manifiesto' que no podemos sino rechazar" (215).

La insistencia en una América Latina híbrida, producida dentro de un proceso constante de contactos sociales que a su vez genera transformaciones evolutivas, es propia del pensamiento poscolonial de fines del siglo XX. Homi Bhabha ha puntualizado:

La perspectiva poscolonial nos obliga a repensar las limitaciones profundas de un consensual y colusorio sentido "liberal" de comunidad cultural. [Esta perspectiva insiste] que la identidad cultural y política se construye mediante un proceso de alteridad. Cuestiones de raza y diferencia cultural se sobreponen a temas de sexualidad y género y sobredeterminan alianzas sociales de clase y del socialismo demo- crático. El tiempo para "asimilar" minorías a nociones totalizadoras y orgánicas de valor cultural se ha acabado dramáticamente. (The Location of Culture 175; traducción mía)

No será una exageración sugerir que el propósito expresado por Estupiñán en aquel primer número de Meridiano Negro, ya citado, ha de leerse como un reflejo de la medida en que algunos sectores del Ecuador están contribuyendo al discurso poscolonial (por lo menos, según Bhabha lo define). Pero, aunque se ha prestado bastante atención a las luchas indígenas dedicadas a solidificar un reconocimiento general del Ecuador como un país plurinacional, pocos han visto en los grupos afroecuatorianos una fuerza medular dentro del debate poscolonial sobre la nacionalidad ecuatoriana. Huelga recordar que el poner de relieve lo afro como elemento nuclear de las diferencias raciales al tratar la identidad cultural del país data desde los años cuarenta con la publicación de Juyungo (1943) de Adalberto Ortiz. Este texto, más que cualquier otro que se haya escrito en el Ecuador, recoge la complejidad y la conflictividad inherentes al tema afro y el lugar que éste ha de ocupar en la construcción teórica de la nacionalidad ecuatoriana.

\section{Juyungo como testimonio y artefacto de la diáspora}

Aparte de los elementos claramente afros de Juyungo (e.g., referencias a las costumbres, tradiciones y folklore de Esmeraldas), lo que más interesa aquí son las 
tensiones internas (textuales) y externas (contextuales) que problematizan el tema racial en el Ecuador y que establecen la novela de Ortiz como un artefacto sociocultural fundamental dentro del proceso evolutivo e híbrido que sigue siendo la diáspora tanto en el Ecuador como en el resto del mundo. ${ }^{1}$ De hecho, la misma actitud ambivalente de Ortiz respecto a lo afro es testimonio de lo difícil que ha sido integrar la diáspora y conceptos de nacionalidad. Es así que su condición de mulato y su formación intelectual realizada durante una época profundamente influida tanto por el realismo social como por el mestizaje tradicional, revelan contradicciones que todavía no se han resuelto. En una entrevista con Carlos Calderón Chico, publicada en 1991, Ortiz constató que "no soy un negro ciento por ciento; yo soy un mestizo y me he criado en un ambiente de blancos. Por un lado, tengo una influencia emocional de la cultura negrista, de los sentimientos negros ...; [pero] la formación mía y de muchos hispanomericanos, aunque lo quieran negar, es hispánica-española, la formación era netamente hispánica" (128). Tal aseveración sobre lo esencial de la hispanidad podría entenderse como una negación de lo afro, especialmente al reducir éste al plano puramente emocional. Además, la insistencia en su condición de mestizo en vez de mulato no parece ser un mero giro semántico ya que recuerda la observación del antropólogo, Whitten: "El error usual de los latinoamericanos es asignar demasiado peso al concepto del mestizaje, como si todos los 'problemas' de la negritud desaparecieran con la creciente mezcla racial de las regiones" (Pioneros negros 232).

En la misma entrevista con Calderón Chico citada arriba, Ortiz continuó hundiéndose en contradicciones al afirmar: "Uno pierde mucha energía pensando en la raza, en una raza que, perseguida o marginada, va creando el complejo: pensar en negro, pensar en indio o pensar en judío. Aunque eso de pensar como un grupo racial marginado o perseguido, y perder mucha energía y mucho tiempo en eso, a la larga se convierte en un estímulo de superación" (127). La oscilación entre una supuesta futilidad, por una parte, y la posibilidad de una "superación" colectiva al "pensar en negro," por otra parte, parece ser producto de un conflicto interior en el cual Ortiz quería ser aceptado como un miembro más de una sociedad ecuatoriana, utópicamente construida según el concepto decimonónico de "la nación homogénea," mientras que él seguía sintiendo la necesidad de cultivar una herencia distinta que fácilmente podría tergiversarse como un comportamiento separatista en contra del conjunto nacional. La tensión entre estos dos extremos también fue identificada como un rasgo central de $J u-$ yungo cuando Richard Jackson escribió:

El autor nunca parece estar seguro de cómo tratar la negritud de Lastre en relación a su propósito más amplio. La fuerte imagen negra que le da a Lastre es tan fuerte que, de hecho, la evolución psicológica de la raza a la clase que se supone que estamos presenciando en la novela nunca 
se materializa. Lastre nunca pone a un lado su memoria étnica; él de ninguna manera la relega a una posición secundaria. (Black Writers in Latin America 125; traducción mía)

La ambivalencia que se patentiza, tanto en las declaraciones de Ortiz como en su Juyungo, obliga que se vuelva a la época en que toda su obra se gestó, para así, descubrir algunas circunstancias e influencias que ayudan a explicar las actitudes contradictorias de Ortiz. Primero hay que reconocer que, como escritor e intelectual, Ortiz se había formado dentro del realismo social ecuatoriano de los años treinta, una época intensamente progresista en la cual la producción literaria clamaba por la justicia social y por un estado nacional auténticamente representativo de las mayorías del país. Según Fernando Tinajero, los principales escritores de la época expresaron la situación de una clase media emergente que "indaga los trasfondos de una cultura popular hasta entonces negada; crea los códigos necesarios para consolidarla en el mismo proceso de su comunicación ...; funda, en una palabra, la posibilidad antes impensable de una cultura nacional-popular" (De la evasión al desencanto 53-4). Por su parte, Patricia Varas ha constatado que en lo que respectaba a la narrativa de los años treinta, "Las nuevas técnicas fueron adoptadas en función de un plan de integración nacional que adquirió una voz narrativa con claro contenido popular ..." (Narrativa y cultura nacional69-70).

De manera que Ortiz se formó den- tro de un ambiente profundamente marcado por la reivindicación social y por un fuerte deseo de crear una nación a partir de una nueva consolidación de los diversos grupos campesinos y urbanos que hasta entonces habían sido marginados de los centros del poder. No estará de más señalar aquí que los principales exponentes intelectuales del proyecto nacional-popular de la época estuvieron vinculados, directa o indirectamente, a los Partidos Socialista y Comunista y, por lo tanto, sus propuestas apuntaban a una nueva conciencia de clase junto a una transformación radical de las bases económicas del país. Tal ha sido el caso de Joaquín Gallegos Lara, uno de los escritores y pensadores más destacados de la época. De hecho, Ortiz ha reconocido que Gallegos Lara "fue un gran hombre y en mi caso personal fue mi maestro" (Calderón Chico 113-14).

Es a partir de este reconocimiento que hace Ortiz sobre la influencia profunda que Gallegos Lara había ejercido sobre él que uno comienza a percatarse de los obstáculos que descarrilaban toda discusión acerca de la negritud ecuatoriana. La lucha de clases se consideraba un sine qua non y, por consiguiente, las cuestiones netamente raciales, étnicas, culturales y de género sexual se perdieron en los proyectos socioeconómicos de la época. En una reseña que Gallegos Lara había escrito sobre Juyungo en 1945, el mentor de Ortiz puntualizó: "Los negros sufren la civilización como trabajadores y como negros. Su liberación sólo la conseguirán con la de todos los hombres. La causa del trabajo en 
rebelión es la suya propia, sin racismo a la inversa" (Guerra Cáceres 55). En efecto, la liberación sólo sería posible mediante una lucha de "todos los hombres" ya que la insistencia en particularidades raciales, por ejemplo, sólo conduciría a la fragmentación de la consolidación de las masas obreras.

La posición articulada por Gallegos Lara no ha de sugerir una indiferencia o una ignorancia del sufrimiento del negro como negro, sin embargo. En la reseña sobre Juyungo, se denuncia la discriminación y sus efectos nocivos. Pero, curiosamente, dentro del breve análisis que hace Gallegos Lara sobre la situación del negro se vislumbra un pensamiento contradictorio. Según él había observado: "Es cierto que en Ecuador, en América Hispana ... el prejuicio discriminativo no domina ... ¡Pero, aunque sea en América Hispana, ser negro, es ser negro!” (Guerra Cáceres 57). La frase final de esta última declaración no tendría sentido si la discriminación en América Hispana, o en el Ecuador, fuera tan benigna como se sugería en la primera frase de lo citado. En cierta manera, la conclusión de "ser negro, es ser negro," contenía una tensión ideológica arraigada en una tendencia a reprimir lo que no se dejaba ocultar por completo. Es decir, la negación del racismo contra el negro y la búsqueda de un mestizaje armónico no coincidían con la verdadera situación que se vivía, y que se sigue viviendo, tanto en el Ecuador como en toda América.

El dilema con aceptar el análisis de Gallegos Lara radica en su tendencia a simplificar la interrelación dinámica e inseparable que existe entre la clase/la raza/el género sexual. Para él, el racismo era producto primordialmente del capitalismo y de una mentalidad burguesa que supuestamente no existirían en un futuro socialista, un futuro que se realizaría siempre que hubiera una lucha común de las masas trabajadoras, tanto las del campo como las de la ciudad. Volviendo de nuevo a la reseña de Juyungo, Gallegos Lara comentó la situación del mulato para concretar su mensaje revolucionario.

¿Cómo lograr que la unión sea no sólo física sino psíquica? ¿Cómo encontrar la síntesis de las tendencias contradictorias? Naturalmente sólo por la rebelión socialista y humanista contra la diferenciación racial de la sociedad burguesa, la personalidad blanca y la negra, dentro del mulato, alcanzarán a fundirse, integrando la individualidad única... Cuando al mulato no le enorgullezca ser más claro que los demás negros, ni le avergüence ser menos blanco que los demás blancos, habrá llegado a ser un sólo individuo, él mismo, eso que dicen nada más y nada menos que un hombre. (Guerra Cáceres 56)

El drama tan patente en la descripción que hace Gallegos Lara del mulato despierta dudas sobre su estrategia de cómo cultivar la deseada unificación puesto que parece minimizar los múltiples abismos que-quiéralo o no-separaban (y siguen separando) a las razas en el Ecuador y en América Latina. De hecho, las diferencias y las contradicciones raciales no quisieron desaparecer $y$, por consiguiente, el mismo Gallegos Lara terminó conclu- 
yendo sus comentarios sobre la discriminación con aquella frase contradictoria ya citada arriba de "ser negro, es ser negro."

Esta misma tensión creada por las diferencias que salen a flor de piel, pese a una deseada fusión, sugiere una vez más la influencia de Gallegos Lara en la concepción misma de Juyungo. Al recordar el proceso de escribir la novela, Ortiz ha constatado que "nadie había escrito sobre el negro; entonces, esa fue mi idea, y hablamos con Gallegos Lara, estuvimos pensando en eso, discutíamos constantemente, cambiábamos ideas" (Calderón Chico 120). ${ }^{2}$ De manera que el compromiso con una revolución socialista basada en la lucha de clases, tal como Gallegos Lara lo había enseñado en el Ecuador de los años treinta y cuarenta, contribuyó a confundir los términos del debate. Es decir, el temor de desarticular un movimiento obrero contra las injusticias de un estado opresivo hizo difícil cualquier esfuerzo por desarrollar plenamente reflexiones sobre la situación particular del afroecuatoriano. De hecho, el cuidado de no adoptar posiciones separatistas $y$, por lo tanto contrarrevolucionarias, sigue manifestándose cincuenta años después de la época en que Gallegos Lara defendió sus ideales. Ortiz ha comentado: "Yo no soy racista. El racismo bien canalizado conduce a tener conciencia de clase, por eso vemos en Estados Unidos el racismo, que hay ... muchachos negros que odian al blanco porque sí ..., hay que tener una conciencia de clase más social ..." (Calderón Chico 121-22).

No se pretende aquí negar la impor- tancia de una conciencia de clase al tratar de realizar verdaderas transformaciones en el Ecuador, o en cualquier país del mundo en que las mayorías se encuentran atrapadas en sistemas injustos y explotativos. Inclusive, desde el punto de vista predominante de muchos intelectuales progresistas de los años treinta en el Ecuador, por ejemplo, poner de relieve el factor exclusivo de "clase social" frente al problema socioeconómico del país tenía su lógica y razón de ser. Pero, a estas alturas, cualquier revisión efectiva que se espere hacer acerca del pensamiento de los años 30 y 40 y de sus textos más representativos-por lo menos, en lo que respecta al negro dentro del conjunto nacional ecuatorianoha de exigir criterios y lecturas que no solamente tomen en cuenta el horizonte de expectativas de la época (para usar la terminología de Hans Robert Jauss), sino que incorporen nuevos conceptos pertinentes que no circulaban mayormente en el pasado. ${ }^{3}$ Por lo tanto, un análisis actual de lo afroecuatoriano ha de complementar las formulaciones sociales de clase de Gallegos Lara y de Ortiz y, sobre todo, las que aparecen en Juyungo, con los componentes culturales y raciales tan patentes en las contradicciones inherentes a todo pensamiento excesivamente unidimensional. En efecto, aquella frase de Gallegos Lara ya citada ("ser negro, es ser negro") cobra su verdadero sentido al leerla como un reconocimiento de lo racial frente al contexto socioeconómico. Norman Whitten ha sido contundente al recordar:

La mayoría de la gente en las naciones de 
Ecuador y Colombia se considera de un ancestro racial mezclado. Sin embargo, se emplea el concepto de color a menudo para señalar la clase, el status o las posiciones de poder entre aquéllos que se consideran a sí mismos, y a los demás, racialmente mezclados. En tal clasificación, esta regla se impone: mientras más alta la posición de una persona frente a otra, más blanca se la considera. (Black Frontiersmen 176; traducción mía $)^{4}$

Desgraciadamente, el mero acto de reconocer lo racial como factor medular dentro de la composición nacional ecuatoriana no garantiza una aprehensión cabal de lo afroecuatoriano. Este es el caso de Justino Cornejo, importante antropólogo y folklorista del Ecuador, que escribió en 1973 un largo ensayo intitulado, "Los que tenemos de mandinga." Hacer referencia a este texto es pertinente aquí puesto que, junto a Gallegos Lara, Ortiz ha destacado a Cornejo como otro de sus mentores: "Justino Cornejo, gran maestro; parte de mi formación intelectual se la debo a Cornejo" (Calderón Chico 108).

A primera vista, "Los que tenemos de mandinga" parece marcar un paso adelante en cuanto a la concepción de la negritud ecuatoriana. Cornejo, que no era negro, insistió en celebrar lo afro y denunció continuamente aquellas actitudes de negación racial que durante la historia nacional habían convertido lo afro en un motivo de vergüenza y burla. Por lo tanto, después de asistir a una función del Ballet del Senegal en Guayaquil en 1973, Cornejo explicó:

El estado de ánimo que tuve al salir de la función en que guerra y magia, trabajo y religión se hallan mezclados en cuadros de rica plasticidad, me pareció propicio para dar comienzo a un proyecto acariciado desde hacía muchos años. Bajo ese clima debía yo traer mis recuerdos, sacudir mis pensamientos, volcar mis emociones, ordenar mis lecturas, en homenajeno importa que modesto-a la Raza Negra, en la no tan desdeñable porción de africanos que moran en tierras ecuatorianas, y como un llamamiento a los otroszambos y mulatos - al cumplimiento de una obligación sagrada. (5-6)

Sin embargo, el entusiasmo por lo afro, tan patente en las palabras de Cornejo, pertenece a la misma tradición de mestizaje que influyó a Gallegos Lara y a Ortiz. Según había afirmado Cornejo: "Población americana blanca no es población americana, como tampoco lo es la india. Nuestro signo diferencial con respecto a otros continentes es el mestizaje total: la fusión de las cuatro razas principales" (12). En efecto, mientras que la intención primordial del discurso de Gallegos Lara y Ortiz pretendió integrar lo afro en lo socioeconómico y, de esta manera, su mensaje del hombre universal ayudó a soslayar los efectos nocivos del racismo en el Ecuador, Cornejo trató de asumir una perspectiva más afín con la antropología cultural que, también, llevó al prologuista anónimo de "Los que tenemos de mandinga" a concluir que en el Ecuador "no existe conflicto racial alguno" (1).

$\mathrm{Ni}$ el entusiasmo por el folklore afroecuatoriano, ni la insistencia en un mestizaje armónico, sin embargo, pudo li- 
brar a Cornejo de muchas de las contradicciones y sutilezas del racismo. Con un contenido hondamente biologista y paternalista, "Los que tenemos de mandinga" se pierde en generalizaciones y estereotipos que distorsionan y trivializan las vivencias y experiencias del negro ecuatoriano. El pensador africano, Kwame Anthony Appiah, ha constatado que "una concepción de raza arraigada en lo biológico es, al mismo tiempo, peligrosa en la práctica y engañosa en la teoría" (176; traducción mía). Por consiguiente, es preocupante leer en el ensayo de Cornejo tales afirmaciones como:

- $[\ldots]$ tiene que haber habido plasma negro, lo que explica la sexualidad ardiente de Montalvo y su altanería incesante ...(87)

-De los negros, que unieron sus cromosomas a los de los blancos-hombres y mujeres-los costeños del Ecuador heredamos la altanería irreflexiva, que en ocasiones nos pierden. El serrano, en cambio, es generalmente reposado y frío. (36-7)

-El negro es insolente, además de gritón y temerario. No creo que sea malo ... Pero no perdona... Así es el negro, y mucho más, el mulato. (24)

Por más que Cornejo haya insistido que "en el Ecuador no padecemos de sarna racista" (8), y a pesar de sus investigaciones incansables sobre el folklore de Esmeraldas, el concepto esencialista que él había empleado al tratar al negro en "Los que tenemos de mandinga" revela una actitud etnocéntrica perjudicial para el afroecuatoriano. Así lo es, también, una tendencia paternalista que puede convertir inconscientemente el contenido de su ensayo en un instrumento racista, especialmente después de leer: "Malo, muy malo insolentar al negro, bestializarlo al negro, ...; pero siempre será sano y provechoso aleccionarlo sobre su historia y dignificarlo" (61). El mensaje de estas últimas palabras sólo puede conducir a un concepto del negro pasivo ya que supuestamente les compete a otros escribir su historia y darle un sentido de identidad. Esta imagen del negro que necesita que otros lo representen - o peor aún, que lo dignifiquen-no lo reconoce como un agente efectivo de acción y de lucha. Henry Louis Gates, Jr., en cambio, ha puesto de relieve la originalidad y creatividad del negro al comentar: "La capacidad del negro de crear esta rica poesía y de sacar de estos ritos una actitud compleja ante intentos de dominación, la cual se puede trascender dentro de y a través del lenguaje, es una señal de su originalidad, de su conciencia intensa de lo metafísico" (The Signifying Monkey 77; traducción mía). Y, finalmente, pese a sus buenas intenciones, el racismo tantas veces negado por muchos ecuatorianos a través de la historia parece incidir una vez más en el pensamiento de Cornejo quien había escrito: “iqué alma tan blanca la que lucen algunos morenos, capaces de acciones ejemplares aún en favor de los mismos que ayer gozaron torturándolos y aniquilándolos!” (74). La asociación que Cornejo hace entre el alma blanca y el negro heróico corrobora toda una tradición blanco-mestiza en que no se le concedió nunca al negro un espacio dig- 
no de respeto y emulación generales. ${ }^{5}$

Con el análisis que se ha propuesto en estas páginas sobre algunos de los comentarios de Gallegos Lara y de Cornejo acerca de lo afroecuatoriano, se espera haber sacado a la luz el contexto sociohistórico en el cual Ortiz había creado Juyungo, "tal vez la novela negra más ampliamente reconocida que haya salido de América Latina" (Jackson, Black Writers in Latin America, 122; traducción mía). La afirmación de Jackson sobre la importancia de Juyungo parece estar en contraposición con aquella noción de un Ecuador mestizo en que no hay racismo contra los negros. En un medio supuestamente caracterizado por tanta tolerancia y aceptación racial, resulta difícil comprender cómo Jackson podía haber llegado a la conclusión de que "La narración de Ortiz ... se considera un logro en la prosa que se puede comparar con la poesía de Nicolás Guillén: ambas obras constituyen comentarios clásicos sobre la experiencia negra de América Latina" (Jackson, Black Writers in Latin America, 122; traducción mía). En fin, la experiencia de ser negro, a la cual Jackson alude al referirse a Juyungo, surge de la tensión que existe entre un discurso oficial arraigado en una supuesta consolidación racial y una cultura afroecuatoriana que se niega a ser absorbida.

En cierta forma, el mestizaje nacional no ha podido apropiarse de lo afro puesto que éste constituye una visión del mundo propia de la diáspora africana $y$, por lo tanto, rebasa fronteras puramente nacionales. Juan Maiguashca ha constatado que "la visión del mundo es trans-sistémica" (186); por su parte, Norman Whitten ha señalado que los habitantes afroamericanos del litoral lluvioso del Pacífico "comparten una cultura supranacional en común" (Pioneros negros 206); y finalmente, Paul Gilroy ha sugerido que "el medir las similitudes y las diferencias entre las culturas negras sigue siendo una preocupación urgente. Esta respuesta depende crucialmente del concepto de la diáspora, ... Quiero afirmar que la diáspora todavía es indispensable para resaltar la dinámica política y étnica de la historia incompleta de los negros del mundo moderno" (80; traducción mía). Estos mismos conceptos de lo "trans-sistémico," "lo supranacional" y "la diáspora" están implícitos en aquella doble conciencia de ser ecuatoriano y negro que ya comenté al mencionar a Estupiñán Bass.

Por lo tanto, en vez de un fenómeno biologista tan patente en algunas de las ideas de Cornejo, y más que un proceso de síntesis racial manifiesto en ciertos comentarios de Gallegos Lara y Ortiz, la experiencia de ser negro ha de comprenderse en toda su diversidad y complejidad. De hecho, al mismo tiempo que Kwame Anthony Appiah ha sido contundente al rechazar la noción de que exista un solo "African worldview," él también ha enseñado que "los escritores africanos comparten tanto una situación sociohistórica como una perspectiva sociohistórica" (82; 
traducción mía). De ahí, se puede plantear que, en cuanto a los afroamericanos, lo sociohistórico con sus raíces en la trata, la esclavitud y la diáspora trasciende fronteras geopolíticas y coloca la experiencia de ser negro en el centro mismo de toda discusión postcolonial. Vale recordar a Néstor García Canclini quien ha observado:

Las naciones y las etnias siguen existiendo. El problema clave no parece ser el riesgo de que las arrase la globalización, sino entender cómo se reconstituyen las identidades étnicas, regionales y nacionales en procesos de hibridación intercultural. Si concebimos las naciones como escenarios multideterminados, donde diversos sistemas simbólicos se intersectan e interpenetran, la pregunta es qué tipos de literatura, cine y televisión pueden narrar la heterogeneidad y la coexistencia de varios códigos en un mismo grupo y hasta en un mismo sujeto. ("Narrar la multiculturalidad" 13)

En efecto, lo genial de Juyungo radica en el haber marcado un primer paso en lo que García Canclini ha identificado como la reconstrucción de una nacionalidad abiertamente intercultural. El haber insertado lo afro en el escenario nacional ecuatoriano abrió fisuras en el andamiaje blanco-mestizo y, aunque el problema racial todavía está lejos de resolverse en el Ecuador, Ortiz logró remover muchas de las tensiones y fuerzas sociales que siguen deteniendo la construcción de un estado unido a partir de sus múltiples particularidades. A diferencia de fórmulas tradicionales de asimilación como el mestizaje simplista a lo vasconceliano, Homi Bhabha ha puntualizado:

Discursos críticos poscoloniales requieren formas del pensamiento dialéctico que no nieguen o minimicen la otredad (la alteridad) que constituye el dominio simbólico de las identificaciones psíquicas y sociales. La desproporción de valores y prioridades culturales que el crítico poscolonial representa no puede ser acomodada dentro de teorías de relativismo o pluralismo cultural. (The Location of Culture 173; traducción mía)

En base a las reflexiones hechas hasta aquí (especialmente sobre el contexto sociohistórico en que se escribió Juyungo), es lógico que el mismo Ortiz no haya comprendido muchas de las implicaciones poscoloniales de su novela. Pero así como lo afro no se ha dejado absorber dentro de las diferentes sociedades americanas (incluyendo a la ecuatoriana), las lecturas asimilacionistas tampoco han podido desarticular lo medular de la novela que sigue siendo la negritud del protagonista, Ascensión Lastre. Inclusive, muchos de los lectores mismos que han querido ver en Nelson Díaz la encarnación de un proyecto social que superara toda distinción racial/racista, también han terminado reconociendo la vitalidad del personaje en cuanto a su condición de negro. Es el caso del crítico Johnathan Tittler, por ejemplo. Por una parte, éste ha comentado que "Bajo la influencia del mulato, Nelson Díaz, Lastre termina viendo la cuestión racial como un callejón sin salida, una dicotomía falsa y una barrera para la solida- 
ridad de clases" (175; traducción mía). Por otra parte, observa que las únicas dudas que caracterizan a Lastre "tienen que ver con el odio racial, y es su fuga incierta del racismo que lo rescata de ser una figura de cartón" (175; traducción mía). O sea, lo logrado del personaje se define en términos de su conciencia de ser negro. Es así que por más que se insista en el problema racial como un callejón sin salida, las experiencias de Lastre en Juyungo confirman lo acertado de lo que Gallegos Lara escribió en 1945, aunque con otro propósito: "ser negro, es ser negro."

Lo ineludible del problema racial en Juyungo también se patentiza al leer a Richard Jackson. Según este crítico,

La verdadera fuerza en Juyungo, entonces, se encuentra en la incapacidad de Lastre de poner a un lado la raza aunque Ortiz lo presenta como un negro en evolución hacia una conciencia de clase. Esta contradicción resalta la mayor ambigüedad de la novela, una que ha sido opacada por la sobrevivencia de Nelson de la guerra-el único sobreviviente del grupo de Lastreaparentemente para continuar resaltando su mensaje de la clase sobre la raza. (Black Writers in Latin America 128-29; traducción mía)

Se debe suplementar el comentario de Jackson acerca de la ambigüedad de la novela con otra acotación. Si bien es cierto que se acostumbra a identificar el mensaje principal de la novela con Nelson Díaz y sus famosas palabras de "Ten siempre presente estas palabras, amigo mío: más que la raza, la clase" (88), es también cierto que pocos han tomado en cuenta que es Nelson quien mueve la novela hacia el fin con una afirmación fundamentalmente racial: "el que no tiene de inga, tiene de mandinga" (277). De nuevo, lo racial sale a flor de piel. Por consiguiente, ni el personaje que más apunta a una sociedad sin razas, ni el autor que busca una reconciliación entre ser negro y ecuatoriano, puede borrar lo afro de sus interpretaciones sobre la identidad nacional. ${ }^{6}$

\section{Conclusión}

Como ya se ha anotado, los lectores originales de la novela eran mayormente blanco-mestizos, intelectuales urbanos de una clase media emergente, que llegaban al texto con un bagaje de determinados conceptos y nociones sobre la buena literatura y sobre lo que ésta debería representar. Aunque el mundo afroecuatoriano requería nuevas formulaciones para comprenderse cabalmente dentro del estado nacional, Ortiz-tanto como creador, como expositor de su propia creación-estaba supeditado a las expectativas de sus lectores. El desfase entre el referente afroecuatoriano y la lectura blanco-mestiza de la novela es precisamente una de las razones principales por la cual Juyungo sigue siendo un texto vital.

De hecho, y en no poca medida, $J u$ yungo y la situación general del afroecuatoriano desafían propuestas de una identidad nacional integracionista. Diego Iturralde ha recordado: 
Al concepto político de estado corresponde el sociólogo [sic] de nación, como expresión de sociedad unitaria, construida sobre un amplio consenso cultural; pero la sociedad unitaria y consensual no existe, es una ficción construida y reproducida, simbólicamente, mediante el signo del estado nacional, sujeto de una supuesta cultura nacional. (13)

Aunque Ortiz trató de acomodar su novela dentro del proyecto nacional-popular de su época, y aunque muchos lectores se han aferrado a algunos episodios que parecen negar la preponderancia de lo racial en el esquema nacional, es la modernidad (la lucha de clases), simbolizada por Nelson Díaz, que se deja absorber por el poscolonialismo (el multiculturalismo) de Ascención Lastre. En efecto, cuando el narrador de Juyungo se refiere a Lastre y dice que "Sentía que su odio racial flaqueaba” (79), el acercamiento del negro al blanco que esto implica no ha de sugerir la eliminación de las diferencias raciales sino la creación de un espacio en el cual los diferentes grupos que forman un país plurinacional y multiétnico pueden negociar el sentido mismo de la identidad, recordando que "pese a historias compartidas de privación y discriminación, el intercambio de valores, significados y prioridades, a lo mejor, no será siempre colaborador y dialógico, sino profundamente antagonista, conflictivo y hasta desproporcionado" (Bhabha, The Location of Culture, 2; traducción mía).

En conclusión, Adalberto Ortiz escribió Juyungo durante una época en que se cuidaba de no despertar antagonismos entre los grupos marginados del país. A partir de un mestizaje utópico, muchos de los análisis de más resonancia acerca de la problemática del país tendían a eliminar de sus esquemas todo lo que no se definiera en términos de la tenencia de tierras o de la distribución injusta de los bienes nacionales. Por consiguiente, la mayoría de los intelectuales más influyentes de aquellos tiempos no resaltó lo racial, lo étnico y lo pertinente al género sexual como problemas medulares de por sí. En lo que se refería concretamente a lo racial, la retórica oficial del no-racismo ecuatoriano fue suficiente para distorsionar lo afroecuatoriano, manteniéndolo en un plano primordialmente exótico y ajeno a la diáspora afroamericana. Aunque Ortiz trató de trabajar dentro de los parámetros establecidos, insistiendo en un mestizaje ilusorio, él no pudo dislocar lo afro del centro mismo de su visión del mundo. En cierta forma, las contradicciones de Ortiz ratifican lo acertado del concepto de la "doble conciencia,” según lo concibió W.E.B. DuBois:

Es una sensación peculiar, esta doble conciencia, este sentido de estar siempre mirándose a través de los ojos de los demás, de estar midiendo el alma de uno con la cinta métrica de un mundo que mira todo con desprecio divertido y con lástima. Uno siempre siente su condición dobleun americano, un negro; dos almas, dos pensamientos, dos ambiciones irreconciliables; dos ideales en guerra en un solo cuerpo oscuro cuya fuerza tenaz de por sí hace que no se lo destruya por completo. (The Souls of Black Folk 3; traducción 
mía)

Si bien es cierto que DuBois reflexionaba fundamentalmente sobre el negro de los Estados Unidos, el sociólogo, Paul Gilroy, ha constatado que, además de expresar "el punto de vista distintivo de los negros americanos," DuBois empleó su concepto de la "doble conciencia" para iluminar "la experiencia de poblaciones posesclavistas, en general" (126; traducción mía).

Lamentablemente, la amplitud de la cuestión racial todavía carece de suficientes interesados en el Ecuador. El peso de la tradición del supuesto no-racismo del país, junto con sus ineludibles contradicciones, sigue impidiendo la creación de una nueva aprehensión de lo afroecuatoriano. Por una parte, los estereotipos de siempre ofuscan el mundo complejo y vital de lo afroecuatoriano; por otra parte, el silencio y la ignorancia que caracterizan la manera en que los medios de comunicación siguen tratando al negro en general, crean la impresión errónea de que las comunidades afroecuatorianas son culturalmente estáticas y que están irremediablemente fragmentadas, sin interés en defender sus derechos y necesidades particulares. Aunque se esté lejos todavía de organizar en el Ecuador un movimiento afro parecido al indígena, Pachakutik-Nuevo País, que ganó siete diputados en las elecciones de mayo de 1996, se esperan nuevas reflexiones capaces de insertar y de mantener lo afro en el centro mismo del debate sobre la identidad plurinacional y multicultural del Ecuador, y del resto de Amé- rica. $^{7}$

\section{Notas}

1 Mi análisis de Juyungo se basa en una lectura más "cultural" que "literaria," y por lo tanto, mi intención crítica es más contextual que textual. Además, puesto que soy de la opinión de que una aprehensión cabal de lo afroecuatoriano se realizará solamente en el contexto global de la diáspora afroamericana, mi estudio sobre $J u$ yungo se mueve continuamente entre fronteras disciplinarias (i.e., literatura, historia, antropología) y geográficas (el Ecuador y el resto de América).

2 Aunque Ortiz ha exagerado al identificarse como el primero que había escrito sobre el negro en el Ecuador, no cabe duda de que ninguna obra anterior a Juyungo había alcanzado su envergadura o calidad en lo que respecta a lo afroecuatoriano.

3 Wlad Godzich ha señalado en su introducción a Aesthetic Experience and Literary Hermeneutics de Jauss: "El público también sirve como árbitro entre una obra mayor y una más reciente y, así, ofrece la base para comprender la formación de las secuencias literarias que la historiografía presentará... Por lo tanto, [...] cada generación de lectores tiene que re-escribir la historia. Esto no es un defecto de la teoría [...] sino su rasgo más liberador, puesto que asegura que ninguna perspectiva fija prevalecerá y que cada generación debe leer los textos de nuevo e interrogarlos dessde su propia perspectiva y encontrarse preocupada, a su propio modo, por las preguntas de la obra" (xii-xiii; traducción mía).

4 Comprendo que hay personas que hacen una distinción marcada entre conceptos de color y raza. En lo que respecta a lo afro, concretamente, me parece que tal separación es una distorsión que ofusca el lugar que ocupa la diáspora en la formación de las naciones americanas. No estará de más, tampoco, recordar el racismo latente de los diversos discursos "somáticos" de- 
nunciados hace más de veinte años por Jackson en su estudio seminal, The Black Image in Latin American Literature.

5 Le agradezco a Raúl Vallejo, escritor y catedrático del Ecuador, quien me ha recordado que en la cita de Cornejo se había empleado "morenos" de una manera eufemística ya que es el término que se suele utilizar socialmente en el Ecuador para "suavizar" la palabra "negro" que puede tener connotaciones peyorativas.

6 El amigo y colega Rafael E. Hernández me ha hecho ver que el nombre mismo del protagonista resalta la conflictividad comentada. Mientras que Ascención, como palabra, apunta hacia arriba, hacia una especie de salvación o superación de la condición social, el apellido (Lastre) apunta hacia abajo, sugiriendo fuerzas contrarias a una deseada armonía o reconciliación entre lo social y lo racial.

7 Coda: La elección de Mónica Chalá, afroecuatoriana, como Miss Ecuador 1996 es una manifestación más reciente de la problemática del "no-racismo" ecuatoriano. ¿Es su elección una señal de una verdadera aceptación de la negritud ecuatoriana? ¿O confirma, más bien, ciertos estereotipos como el de la mujer negra sensual? En un reportaje de la revista, Vistazo (diciembre 1995), se patentiza de nuevo la ambivalencia de actitudes y expectativas que se había destacado en Juyungo. Según declaró Mónica Chalá: "Sí, sé que eso del racismo existe en todas partes y Ecuador no iba a ser la excepción. En todo caso con mi designación se prueba que estamos dejando atrás esas nefastas posturas. La verdad es que ni yo misma creí que ganaría." A diferencia de las experiencias de las Miss anteriores, poco después de la elección de Chalá, el público se olvidó de ella. 


\section{Capitulo VI \\ Jonatás y Manuela: Lo afroecuatoriano como discurso alternativo de lo nacional y lo andino}

“... still my tie to Africa is strong... one thing is sure and that is the fact that since the fifteenth century these ancestors of mine have had a common history, have suffered a common disaster, and have one long memory... the badge of colour [is] relatively unimportant save as a badge; the real essence of this kinship is its social heritage of slavery; the discrimination and insult and this heritage binds together not simply the children of Africa, but extends through yellow Asia and into the South Seas. It is this unity that draws me to Africa." (W.E. B. DuBois) ${ }^{1}$

Jonatás y Manuela es una novela histórica de Argentina Chiriboga que se publicó en 1994 y que comparte los sentimientos más sobresalientes del epígrafe citado arriba. Africa y la conciencia de que el Ecuador pertenece a la diáspora constituyen el punto de partida de esta novela que, entre sus múltiples temas y propósitos, pretende redefinir las bases fundacionales de la República del Ecuador. Ubicada entre las últimas décadas del siglo XVIII y las primeras del XIX, la narración recupera los albores de la lucha por la independencia nacional, pero desde la experiencia de la esclavitud afro, y por lo tanto invita al lector a reevaluar las raíces blan- 
comestizas como únicas y absolutamente definitorias dentro de la construcción de la nación ecuatoriana. En efecto, esta novela es un testimonio de un Ecuador pluricultural cuyas diferencias siguen resistiendo cualquier intento de homogeneizarlas y de encerrarlas dentro de esquemas ideológicos propios de una tradición exclusivista y, por ende, antidemocrática.

En cuanto a la construcción conceptual de la nación, y de acuerdo con numerosas ideas ya comentadas en páginas anteriores, al señalar que el Ecuador es un país primordialmente andino, surge de inmediato la imagen del mestizaje como elemento medular del país, por una parte, y la geografía de las cordilleras por otra. Lo racial y lo geográfico ocupan un sitial privilegiado en lo que respecta a la identidad nacional; la mezcla entre blancos e indios junto a la omnipresencia de los Andes parecen ser la esencia misma de la nación. Este concepto del Ecuador como país andino, sin embargo, es un espejismo que hace falta cuestionar y hasta combatir. En primer lugar, las historias oficiales tanto del Ecuador como de los otros países andinos, han diluido la amplitud y riqueza raciales de la zona, especialmente en cuanto a los habitantes de la costa del Pacífico de tales países como Colombia, Ecuador y Perú. Además, y en relación a la simplificación de los conceptos raciales del área, hemos de recordar que la geografía de los tres países mencionados incluye mucho más que los Andes. De hecho, el litoral como parte integral del entorno nacional de los llamados países andinos obliga a con- siderar la presencia vital de lo afro en la composición nacional; también, es esta misma presencia afro que inserta al Ecuador, por ejemplo, dentro de la diáspora afro-afroamericana $y$, por consiguiente, sugiere una visión histórica del país mucho más compleja y enriquecedora que la tradicional que nació en el siglo XIX.

Es así que identificar Jonatás y Manuela con lo que DuBois había planteado en el epígrafe de este capítulo cobra validez al recordar:

Para cada una de las 90 millones de personas de herencia africana que vive en América Latina, hay un relato que nace de generaciones atrás. Los relatos forman un rico legado de lucha y de supervivencia. Aunque cada uno es diferente, todos tienen su comienzo en Africa. Son relatos que han sido ignorados por las historias nacionales oficiales y omitidas de los textos escolares. De hecho, esta historia no se conoce mayormente entre muchos latinoamericanos, y la mayoría de los norteamericanos ignora las contribuciones africanas a la cultura e historia de América Latina. (Collective Memory 2; traducción mía)

Aunque sigue siendo un proceso lento e irregular, el rescate de la herencia afro en el Ecuador que es tan patente en la novela de Chiriboga se está haciendo realidad fuera del texto de ficción. De hecho, entre los países donde los afrolatinoamericanos luchan por reafirmar su cultura mientras que reclaman que se les reconozca su justo lugar dentro de los sistemas legales y educacionales, se ha constatado 
que en Esmeraldas se han formado grupos como Confraternidad de Negros Ecuatorianos, La Máscara de Oro, Amigos del Bosque, Grupo de Teatro y Lamento Campesino que dan expresión a este proyecto general de reivindicación socio-cultural y socio-político (Collective Memory 3).

Sin duda alguna, la década de los años 90 de este siglo XX ha sido propicia para todo intento de redefinir los parámetros de la identidad nacional del Ecuador. Gracias a algunos levantamientos indígenas y al trabajo de varias organizaciones indígenas de este período, se está discutiendo la supuesta plurinacionalidad del país. Es en este ambiente tan cargado de pasiones e intereses contrarios y conflictivos que ha sido posible presentar lo afroecuatoriano como un componente medular de la nación, en general. Es decir, al poner en tela de juicio el centro mestizo-andino de la identidad ecuatoriana tradicional, lo afro ha podido surgir como un discurso alternativo, o si se prefiere, complementario dentro del imaginario nacional. Es esta perspectiva afrocéntrica que considero ser uno de los mayores aciertos de Argentina Chiriboga en su Jonatás y Manuela.

$\mathrm{Al}$ aceptar la idea de que la historia del africano en América "es una parte integral de la historia de las Américas" (Pescatello 12), se comprende la centralidad que ha ocupado la esclavitud en todo el continente, incluyendo la zona que algunos sectores de hoy llaman la Comarca Afropacífica (i.e., Panamá, Colombia, Ecuador y Perú). Respecto al Ecuador, concretamente, ya señalé someramente en otro capítulo los orígenes de la esclavitud que datan desde el siglo XVI. Aunque hay quienes quisieran delimitar la esclavitud como un fenómeno de trascendencia histórica al Caribe y a Brasil, vale recordar que hasta en Quito de fines del siglo XVII "abundaron las esclavas domésticas de familias medias de profesionales o de personas mayores, para las cuales resultaban casi esenciales" (Salmoral 102). Esta acotación sirve de recuerdo de que aún en las primeras décadas del siglo XVIII, en el Ecuador los esclavos "valían una verdadera fortuna. La necesidad y el estatus social lo daban ellos. Una familia noble no podía estar sin tener esclavos para que los sirvan..." (Garay, "Los negros en Guayaquil en 1850," 133). El investigador Leslie Rout también ha anotado que, según el censo de 1858 , entre mulatos, zambos y negros, este conjunto racial llegó a constituir el $28 \%$ de la población total del país (231). Con estos antecedentes históricos, el lector de Jonatás y Manuela comprenderá mejor la razón por la cual la esclavitud le ha servido a Chiriboga como un punto de arranque efectivo en la creación de un discurso alternativo de lo nacional y, por extensión, de lo andino.

Indudablemente, la presencia de lo racial en la ficción latinoamericana no es ninguna novedad, ni tampoco lo es el uso de la novela como un instrumento fundamental en la construcción de conceptos de la nación. ${ }^{2}$ La medida tan generalizada en que se ha empleado la novela como una expresión de identidad nacional a través de toda América Latina, comenzando con el mismo Periquillo (1816), la primera no- 
vela latinoamericana, resalta profundos vínculos entre raza, nación y literatura que, según ha puntualizado Kwame Anthony Appiah, caracteriza también mucho del pensamiento euro-americano desde los siglos XVIII y XIX (48). Por su parte, George Hutchinson, crítico norteamericano que escribió Harlem Renaissance in Black and White (1995), indica que por ser la raza todavía una causa determinante social de mucha envergadura en EE.UU., por ejemplo, "es inútil hablar de 'trascenderlo' o de desear que deje de existir por muy novelesco que sea" (26, traducción mía).

Aunque el análisis de Hutchinson se refiere a otro medio nacional, creo que es pertinente a la situación ecuatoriana puesto que apunta a muchas de las experiencias compartidas a través de toda la diáspora. De especial importancia para mi interpretación de lo afro y la nacionalidad del Ecuador es la insistencia de Hutchinson en la complejidad histórica del tema racial que requiere "un reconocimiento tanto del carácter nacional (y por lo tanto, híbrido) de nuestras identidades raciales como el carácter racial de nuestras identidades norteamericanas, puesto que la subconciencia nacional afecta nuestras reacciones acerca de la 'raza' como indudablemente la subconciencia 'racial' afecta nuestras ideas de la nación norteamericana" (26, traducción mía). Lógicamente, en el contexto ecuatoriano, esta misma interacción entre raza y nación se ha examinado desde hace mucho tiempo, pero siempre con miras al mestizaje clásico de blancos e indios.
En lo que se refiere concretamente a Jonatás y Manuela, las referencias de Hutchinson a la complejidad histórica y a la hibridez también invitan al lector a reflexionar sobre la simultaneidad de temas e inquietudes de la novela que mucha gente acostumbra considerar dispares y desconectados. Es decir, la preocupación por lo afro no conduce a un discurso separatista (o a un racismo al revés como algunos quisieran denunciar), sino que problematiza dos siglos de identidad nacional, indicando que la presencia afro en el Ecuador no es un tema ocioso o rebuscado, ni ha de limitarse a un plano exotista dentro de la nacionalidad ecuatoriana. En efecto, la visión que Chiriboga desarrolla en su novela es multifacética e íntimamente vinculada a todo un proceso de redemocratización que lucha por la unidad a partir de las diferencias y no de una homogeneización mítica, exclusivista y encubridora.

En el plano puramente racial, Jonatás y Manuela confirma la centralidad y representatividad general de lo afro que Alice Walker, por ejemplo, ha puesto de relieve al comentar "la manera en que escritores negros y blancos parecían escribir un solo cuento inmenso, con diferentes partes del cuento que venían de una multitud de perspectivas diferentes" (en Collins 36-37; traducción mía). Es por eso que Walker ha aseverado que ella cree firmemente que "la verdad de cualquier tema sólo surge cuando todos los elementos del cuento se combinan y que sus significados diferentes forman una nueva ver- 
dad. Cada escritor escribe las partes que se les han escapado a otros escritores" (en Collins 36-7; traducción mía).

La naturaleza dialogal del proceso de escritura tan patente en los comentarios de Walker encaja perfectamente en sociedades que se reconocen como sincréticas, heterogéneas, híbridas o poscoloniales. Sea la que sea la terminología empleada, hemos de recalcar que Jonatás y Manuela pertenece a la búsqueda de un discurso pluricultural, que para una sociedad como la ecuatoriana, es imprescindible si se espera representar cabalmente lo nacional. Y, a propósito de la relación entre lo pluricultural y lo nacional, recordemos a Ashcroft quien ha señalado que "dentro de la realidad sincrética de una sociedad poscolonial es imposible volver a una condición cultural pura y precolonial. El texto poscolonial es siempre una formación compleja e híbrida. Es inadecuado leerlo como una reconstrucción de valores tradicionales y puros o simplemente como una expresión de extranjeros o de intrusos" (The Empire Writes Back 109-110; traducción mía).

Para reconstruir la historia nacional del Ecuador, Chiriboga escoge a tres mujeres negras de tres generaciones diferentes como sus protagonistas en una época que corre desde los fines del siglo XVIII hasta el 24 de mayo de 1822, fecha de la Independencia del Ecuador. Las tres mujeres son la abuela (Ba-Lunda/Rosa), la hija (Nasakó/Juana) y la nieta (Nasakó Zansi/Jonatás), ${ }^{3}$ y su vida colectiva con todas las penurias y peripecias de la esclavitud encapsula la presencia de la diáspora dentro de la historia nacional. Sobre todo, lo que llama la atención en esta novela, es el proceso paulatino que protagonizan los negros al incorporarse dentro de su nuevo entorno. El proceso, claro está, se caracteriza por cualquier cantidad de contradicciones y conflictos en lo que respecta a la creación de un sentido nuevo de identidad. Ba-Lunda, mujer africana, capturada en Africa y llevada a América en cadenas, resiste todo intento de desafricanización; Nasakó, la hija pequeña, que también llegó a América como esclava, se siente distanciada y alejada de los orígenes, y a diferencia de la madre, su formación como persona iría a realizarse fundamentalmente en el Nuevo Mundo; y Nasakó Zansi, la nieta americana, cuya vida entera fue una búsqueda por la madre perdida, a ella le corresponde unificar el pasado y el presente, Africa y América.

Como novela, Jonatás y Manuela pertenece a una tradición literaria que ha pretendido dar expresión a la diáspora afro-afroamericana y, por lo tanto, muchos temas empleados por Chiriboga recuerdan tales textos como Raices (Roots) de Alex Haley y Changó el gran putas de Manuel Zapata Olivella. El recibir nuevos nombres en América como mecanismo de conquista y negación, el uso de hierbas para envenenar a los amos blancos, los levantamientos, las fugas, la invocación a los orishas y la voluntad inquebrantable de sobrevivir son algunos de los temas que ayudan a situar Jonatás y Manuela. Fragmentos de la novela como los siguientes 
constituyen una visión afrocéntrica de lo que significa ser negro en América:

Ba-Lunda comprendió que ahora debía ser fuerte para enfrentar un nuevo destino y planear su venganza. (17)

No contentos con quitarle la libertad, ahora le quitaban su nombre, iqué horror! Se aseó y juró vengarse. (34)

Estaba prohibida la comunicación con otras plantaciones, pero, en alas del viento, el Kan se

esparcía por todas partes, tal una palabra mágica, una pleamar de rebeldía. (51)

Olvidados de la travesía, de las caricias de sus padres, del rostro de su Africa, vivían desmemoriados por completo de su vida anterior. (98)

Desde el día en que se bifurcaron sus destinos, se sintió más esclava que antes por estar condenada al suplicio de la disgregación. (127)

En todo momento del texto, Chiriboga insiste en la lucha de los negros contra la dominación tanto física como cultural. Lejos de aquel estereotipo infame del "negrito pasivo y sumiso" que ha llenado tantas páginas de la literatura, la interpretación de Chiriboga resalta el cimarronaje como fuerza medular de la experiencia del esclavo americano. ${ }^{4}$ Pero, al mismo tiempo, la autora reconoce los peligros de un sistema esclavista que a menudo logró neutralizar la capacidad y el deseo de resistir y de rebelarse. Por eso se lee, al referirse a uno de los personajes secundarios:
"Se acostumbró a creer que las cosas siempre fueron como las veía ahora, que nunca tuvo padres ni hermanos, [...] la vida la había dejado sin memoria. [... ] Después, habló: a los jóvenes les toca luchar, yo estoy bien como esclava" (96).

Sin duda alguna, el caso más trágico de lo que se podría considerar un descarrilamiento de principios y valores frente a un sistema que vivía del comercio de la carne humana fue el de Nasakó, la madre de Jonatás. Con su nuevo nombre e identidad a cuestas-en América se llamaba Juana-, se olvidó de sus orígenes y de su razón de ser como esclava (es decir, la lucha por la liberación propia y colectiva). Lejos del ejemplo inquebrantable de BaLunda, "Juana estaba ahora ligada al mundo de los negreros; sentía el placer de los que solo (sic) aman el dinero. Asesoraba a las autoridades en la persecución y captura de los cimarrones. Andaba buscando fugitivos que había comprado" (163).

$\mathrm{Al}$ encontrar a su madre después de varios años de separación, y al descubrir la verdad de su conducta traidora, Jonatás comprendió que su familia como fuerza unificadora y baluarte de una identidad cultural se había desintegrado y, por consiguiente, era necesario crear un nuevo proyecto basado en lo rescatable del pasado (i.e., la herencia viva de la abuela, BaLunda) y las nuevas circunstancias y necesidades del presente. Es así que Jonatás logró trascender polaridades y combinó su herencia de luchadora africana con su condición de americana independentista. En efecto, mediante el ejemplo simbólico de Jonatás, se vislumbra en la novela el pa- 
pel medular que jugaron los esclavos en la creación de una América libre, pero sin caer en simplificaciones idealistas o románticas. ${ }^{5}$

No estaría demás observar aquí la medida en que la perspectiva que Chiriboga tiene sobre el negro y su adaptación a América coincide con la imagen que $\mathrm{Ni}$ colás Guillén había expresado en su famosa "Balada de los dos abuelos" de 1934. Según el poeta cubano:

Don Federico me grita,

y Taita Facundo calla;

los dos en la noche sueñan, $\mathrm{y}$ andan, andan.

Yo los junto. (Summa poética 92)

En ambos textos se celebra la capacidad de las nuevas generaciones de negros nacidos y criados en América de forjar su propia identidad a partir de sus orígenes múltiples y complementarios. Mientras que el verso de Guillén de "Yo los junto" es una afirmación de responsabilidad y de creatividad, ya que es al negro a quien le corresponde definir su ser, la novela de Chiriboga también pretende forjar la identidad afro desde su heterogeneidad. Por consiguiente, la insistencia en recuperar el pasado afro que sale a flor de piel a través de toda la diáspora constituye mucho más que un retorno caprichoso a un pasado remoto e inexistente; de hecho, es la expresión de una identidad compleja cuya autenticidad depende de un sincretismo cultural que cultiva todas sus raíces dentro de un proyecto consciente de americanización abierta, proteica y en cons- tante elaboración.

Puesto que muchas fuerzas tradicionales a lo largo y a lo ancho de toda América han pretendido borrar y silenciar esa complejidad cultural durante el último siglo y medio, volver al pasado se ha convertido en un sine qua non para aquellos americanos cuyos orígenes múltiples se han perdido en proyectos nacionales exclusivistas forjados en nombre del orden y de la armonía general. Por lo tanto, el nuevo interés en la historia que ha marcado a muchos países latinoamericanos del último cuarto del siglo XX, especialmente evidente en el "renacimiento [... de] la novela histórica" (Kirkpatrick 52), no ha sido una simple casualidad. Tales grupos marginados y subalternos como los de los negros, los indios y las mujeres reclaman su pasado porque comprenden que la recuperación del pasado perdido es imprescindible para la construcción de un futuro democrático. Gwen Kirkpatrick ha constatado:

La historiografía de las mujeres tiene como uno de sus fines el de buscar o excavar unos orígenes olvidados o sumergidos. Como el proyecto intelectual de tantos escritores e intelectuales latinoamericanos de este siglo-Mariátegui, Vasconcelos [...] - las mujeres han buscado las raíces de una cultura auténtica en el pasado. (50-51)

Volviendo a Jonatás y Manuela, las coincidencias entre los comentarios citados de Kirkpatrick acerca del feminismo y el proyecto afro de Chiriboga son clarísi- 
mas. En efecto, toda la novela apunta a una reivindicación del afrohispanoamericano como agente de cambio y creación desde la historia del continente, especialmente en el momento de su nacer republicano. Pero, el afrocentrismo que Chiriboga emplea en su novela trasciende categorías aisladas o parciales. Al convertir lo racial en lo nacional y lo nacional en lo racial, huelga insistir que Chiriboga no se detiene en polarizaciones o dualismos puesto que ella comprende que su preocupación por la raza/nación no existe en un vacío y, por lo tanto, la contextualiza abriéndose a tales complementos sociales como la clase social y el género sexual. Por eso, Chiriboga interpreta los acontecimientos de la época desde las experiencias de Jonatás, un personaje que es simultáneamente esclava (clase social), mujer (género sexual) y afroamericana (raza). La hibridez del texto permite que el lector se mueva entre diferentes centros interpretativos, poniendo en tela de juicio la historia oficial como única y absoluta fuente de autoridad. En este sentido, la novela de Chiriboga cabe dentro de lo que algunos han identificado en las últimas décadas como el poscolonialismo (Ashcroft, por ejemplo). Es decir, la nueva historia se escribe desde los márgenes tradicionales $\mathrm{y}$, así, se rompe la noción misma de los dualismos jerarquizados para crear múltiples centros simultáneos y coexistentes, los cuales se complementan y se enriquecen los unos a los otros.

No se debe pasar por alto la medida en que el poscolonialismo coincide con al- gunas metas del feminismo, y especialmente en lo que respecta a una interpretación de Jonatás y Manuela. Según se ha comentado:

El desplazamiento del centro, el desenmascarar de un poder céntrico que hace el papel de lo universal, ha sido un arma central de los discursos feministas. Por haber cuestionado el centro solar del patriarcado, el movimiento ha puesto en marcha toda una serie de desplazamientos. [...] El feminismo ha servido como elemento catalítico de una crítica cultural profunda. (Kirkpatrick 54)

El afrocentrismo, el feminismo y la democratización constituyen, entonces, los pilares sobre los cuales Chiriboga construye su visión de la nación. Recordemos que "para las mujeres negras, el considerar que las relaciones de dominación han sido estructuradas en cualquier contexto sociohistórico mediante un sistema de opresión en que se entrelazan raza, clase y género expande el enfoque de análisis de describir meramente las similitudes y las diferencias que caracterizan estos sistemas opresivos para, así, poner más atención en cómo se complementan" (Collins 222 ; traducción es mía). Puesto que Chiriboga es plenamente consciente de su condición de mujer por una parte, y de mujer afro por otra, Jonatás y Manuela termina siendo la expresión de un proyecto literario afro-feminista en el cual Barbara Smith ha destacado la necesidad absoluta de conectar la política sexual ("the politics of sex") con la política de raza y de clase ("the politics of race and class") (en 
Leitch, 90-91). Es así que se ha planteado:

La habilidad de las mujeres negras de tomar [...] expresiones individuales, no articuladas, de una conciencia cotidiana y forjarla con una perspectiva colectiva, articulada y autodefinida, es esencial para la sobrevivencia de las mujeres negras. [...] Para las mujeres negras, la lucha consiste en abrazar una conciencia que es simultáneamente afrocéntrica y feminista. (Collins 26; traducción mía)

El concepto de las múltiples opresiones y la estrecha vinculación que existe entre Jonatás y Manuela marcan la relación que las une. Sin tener todavía la posibilidad de eliminar por completo las diferencias inherentes al sistema clasista y esclavista en que ambas mujeres vivían, surge una profunda identificación entre las dos. Se recordará que Manuela era una hija bastarda y, por lo tanto, ella fue sometida a ciertos prejuicios de exclusión que la hacían más sensible a la necesidad de rebelarse contra el orden social del día. En este sentido, la lucha constante por la liberación que caracterizó a Jonatás fue recogida por Manuela como una necesidad propia. De manera que, en la novela, la lucha de Jonatás como esclava traspasa fronteras y se convierte en un componente vital dentro de una liberación múltiple: la de los esclavos, la de las mujeres, la de los hijos ilegítimos y la de las repúblicas nacientes de América. En fin, la experiencia del esclavo ya no se perfila como un fenómeno aislado o periférico en la historia, sino que se proyecta como una expresión ejemplar de la democratización de una so- ciedad pluralista y heterogénea.

La convergencia o interacción de los mundos de Jonatás y Manuela, tanto en el sentido concreto de las dos como en el simbólico, apunta a nuevos esquemas de identidad entre las razas y clases sociales que constituyen el Ecuador y América. La misma figura de Manuela Sáenz ya se define en términos de su contacto con Jonatás y, en general, con las influencias del mundo afro. El componente afro deja de ser exótico y extraño. Por eso se lee:

Paulatinamente, iba separándose del mundo blanco para entrar al de la negritud, al mundo de los colores alegres, al mundo de la fantasía. Manuela caminó hacia el espejo y, al colocarse el tejido sobre el pecho, se miró feliz, aceptando la raíz de su abuela panameña, era de ella de quien había heredado su cabellera negra. [... Y] se trataba de una nueva forma de pensar, de ser, sentirse segura de sí misma. Manuela eligió un peinado con trenzas y canutillos. (94)

De hecho, según la interpretación afrocéntrica de Chiriboga, se entiende que es Jonatás quien prepara a Manuela para su futura participación en las guerras de Independencia, pero a partir de una previa lucha contra la esclavitud. Es decir, es la criada quien prepara al ama para que ésta asuma su papel protagónico como la Libertadora del Libertador. Indudablemente, esta revisión histórica o, si se prefiere, esta reinterpretación literaria recuerda al colombiano, Manuel Zapata Olivella, quien ha afirmado: "América se negreó con los africanos, no por su piel negra, si- 
no por su rebeldía, sus luchas antiesclavistas, su unión con el indio para combatir al opresor, por sus tambores y orichas guerreros, por sus pregones, por su músculo, por su inquebrantable optimismo de pueblo vencedor" (330).

Esta imagen positiva del negro como actor dentro de la historia de América adquiere mayor importancia en Jonatás y Manuela puesto que Chiriboga demuestra que es el negro mismo quien reclamó y creó su justo lugar en la sociedad a partir de su propia definición de valor personal. Es decir, la liberación y la justicia no fueron principalmente el resultado de gestos paternalistas o de algún espíritu magnánimo de uno que otro amo. Los negros rompieron las cadenas de la esclavitud porque ellos mismos se apropiaron de su identidad, definiéndola y valorándola con confianza y orgullo. ${ }^{6}$

La creación de una identidad propia como acto de rebeldía y de radicalización frente a conceptos humillantes sale a la luz en la novela cuando Jonatás se ve por primera vez en un espejo. Su primera reacción es de repugnancia y de negación. Al comentar que "no había duda, esa fea era ella" (93), Jonatás "le lanzó un escupitajo" (93) a su propia imagen y, al hacerlo, se perdió momentáneamente en un estado de inmovilización psicológica y política, encomendándose a una supuesta bondad y generosidad de su ama, Manuela: "Comprendió, entonces, que su ama era buena; más que buena, no la había rechazado siendo tan fea, jugaban de igual, sin echarle nunca en cara su fealdad" (93). Esta ac- titud de agradecimiento sumiso no hace más que poner de relieve la aceptación de parte de las víctimas mismas de una jerarquización social que se nutría de la opresión y la injusticia.

Pero, casi en seguida, Jonatás reacciona:

Le invadió una ráfaga de angustia, pero algo que le andaba por las venas y no podía apartarlo, le afloró de pronto. Clavó los ojos en sus ojos, los vio brillantes, expresivos, gozosos; sonrió, el espejo retrató sus dientes blancos; ah, aquellas trenzas terminadas en canutos de colores la volvían atractiva; no, no soy tan fea. Al despedirse del espejo, llevó la convicción de que era bonita, que Changó sea contigo, musitó y fue a golpear el dormitorio de sus amas. (93)

Esta escena implica una reconciliación consigo misma como mujer negra. Por consiguiente, Jonatás adquiere un poder nuevo sobre su propia persona que le permitirá dinamizar sus relaciones con Manuela y con todos los demás. De hecho, después de "golpear el dormitorio de sus amas," le abren la puerta a Jonatás, y "Doña María [la madre de Manuela], por primera vez, observó detenidamente a la negrita con quien jugaba Manuela" (93). El mirar a Jonatás por "primera vez" no es una mera coincidencia porque la niña esclava ya es una nueva persona con una nueva conciencia de su propio valor, una conciencia que anuncia los comienzos de un proceso de liberación tanto para Jonatás como para Manuela. Puesto que Jonatás jamás se verá como inferior (y todo lo 
que implica ser "fea"), tampoco dejará que los demás la vean así. ${ }^{7}$

Con el cambio de actitudes, Jonatás y Manuela consolidan una relación que es simbiótica y de una ayuda mutua, aunque dentro de las limitaciones históricas del momento. Según se lee: "Ambas sentían placer al enseñar y aprender" (126); en otro momento del texto: "la blanca miró a su esclava. Sin ella volvería a sus tristezas..." (86-87); y finalmente, "Jonatás comprendió que de veras su ama la quería. Tenía clara esa idea, todo lo que proyectaba hacer en su vida era unir su destino al de Manuela, ahogar su odio contra la blanca" (87). ${ }^{8}$

Hemos de recalcar que las referencias de Jonatás a unirse a Manuela no implican una negación de sí misma. Jonatás comprende que Manuela tiene acceso a los recursos y al poder social tan necesarios para llevar a cabo el proyecto de liberar a los esclavos. Pero, Jonatás no es una mujer cínica ni manipuladora; su acercamiento hacia Manuela es el resultado de un proceso gradual que, como ya se ha mencionado, incorpora a ambas mujeres en una alianza basada en una igualdad incipiente. Es decir, el contacto, la convivencia y la colaboración entre las dos, que comenzaron cuando eran niñas, tumbaron murallas sociales tradicionales por un lado, y convirtieron a las dos mujeres en compañeras por otro, colocándolas en un camino que prometía abrirse hacia nuevas posibilidades de democracia y justicia social.

No es casual que toda esta historia desemboque en la batalla definitiva de la independencia del Ecuador, en la batalla de Pichincha del 24 de mayo de 1822. Las dos mujeres, la criada y su ama, comprometidas con la creación de un nuevo país, reivindican el papel protagónico que jugaron mujeres y negros en la creación de una América libre. Al marchar juntas por el camino de la liberación, ambas mujeres fundieron sus luchas personales (la de la esclava y la de la bastarda/adúltera) para crear un proyecto común, un proyecto republicano. ${ }^{9}$ Si los sueños y las promesas de la época independentista (simbolizados por Jonatás y Manuela) quedaron inconclusos, no sería por las nuevas ideas propiamente, sino por los detentadores del poder tradicional cuyo yugo todavía no se ha logrado romper. Pero la semilla existe, y Chiriboga la celebra en su novela híbrida, múltiple y democrática. Por medio de su visión afrocéntrica/afrofeminista de los comienzos de la nación ecuatoriana, y por extensión, de todas las naciones latinoamericanas, Jonatás y Manuela recuerda una observación del crítico, Richard Jackson:

El humanismo... se entiende como una actitud de preocupación por el hombre y por los problemas que lo acosan en su vida. La crítica humanística mide la literatura contra esta actitud. Sea una preocupación por la injusticia racial y social de un individuo o de un grupo, o una preocupación abstracta y existencial de la condición humana, una preocupación humanística por la interacción entre hombres ha sido un tema primoridal de la literatura latinoamericana desde hace mucho tiempo. (Black Literature and Humanism 
in Latin America 120 y passim; traducción mía)

Sin duda alguna, las poblaciones afroamericanas han sido actores ejemplares en esta búsqueda de justicia a través de toda América.

\section{Conclusiones}

Las diferentes interpretaciones a las que se presta Jonatás y Manuela convergen continuamente entre sí; en este sentido, Chiriboga ha creado un espacio pluralista en el cual no existe ningún discurso privilegiado o hegemónico precisamente por estar todo y todos entrelazados. Sin embargo, mientras que el modelo concebido por Chiriboga pone de relieve las múltiples relaciones cambiantes entre el individuo y la colectividad, esto no ha de sugerir la ausencia de un centro, un concepto fundamental de los diversos post-estructuralismos los cuales se han destacado por su "oposición a una ideología del individualismo y de una Verdad Absoluta" (Morris 159). Es decir, a diferencia de algunas tendencias post-estructuralistas que convierten el saber en un juego de arbitrariedades y lo desprenden de una especificidad histórica o política (Morris 159), el pluralismo que practica Chiriboga celebra la coexistencia de múltiples centros, cada uno anclado en su contexto sociocultural y vinculado con los de su alrededor. Por eso el afrocentrismo de Jonatás y Manuela es la afirmación de un centro, pero solamente de un centro entre muchos.

La tolerancia que caracteriza la perspectiva de Chiriboga, entonces, apunta a un proceso de deconstrucción de viejas "relaciones de poder previamente construidas sobre estables tradiciones binarias del poder blanco versus la falta del poder étnico" (Jehenson 124). Además, puesto que esquemas binarios tienden a basarse en posturas esencialistas, el pluralismo de Chiriboga se acerca a una identidad afro parecida a la que Aimé Césaire había conceptualizado: sincrética e impura (Clifford 59). Por consiguiente, en $\mathrm{Jo}$ natás y Manuela, no se pretende volver a un pasado africano idílico e inexistente ni recuperar raíces autóctonas que distan mucho de las vivencias propias de los negros de América Latina. De hecho, Kwame Anthony Appiah ha enseñado que ya no existe "una cultura africana plenamente autóctona ['a fully autochthonous echtAfrican culture'] que espera que los artistas la rescaten, ni tampoco existe una cultura americana sin raíces africanas" (155). Por eso, Jonatás es eminentemente ecuatoriana. Su condición heterogénea de mujer, esclava y negra la convierte en un símbolo nacional de un Ecuador democráticamente múltiple donde todos los ecuatorianos son co-partícipes en la construcción perpetua de una identidad nacional que nunca ha sido (ni jamás será) fija ni estática.

Para concluir, la perspectiva afrocéntrica (y afrofeminista) que Chiriboga ha empleado en su Jonatás y Manuela de- 
sarticula el mito del indomestizaje (y del patriarcado) como esencia nacional del Ecuador y de los países vecinos de los Andes. ${ }^{10} \mathrm{Al}$ reinterpretar la historia de los comienzos de la nación a partir de las experiencias de una esclava, Chiriboga no se encierra en particularidades aisladas o separatistas. $\mathrm{Su}$ afrocentrismo invita a nuevas lecturas de la historia nacional. Al trazar la vida de Jonatás, se comprende que la nación como tal no es una síntesis sino un proyecto sincrético eternamente por hacerse.

\section{Notas}

1 Citado por Paul Gilroy en su The Black Atlantic; la traducción al español sería: "mis vínculos a Africa todavía son fuertes... lo cierto es el hecho de que desde el siglo XV estos ancestros míos han tenido una historia común, han sufrido un desastre común, y tienen una larga memoria... la insignia del color es relativamente insignificante salvo como una insignia; la verdadera esencia de este parentesco es su herencia social de la esclavitud; la discriminación e insulto; y esta herencia vincula no sólo a los hijos de Africa, sino que se extiende a Asia amarilla y llega hasta los Mares del Sur. Es esta unidad que me atrae a Africa." (La traducción es mía.)

2 Para una buena explicación de esta idea, véase Foundational Fictions de Doris Sommer.

3 Así son los dos nombres de cada personaje-el de origen africano y el de la esclavitud en América.

4 Digo aquí "americano" en pleno sentido continental, inmerso en la diáspora. El mundo captado por Chiriboga no está lejos del de Frederick Douglas, esclavo de EE.UU., quien enseñó a otros esclavos a leer como forma del cimarronaje. Según explicó Douglas: "Cada momento que pasaron en aquella escuela, corrían el riesgo de ser detenidos y de recibir treinta y nueve latigazos. Llegaron porque querían aprender. Su capacidad intelectual había sido sacrificada por sus amos crueles. Habían sido encerrados en una oscuridad mental. Yo les enseñé porque hacer algo que parecía mejorar la condición de mi raza era la felicidad de mi alma" (121; traducción mía).

5 Es de notar que a pesar de la preocupación por la raza tan manifiesta en Jonatás y Manuela, Chiriboga evita esquemas esencialistas y biologistas. La perspectiva de Chiriboga recuerda a Kwame Anthony Appiah quien ha denunciado el uso absolutista del concepto racial que conduce a un desconocimiento de la gran diversidad que caracteriza a la gente afro. Según él ha escrito: “'La raza' nos incapacita porque propone como base de una acción común la ilusión de que la gente negra [...] está aliada por naturaleza y no por el esfuerzo; por lo tanto, nos deja sin la preparación necesaria para manejar los conflictos intrarraciales que surgen de las situaciones tan disímiles de la gente negra [...] en diferentes partes de la economía y del mundo" (176; traducción mía).

6 Me parece que es este aspecto protagónico y de "afirmación" del negro (sin ser artificial o forzado) lo que distingue la novela de Chiriboga de la mayoría de los textos escritos por los ecuatorianos que, a pesar de su solidaridad para con los negros, no se identifican como afroecuatorianos.

7 Patricia Hill Collins señala que la literatura escrita por mujeres negras ofrece la visión más amplia de las luchas de las mujeres negras por formar sus propias definiciones positivas frente a imágenes denigrantes sobre la mujer negra (83). Sin duda alguna, Chiriboga está vinculada a este proyecto de reivindicación. En cierta medida, el retrato que Chiriboga elabora de Jonatás recuerda a Maria Stewart, una esclava norteamericana, también de comienzos del siglo XIX, quien "no se contentaba con identificar la fuente de opresión sufrida por la mujer negra. Ella les insistió a las mujeres negras que forjaran sus propias definiciones de firmeza de voluntad y de independencia” (Collins 3). 
114 / Michael Handelsman

8 La relación entre Jonatás y Manuela (criada y

nece a un proyecto visto en obras de otras esama) que Chiriboga elabora en la novela perte-

critoras latinoamericanas que han tratado de 


\section{Capitulo VII \\ Del mestizaje al "proceso de comunidades negras": reflexiones sobre la evolución de una política afrocéntrica en el Ecuador}

recrear la interacción que ha dejado profundas marcas en las relaciones entre mujeres de diferentes clases sociales. Miriam Yvonne Jehenson se ha referido a autoras como Ocampo, Gambaro, Allende, Garro, Castellanos, Poniatowska y Piñón. Aunque ha habido en algunos casos un "colonialismo materno," Jehenson resalta que las relaciones entre esas mujeres se han caracterizado por una intimidad honda y genuina (19).

9 A diferencia de muchas escritoras cuyos personajes femeninos pocas veces tienen opciones positivas en sus luchas respectivas por realizarse plenamente como seres humanos, tanto Jonatás como Manuela no se pierden en la locura o la muerte como únicas formas de escape o de liberación. Para un análisis elaborado del tema del encierro o del confinamiento sufrido por las mujeres en la literatura, véase Talking Back: Toward a Latin American Feminist Literary Criticism de Debra A. Castillo (24).

10 Especialmente pertinentes a este análisis sobre el indomestizaje son las observaciones del antropólogo, Norman E. Whitten, Jr., quien ha señalado una importante distinción entre la política cultural de Jaime Roldós y la de Osvaldo Hurtado, dos ex-presidentes del Ecuador. Según Whitten: "Mientras que la posición pública e ideológica tanto de Roldós como de Hurtado desafía una doctrina de la supremacía blanca, la posición de Roldós incorpora al blancojunto con el negro a una nación de diversidad en la cual el sufragio para todos debe ofrecerse igualmente. La posición de Hurtado, aparentemente contraria a la de Roldós, perpetúa el conflicto más hondo entre una síntesis étnica y un pluralismo étnico" (Cultural Transformations... 778; traducción mía). 
"Unlike the black heroes used by white writers to symbolize nation, religion, or national culture, true black heroes today are idolized by blacks because like the maroon heroes of old, they represent heroic insistence on their own societal values rather than somebody else's." (Richard L. Jackson $)^{1}$

Ya he señalado en capítulos anteriores la medida en que el mestizaje se considera un proceso de blanqueamiento. A continuación se examinará otro proceso, el que se identifica como el "Proceso de Comunidades Negras" y que se proyecta como una respuesta contestataria frente a la tradición mestiza. El epígrafe de arriba pone de manifiesto algunos de los componentes principales que caracterizan la política afrocéntrica que se está desarrollando hoy en el Ecuador, y sobre todo en Esmeraldas. Volver a la tradición de los palenques (por eso la referencia al cimarronaje) para insistir en los valores particulares de los negros como una afirmación étnica por un lado, y como un modelo de resistencia activa contra las fuerzas tradicionales de apropiación ajena por otro lado, constituye un testimonio más de la constancia de los afroecuatorianos por defender la legitimidad de su presencia en el conjunto nacional.

A diferencia de aquella ambivalencia racial ya analizada al estudiar Juyungo de Adalberto Ortiz, la firmeza de algunos sectores afroecuatorianos actuales sugiere una radicalización en cuanto a la representación que el negro hace de sí mismo y de su situación en el Ecuador. Por ejem- plo, Juan García Salazar, un dirigente del pueblo negro ecuatoriano, no vacila al proclamar que el Ecuador es un país racista y que para las comunidades negras es hora de "atrincherarnos, apalencarnos" (Samaniego Ponce 9A). ${ }^{2}$ Esta posición de desafío dista mucho de las fórmulas mestizas (o integracionistas) que procuraban "acomodar" al negro dentro de la nación ecuatoriana. Es así que se ha reconocido un discurso negro que a nivel nacional insiste en los poderes positivos de la negritud y en los efectos negativos de la explotación e injusticia impuestas por blancos y mestizos (Whitten, Jr. y Quiroga 309). Más concretamente, se ha escrito:

La población negra del Ecuador se está extendiendo en cuanto a su número, se está diversificando en los sectores abiertos al desarrollo negro y está buscando nuevas y mejores oportunidades. Los vínculos entre la gente negra en áreas rurales y urbanas se están estrechando mientras que la infraestructura nacional crece. Algunos movimientos negros ligeramente articulados a través de las provincias de Esmeraldas e Imbabura-Carchi, y grupos de Ibarra, Quito y Guayaquil responden a la retórica nacional del mestizaje con sus discursos internacionales, nacionales, regionales y locales de la negritud. (Whitten, Jr. y Quiroga 312; traducción mía)

La yuxtaposición de discursos, el uno supuestamente nacional/mestizo y el otro abiertamente múltiple/afrocéntrico, pone de relieve algunas contradicciones y tensiones propias del debate nacional/plurinacional del Ecuador. Aunque hay los que insisten que el mestizaje es la verdade- 
ra expresión de la pluralidad latinoamericana (la raza cósmica, según Vasconcelos) al mismo tiempo que denuncian lo afro como una tendencia separatista y aislada, se descubre lo inverso. Es decir, el mestizaje se desarticula al fundirse dentro de lo nacional mientras que lo afrocéntrico se expande al insertarse en la diáspora. El paradigma revela un contraste marcado entre lo estático (lo nacional como una identidad fija y esencialista-la "ecuatorianidad," por ejemplo) y la fluidez (lo transnacional que abre la identidad ecuatoriana a definiciones no fijas y siempre en discusión). No parece haber duda de que la experiencia transnacional o diaspórica del afroecuatoriano ha contribuido a la noción de que la identidad es un proceso; por lo tanto, el "Proceso de Comunidades Negras" sugiere que el negro ha de ser un actor clave en el debate sobre la plurinacionalidad del Ecuador.

Mis referencias a tales conceptos como el mestizaje, lo afrocéntrico, lo nacional, lo transnacional y la plurinacionalidad son un recuerdo de que "Nada se puede saber y conocer si no es a través del uso y manejo del lenguaje, que trae en sí las descripciones y nociones respecto al mundo. Sin embargo, es necesario re-articularlo para saber y conocer lo que aún no se sabe y no se conoce" (Rivera-Rodas 4). En efecto, el afrocentrismo se proyecta como un discurso que posibilita una rearticulación del lenguaje "para tener acceso a una reflexión renovadora, es decir, a formas nuevas del saber y conocimiento" (RiveraRodas 5). Dentro de este proyecto de rearticulación, se comprende que a diferencia de los que han manejado conceptos tradicionales sobre la raza como un fenómeno estrictamente biológico, los afroecuatorianos ofrecen propuestas más complejas. Se ha observado que

como resultado del colonialismo, del imperialismo, de la esclavitud [...] y de otros sistemas de dominación racial, los negros comparten una experiencia común de opresión. [Por lo tanto...,] hay valores afrocéntricos compartidos que están difundidos en la estructura de la familia, las instituciones religiosas, la cultura y la vida de comunidad de los negros en diversas partes de Africa, el Caribe, Sudamérica y Norteamérica. (Collins 206; traducción mía)

La misma complejidad conceptual se vislumbra al leer: "El concepto de una 'cultura afro-latinoamericana' emerge en el Ecuador en 1992, y resalta las tres constantes que caracterizan a los negros modernos que mantienen en el país sus dinámicas y tradicionales vivencias: los negros son de 'Latinoamérica'; vienen de Africa; y son negros" (Whitten, Jr. y Quiroga 311; traducción mía).

De modo que el proyecto afrocéntrico como un proceso de forjar una identidad encuentra en la diáspora una amplitud de criterios y de experiencias que vincula lo racial con lo económico, lo político, lo social y lo cultural. Esta nueva lectura de lo que es la negritud garantiza que lo afro funcione (y que se comprenda) simultáneamente en varios niveles. Por eso, Paul Gilroy ha afirmado que "la diáspora es todavía indispensable si se piensa desta- 
car la dinámica política y ética [ the political and ethical dynamics] de la historia no terminada de los negros del mundo moderno" (80; traducción mía). De ahí surgen los discursos de la negritud que según Whitten, Jr. y Quiroga, dos antropólogos a quienes ya he citado, son "internacionales, nacionales, regionales y locales" (312).

La comprobación de la universalidad de la situación de los negros se patentiza en un comentario hecho por Barley Gayle, dirigente negra de Costa Rica:

En 1992 me decidí a crear la FUSCAL $[\ldots]$ debido al fuerte interés $[\ldots]$ sobre el por qué la población negra no es visibilizada en todos los ámbitos de la vida nacional, y sobre todo el por qué cada vez que se hacía, el referente era y es el $<<$ rice and beans $>>$ o el $<<$ carnaval $>>$, o peor aún, se resaltan algunos rasgos físicos (como el color de la piel), de tal manera que denigran nuestra condición humana. Me preguntaba por qué no aparecemos en los censos, [...] por qué sólo se habla de los negros de Limón como si solamente ahí existiéramos. (en Berron 29)

Estas mismas inquietudes sobre la exclusión que sufren los negros podrían haber sido expresadas por un afroecuatoriano. De hecho, son precisamente las que han impulsado en parte el "Proceso de Comunidades Negras" y la campaña que pretende reapropiar la Comarca Afropacífica.

\section{"El Proceso de Comunidades Negras del Norte de Esmeraldas"}

En lo que se refiere al siglo XX, el in- terés en lo negro ha pasado por tres etapas, a saber: el negrismo, la negritud y el afrocentrismo. Brevemente, el negrismo fue un movimiento europeo de las primeras décadas del siglo durante las cuales los intelectuales y artistas (como Picasso) volvieron la atención a Africa en busca de nuevas musas de inspiración. En el negrismo predominaban el exotismo y el primitivismo. En cuanto a la negritud como movimiento de los años 30 y 40 , un grupo de intelectuales africanos y afrocaribeños, principalmente, intentó sacar lo afro de aquel primitivismo superficial que fue establecido anteriormente por los artistas blancos de Europa. Para Leopold Senghor y sus compañeros, Africa y lo afro constituían las bases de una civilización rica en tradiciones e historia y no un mero depósito de curiosidades que sólo servía para las exposiciones de los museos occidentales. A pesar de los avances realizados por el movimiento de la negritud en lo que respectaba a la difusión de las culturas afro, algunos críticos posteriores han lamentado la orientación excesivamente intelectual que marcaba su producción. De ahí surgió el afrocentrismo que ha querido convertir lo negro en algo más que un movimiento artístico e intelectual. ${ }^{3}$

Dentro de este esquema histórico, se patentiza una gradual politización de intereses y objetivos, un hecho que pone de manifiesto la evolución del ya mencionado proceso que interesa estudiar aquí. Ya lejos de aquel negrismo de corte europeo destinado sobre todo para los museos, el afrocentrismo emergente del Ecuador 
apunta a las cámaras legislativas del país. Por lo tanto, el proceso como tal es un hacerse continuo que se opone a cualquier proyecto que quisiera mantener lo negro en el plano de un "folklore" que erróneamente se ha entendido como una colección de vivencias estáticas y hasta muertas.

Los documentos que se examinarán a continuación son una muestra actual que confirma la vitalidad de los pueblos afroecuatorianos, tanto por su manejo del concepto de proceso como por su identificación con la diáspora afro-afroamericana. El primer texto es una especie de manifiesto intitulado "Algunos de los derechos que a los negros nos gustaría tener en la constitución," firmado por el "Proceso de Comunidades Negras del Norte de Esmeraldas."4 Lo que sale a la luz de inmediato es el manejo de una doble identidad, la de ecuatorianos y la de negros, que se mueve continuamente entre un "nosotros" nacional (Ecuador) y un "nosotros" afro (el pueblo negro): "La constitución Nacional es la Ley [sic] más importante que tenemos los ecuatorianos [...]"; y en seguida, se refiere al "pueblo Negro del Ecuador [que] debería tener por lo menos los siguientes derechos [...]" (1). Este desdoblamiento subvierte el concepto esencialista de una nacionalidad unida ya que entrelaza el "nosotros" de lo que es común a todos y el "nosotros" de las diferencias. La fluidez entre las dos voces no es una negación de la nacionalidad sino una afirmación de la condición pluralista de todos los ecuatorianos. En cuanto a los negros, son afroecuatorianos cuya identidad no se expresa con un guión entre las diferencias. Es decir, son afroecuatorianos y no afroecuatorianos ya que el guión denotaría una separación o una ruptura dentro de una identidad que ahora se define como entera e íntegra.

En cuanto a los derechos reclamados en el manifiesto, hay siete: derechos culturales, derechos de participación, derechos a la organización, derecho al territorio, derecho al desarrollo, derecho al medio ambiente y derechos políticos. Los derechos culturales tienen la etnoeducación como eje referencial. Al reconocer sus diferencias dentro del conjunto nacional ecuatoriano, se rechaza la tradición mestiza de la asimilación cultural y declara: "Que existimos comunidades Negras con una cultura y tradiciones que el gobierno y la sociedad ecuatoriana deben proteger, respetar y promover" (1). Pero, la propuesta no se queda en un plano teórico ya que el pueblo negro acepta la responsabilidad de educarse según sus circunstancias: "La educación para nuestros hijos debe tener en cuenta nuestra realidad: los lugares donde vivimos, nuestra verdadera historia, la cultura de nuestro pueblo. Queremos que el estado nos reconozca el derecho a tener nuestros propios sistemas de educación. La etnoeducación" (1).

El reclamo viene acompañado de la voluntad de actuar y, al asumir el rol protagónico de agentes del cambio social, uno comienza a liberarse de la dependencia cultural mientras que se aspira a tomar control de una de las instituciones fundamentales del Estado que ha dirigido la 
creación/invención de la identidad nacional. En lo que se refiere específicamente al norte de Esmeraldas, el reclamar los derechos culturales mediante un sistema autónomo de la etnoeducación no ha de interpretarse como un acto separatista sino como un reconocimiento de un sistema oficial de educación que ha fracasado. En un artículo publicado el 4 de agosto de 1997 en El Comercio de Quito, se denunció el abandono que la provincia esmeraldeña ha sufrido desde hace mucho tiempo: "1.000 niños están sin escuela" (D3). De hecho, el abandono oficial del Estado ecuatoriano sigue siendo tan extremo en el norte de Esmeraldas que la identidad nacional ecuatoriana corre el riesgo de desaparecer entre los habitantes de la región. Es así que dicho reportaje periodístico señaló: "Los menores también están más familiarizados con el himno nacional de Colombia, pues las notas del himno ecuatoriano casi no hay donde cantarlo" (D3).

De manera que si hay un peligro de fragmentar la nación, será más por la negligencia del Estado que por las aspiraciones culturales particulares de algunos ecuatorianos. 5 "El Proceso de Comunidades Negras del Norte de Esmeraldas" es un reconocimiento de la capacidad de los diferentes pueblos ecuatorianos de forjar su destino, por una parte, y una afirmación de su voluntad de llevarlo a cabo, por otra.

El deseo de protagonizar sus propias luchas dentro del campo de la educación coincide con el reclamo que se hace de los derechos de participación y de los derechos a la organización, la segunda y la tercera categorías tratadas en el manifiesto que estoy comentando. En no poca medida, lo que impulsa el "Proceso de Comunidades Negras" es su compromiso a construir una nueva nación en la cual las relaciones entre los diferentes sectores del país, incluyendo las que todos tienen con el Estado, dejen de ser jerárquicas. La plena participación del pueblo negro en su propio desarrollo exige estructuras políticas, económicas y culturales que sean horizontales, una propuesta que apunta a la democratización del Ecuador. Por eso se ha afirmado: "El pueblo negro tiene derecho a participar en las decisiones que tengan que ver con la vida de nuestras comunidades [...]. Tenemos derecho a pedir información a las instituciones privadas y entidades del Estado sobre los programas que estén implementándose en nuestros territorios y en general de todo lo que necesitamos conocer" (1).

La participación activa que el pueblo negro reclama también revela un resurgimiento de confianza en sí mismo. Digo "resurgimiento" porque hay un reconocimiento creciente de las tradiciones del pasado afroecuatoriano que fueron profundamente marcadas por el cimarronaje. Ante el estereotipo racista del "negro vago," "El Proceso de Comunidades Negras" rescata modelos de un comportamiento rebelde y autónomo para, así, reapropiarse de su pasado, su presente y su futuro. Es en este contexto que Juan García Salazar afirmó en una entrevista en 1997:

Para toda América Latina vinieron cerca 
de 11 millones de negros. Si los negros fuéramos vagos, ¿por qué se tomaron la molestia de traer 11 millones de negros a pasear a América Latina? Entonces, vaya si son vagos estos españoles. No vinimos de Africa a pasear, vinimos a trabajar y nosotros somos concientes que los capitales que formaron el patrimonio de estas naciones fueron el producto del trabajo de mano esclava. (Samaniego Ponce 9A)

Pero las miras hacia el pasado no han de sugerir algún paliativo retórico que solamente sirva para amortiguar el sufrimiento y la desesperación actuales mientras se espera morir en paz. El pasado al cual el afroecuatoriano se remonta más bien lo conduce a la acción puesto que, por una parte, siente su relación con los cimarrones de ayer, y por otra parte, comprende que su liberación (la de todos los negros de todos los tiempos) sigue siendo un proyecto por hacerse. Además, el compromiso para con los antepasados lleva consigo la convicción de que éstos habían forjado formas alternativas de organización (y de lucha) que los negros de hoy deben utilizar. De manera que se consideran el pasado y el presente íntimamente vinculados: "Podemos formar organizaciones de negros que respondan a las propuestas políticas ancestrales de nuestros antepasados, Comunas, Palenques, Comarcas, grupos de mantenimiento y difusión cultural y otros, para trabajar por el bienestar de nuestra población Afroecuatoriana" (1).

La identificación con los antepasados también da legitimidad al reclamo del derecho al territorio. Según razonan los voceros del "Proceso de Comunidades Negras," "Los Territorios Ancestrales del Pueblo Negro deben tener la protección del Estado para que siempre estén en manos de las Comunidades y Organizaciones $\mathrm{Ne}$ gras y poder garantizar la propiedad de los territorios Ancestrales para nuestros renacientes" (2). El derecho actual se fundamenta en la presencia ancestral de hace siglos, la que antecede la creación del Estado ecuatoriano que nació en el siglo XIX. ${ }^{6}$ Lógicamente, sin ser dueños de sus tierras, los afroecuatorianos jamás podrán ser libres ni dueños de sí mismos. Como algunos dirigentes negros han puntualizado, el territorio es

el espacio de vida donde se crea y se recrea la cultura del pueblo negro. El territorio está compuesto por lo tangible como ríos, bosques, esteros, playas, mar, animales, plantas; y lo intangible como mitos, leyendas, cuentos, magia, ritos. En definitiva, el conocimiento y saber ancestral. ("II Encuentro Afro Binacional...” 10)

Al insistir en que el gobierno ecuatoriano reconozca formalmente "la propiedad de los territorios donde vivimos," y que "el Estado busque soluciones para las comunidades que han perdido sus territorios por las invasiones de colonos o de compañías madereras, camaroneras y mineras" (2), el pueblo negro está constatando que el derecho al territorio es imprescindible si espera gozar también de sus derechos al desarrollo, al medio ambiente $y$, en general, a sus derechos políticos. Frente a los intereses económicos y políticos de 
siempre que se conocen por su costumbre de fijarse sobre todo en las ganancias y el poder, el pueblo negro plantea la cuestión territorial en términos que trascienden intereses particulares y espacios geográficos aislados. "El Proceso de Comunidades Negras" adquiere su verdadera importancia cuando se lee/se interpreta su llamada como una expresión representativa de una lucha global contra aquellas fuerzas del poder que siguen sacrificando a pueblos enteros en nombre del progreso y de la eficiencia. Exigir su derecho a ser co-partícipe en el proceso de tomar decisiones sobre la distribución de recursos humanos y naturales pone en jaque todo un sistema hegemónico que ha preferido que las mayorías de cada sociedad fueran receptores pasivos en vez de actores dinámicos en la construcción y en la evolución de sus países respectivos. Al leer, por ejemplo, "Las comunidades negras debemos participar en las decisiones que se tomen sobre el medio ambiente en nuestra región, para evitar que se cause daño a nuestros recursos naturales" (2), se comprende la medida en que "El Proceso de Comunidades Negras" aspira a dinamizar las relaciones tradicionales entre los pueblos y el Estado. En efecto, lo que se propone en el Ecuador es que el Estado deje de ser un guardián o una especie de pater familias (cuando no un craso explotador de carne humana) frente a un pueblo supuestamente compuesto de niños indefensos o de incompetentes para, así, dedicarse a garantizar las condiciones necesarias en las cuales el pueblo negro (y todos los demás pueblos dentro y fuera del Ecuador) pueda asumir plenamente las responsabilidades inherentes a la libertad y a la democracia.

\section{La Comarca Afropacífica y la consolida- ción de la identidad del pueblo negro}

La proyección transnacional de "El Proceso de Comunidades Negras del Norte de Esmeraldas" se hace evidente al leer las memorias del II Encuentro Afro Binacional Colombo-Ecuatoriano que se celebró entre el 30 de mayo y el 1ro. de junio de 1997 en San Lorenzo, Esmeraldas. La misma insistencia en la historia y en las tradiciones ancestrales ya comentada arriba sale a flor de piel en el texto del II Encuentro. Según se lee: "La población negra existe desde antes que se constituya el Estado Ecuatoriano. Por tanto su derecho es ancestral y está por encima del derecho patrimonial del Estado" (2). Al remontarse a los ancestros como base de sus derechos y de su identidad, se rompe con los esquemas oficiales de la nacionalidad y con las normas de comportamiento que cada país espera de sus ciudadanos (la lealtad y el patriotismo, por ejemplo). A riesgo de ser acusados de antipatrias, los participantes del Encuentro han convertido la raza en uno de los factores definitorios de su identidad y, de esta manera, han puesto de relieve la arbitrariedad de las fronteras nacionales creadas, en parte, para imposibilitar la solidaridad entre pueblos con historias comunes. Por eso la delegación afrocolombiana había planteado 
en su intervención:

La unidad es un aspecto prioritario para la recuperación de los derechos territoriales en todos los asentamientos ubicados en la Comarca Afropacífica. La responsabilidad de los actuales actores es abrir los caminos necesarios y tratar de eliminar aquellas líneas que separan unos pueblos de otros. Consolidar la identidad del pueblo negro y su relación armoniosa con la naturaleza. (3)

Indudablemente, enmarcar la lucha de los pueblos negros en la diáspora afroamericana resulta ser un mecanismo efectivo para construir alianzas frente a un tradicional abandono de parte de las sociedades mayoritariamente mestizas. Para los afroecuatorianos que han tenido que luchar perennemente contra una marginalidad general claramente manifiesta en la falta de servicios básicos como la construcción de escuelas y de caminos en la provincia de Esmeraldas, por ejemplo, la Comarca Afropacífica les ofrece una base amplia de apoyo y de solidaridad. De ahí los pronunciamientos de la delegación afroecuatoriana: "El Estado no respeta los derechos de la población negra [...]" (4); "El Estado ha hecho grandes concesiones de tierra a colonos manabitas que tienen mejores condiciones económicas que el pueblo negro. Por esa razón el proceso de colonización avanza en forma rápida” (4).

Ya lejos de épocas en las cuales los representantes del pueblo afroecuatoriano se aferraban a una ecuatorianidad que supuestamente los sacaría del anonimato y del olvido, los participantes del II Encuen- tro Afro Binacional han aceptado su relación antagónica con gran parte del Ecuador no afro. Según sus declaraciones:

El concepto de negritud es válido para diferenciar el accionar político de la comunidad negra de la otra cultura. La sustentación de este término es el elemento de la historia común, una forma de ver y de estar en el mundo, a partir de elementos heredados y recreados que forman parte de la etnia. No es una concepción racista sino una forma distinta de mirar la vida. Un negro diputado no es lo mismo que un diputado que trabaja por el pueblo negro. La nación negra corre el riesgo de ser olvidada si no concibe al mundo en su real dimensión. (7)

Posiciones tan desafiantes como la que acabo de citar ponen al descubierto un rotundo rechazo del mestizaje integracionista que tanto ha influido en el concepto tradicional de la nación ecuatoriana. En cierta manera, sin embargo, parece que la eliminación de unas fronteras viene acompañada de nuevas divisiones. Es decir, mientras que la diáspora permite que los pueblos negros trasciendan sus límites nacionales, se corre el riesgo de destruir otras posibles zonas de contacto que serán esenciales si se espera construir sociedades realmente capaces de funcionar de acuerdo a su condición de multiculturales y plurinacionales.

Pero existen heridas profundas y no vale armar enjuiciamientos precipitados ya que desde hace mucho tiempo hay divisiones y fronteras. Por eso se ha observado: "El negro no ha entrado en la sociedad 
dominante no porque no ha querido sino porque no lo han dejado" (8). Para entender mejor las propuestas aparentemente extremistas del II Encuentro, conviene considerar un concepto que parece servir de punto de partida: "Si bien hay que tomar en cuenta la globalización no hay que descuidar la propia cultura que parte de la relación del hombre con la naturaleza, con los demás y con la religión" (8). Mientras que la referencia a la globalización es una indicación de que no se pretende aislarse del resto de la sociedad, hay también la advertencia de la necesidad de contextualizar las relaciones según las circunstancias propias de cada grupo social. De esta manera se evita cualquier tendencia de homogeneizar lo que es por naturaleza heterogéneo. ${ }^{7}$ De hecho, hasta el pueblo negro mismo se caracteriza por su diversidad: "El pueblo negro es diverso en lo étnico. Existe diversidad entre las comunidades del Pacífico y del Caribe y no se puede pensar en una homogeneización" (9). Por consiguiente, lo afro no se configura como una expresión de purezas raciales desconectadas de otras influencias sino como el reconocimiento de las diferencias culturales que coexisten en espacios conflictivos donde continuamente hace falta renegociar identidades y fronteras, sean éstas políticas, económicas, geográficas, sociales o culturales.

La articulación de propuestas que defienden los intereses propios de los pueblos negros en un mundo de constantes renegociaciones requiere un profundo sentido de identidad, una identidad fundamentada en la historia vivida por los antepasados para, así, no caer víctima de un desarraigo cultural. Por eso, tanto "El Proceso de Comunidades Negras" como las memorias del II Encuentro Afro Binacional Colombo-Ecuatoriano resaltan la urgencia de defender la territorialidad y la cultura afro. Por una parte se explica que "La territorialidad determina el aspecto fisico de una cultura cuyos elementos vivos generan cambios. De manera que no hay cultura sin territorio" (5-6). Por otra parte, se declara que la cultura "Es el 'hilo conductor' que rompe todas las fronteras y determina el accionar, pensar y sentir en la construcción de las aspiraciones y valores, individuales y colectivos, del pueblo negro" (11).

Lo que podría haber sugerido un proyecto separatista (por no decir racista), entonces, se ha de entender como una proyección afrocéntrica desde la cual se construye un modus operandi consecuente con las necesidades y experiencias definitorias de los negros, las mismas que serán la sustancia vital de cualquier aporte que los afroecuatorianos puedan ofrecer tanto por su propio bien como por el bien de todos los ecuatorianos. Al evaluar los planteamientos reivindicativos del II Encuentro Afro Binacional desde esta perspectiva de afirmación de derechos y de responsabilidades, se comprende mejor la fuerza simbólica y práctica que ejerce la tradición del palenque para los negros. De hecho, a través de todo el documento presentado por los delegados colombianos y ecuatorianos del II Encuentro Afro Binacional, el palenque se perfila como una especie de 
sine qua non. Por eso, se ha señalado que "La construcción de palenques tiene dos finalidades: la una para buscar la libertad y la otra para rescatar la cultura del pueblo negro" (4).

Huelga recordar que la creación de los palenques tiene una larga historia en las Américas, constituyendo un testimonio concreto del valor inquebrantable de los pueblos negros en su lucha por la libertad. Pero, más que un escondite donde los cimarrones pudieron protegerse contra la esclavitud o la opresión, en general, el palenque se convirtió en un espacio desde el cual los negros mismos asumieron la responsabilidad de forjar su propio sentido de la vida. De manera que, para el imaginario afro, el palenque significa construcción, la voluntad de ser y de hacer, la comprobación de que los negros son actores y agentes de la creación de sociedades libres y autosuficientes.

En lo que se refiere a la concepción misma del lugar que los negros ocupan (y el que han ocupado) en la nación ecuatoriana (y colombiana), considero de mayor importancia el hecho de que los participantes del II Encuentro Afro Binacional no evocan las tierras lejanas y hasta míticas de Africa como principal medio de afirmación cultural y de acción. Aunque Africa siempre estará presente como legado histórico-cultural, son los palenques americanos los que contienen las semillas del pueblo afroecuatoriano. Ya lejos de las tendencias mistificadoras del movimento negrista de comienzos del siglo XX, o de los discursos a menudo idealizados de al- gunos expositores de la negritud de mediados de este siglo, los afroecuatorianos de hoy están anclando sus propuestas en la historia y en el presente de su América. Puesto que el palenque americano (la historia vivida) ha desplazado a Africa (la mitología soñada) en el discurso afrocéntrico de los ecuatorianos y colombianos, por ejemplo, ha sido posible rescatar una actitud propia del pasado que garantiza que toda protesta y todo reclamo de derechos sean una expresión legítima de los intereses generales de la nación. ${ }^{8}$ Posibles tergiversaciones aparte, la lucha actual no implica separatismo o antipatriotismo siempre que la patria sea democracia; los afroecuatorianos son del Ecuador, pero son de un Ecuador que ellos insisten en definir desde el palenque, o si se prefiere, desde la Comarca Afropacífica ya que "se llegó a concluir que la participación en organismos como el Congreso puede perjudicar a las organizaciones negras. El camino más adecuado es el palenque, un espacio de reflexión y expresión propio de este pueblo" (10). Al fin de cuentas, esta nueva definición tiene sus bases en los diversos pueblos que conforman al Ecuador pluricultural y plurinacional, constatando que la verdadera democracia ecuatoriana sólo se encontrará en su multiplicidad y no en las estructuras privilegiadas de raigambre colonial/neocolonial.

\section{La Revista cultural esmeraldeña como expresión pionera de "El Proceso de Co- munidades Negras"}

Inicio el análisis de esta sección con 
un comentario más del documento que acabo de estudiar:

En Ecuador existen algunos grupos que dicen representar a los negros del Ecuador. Sin embargo, a veces la realidad es diferente. Los hermanos del norte sienten desconfianza de los intelectuales. Por eso consideran que se debe organizar un gran encuentro en el que participen las bases del pueblo negro. (9)

Lo que cabe resaltar de esta cita es el proceso de democratización que parece estar impulsando a algunos sectores afroecuatorianos dentro de sus propias comunidades. Es decir, la plena participación del pueblo no se perfila solamente en términos de negros contra blancomestizos, sino también del pueblo contra todos los que le nieguen su justo lugar en la (re)construcción del Ecuador.

Aunque los palenques marcan una larga tradición popular dentro de la historia afro en las Américas, mucho de lo que la sociedad no afro sabe de los afroecuatorianos se debe al aporte literario de algunos intelectuales que se han dedicado a interpretar, cultivar y difundir la cultura afro. A pesar del recelo expresado arriba en cuanto a ciertos intelectuales no representativos del pueblo negro, las obras escritas por Nelson Estupiñán Bass, Adalberto Ortiz y Antonio Preciado, por ejemplo, demuestran que la literatura bien hecha y honesta sí puede jugar un papel importante dentro de lo que hoy se está refiriendo como el "Proceso de Comunidades Negras." No hay que olvidar que ambos textos que he comentado en este capítulo continuamente identifican la preservación y la enseñanza de las expresiones culturales como uno de los imperativos de los pueblos negros. Según el reporte del II Encuentro Afro Binacional:

La cultura afroecuatoriana no sólo comprende aspectos como la danza, música sino también otros como la religión y el pensamiento. Todos estos elementos son parte importante de la cultura para fortalecer el comportamiento y la conducta de la comunidad negra colombiana o afroecuatoriana. Este conjunto de elementos ayudan a manejar situaciones de conflicto y permiten participar del conocimiento de la tecnología de la otra cultura para poder combatirla. (6-7)

Y, más adelante, se vuelve a insistir que la cultura "Es la fuente de la que se debe construir y reconstruir los símbolos, signos, conceptos y estrategias del apalencamiento" (11). De modo que, la cultura funciona como un instrumento de unidad y de resistencia. Por una parte, deja constancia de las vivencias e intereses comunes que constituyen la díaspora; por otra parte, establece una identidad propia desde la cual los pueblos negros pueden definir el papel que piensan jugar en sus países respectivos.

En el caso del Ecuador, donde gran parte de la literatura escrita se caracteriza por su orientación social y reivindicativa, no sorprende que muchos de los principales escritores afroecuatorianos también hayan creado obras literarias en las cuales se complementan las exigencias estéticas con las éticas. De hecho, puesto que estos 
escritores siempre han sido conscientes de su doble función de artistas y ciudadanos, por una parte, y de los múltiples espacios en que siguen ejerciendo sus actividades (e.g., la literatura, el periodismo, la docencia, la política), por otra, es lógico considerarlos verdaderos trabajadores de la cultura. Entre ellos y el pueblo no ha habido barreras realmente infranqueables, y por lo tanto desde sus obras se percibe una fluidez que corre entre la cultura formal y la popular, entre la escritura y la oralidad, entre el arte y el compromiso social. En fin, las obras revelan que la creación de cada escritor destacable se ha hecho desde y en representación de su pueblo afroecuatoriano.

La interacción constante entre los escritores y el pueblo que acabo de resaltar corrobora la idea de que "los textos literarios y los no-literarios circulan inseparablemente" (Leitch 164; traducción mía). Por eso mi interés en asentar a continuación vínculos entre los textos examinados arriba y los que han aparecido en diversas revistas literarias publicadas a través del siglo XX. Mi preocupación como investigador cabe en lo que hoy se conoce como "la crítica cultural" (cultural criticism). A diferencia del análisis literario convencional, "la crítica cultural no sólo se fija en la literatura canónica, sino en toda una gama de artefactos, fenómenos y discursos supuestamente no-canónicos y no-estéticos" (Leitch 2; traducción mía). También, la estrategia que empleo coincide con la noción de que "las investigaciones y las valoraciones que se hacen sobre las viven- cias negras del Ecuador, como en cualquier otro lugar, exigen métodos integrados y creativos que crucen líneas disciplinarias para, así, tratar con seriedad la etnografía, la historia, la literatura y la riqueza cultural de la gente afrolatinoamericana de todas partes" (Whitten, Jr. y Quiroga 313; traducción mía).

Para los propósitos de mi análisis, he optado por concentrarme en algunas revistas culturales de Esmeraldas en vez de la literatura reconocida de algunos escritores ya estudiados por otros críticos. ${ }^{9}$ A diferencia de las obras literarias que generalmente son leídas como una expresión individual, las revistas nacen de proyectos más colectivos $y$, por consiguiente, se relacionan más claramente con movimientos populares como "El Proceso de Comunidades Negras." Al analizar algunas revistas culturales de Esmeraldas como una expresión pionera de "El Proceso de Comunidades Negras," se pone de relieve la naturaleza constante y evolutiva del actual movimiento. Además, al establecer una perspectiva histórica de la lucha del pueblo afroecuatoriano que desde hace mucho tiempo se está realizando en espacios paralelos y complementarios, se comprenderá mejor que "El Proceso de Comunidades Negras" no ha surgido de ningún vacío ni es el resultado de modas fugaces.

De hecho, ya desde 1905, en plena época turbulenta del liberalismo incipiente que abriría al Ecuador hacia la modernidad, se encuentra en El Luchador de Esmeraldas una conciencia de identidad, ora de provincia, ora de raza, fundamentada 
en condiciones sociales profundamente marcadas por la explotación y la injusticia frente al resto de la sociedad ecuatoriana. En un artículo intitulado, "Verdades amargas," se vislumbra una profunda frustración ya que los sacrificios y los méritos de los esmeraldeños no se reconocían:

La sangre de los esmeraldeños ha sido vertida donde quiera que se ha combatido por el triunfo de la causa liberal, y notorias y proverbiales han sido y son la constancia y la intrepidez con que siempre la han defendido; ¿y el premio a todas estas que podemos llamar virtudes públicas?... El olvido... el silencio... y hasta el desprecio. [I, 12 (1 diciembre 1905), 1]

A pesar de los casi cien años que han transcurrido desde la publicación de este texto, es fácil ver en su reclamo un antagonismo que servirá de semilla para la creación posterior de una política oposicional tan patente en lo que se escucha actualmente en la provincia.

Aunque no aparece en lo citado una referencia directa a lo racial, la realidad demográfica e histórica de la provincia es incuestionable $y$, consecuentemente, se puede entrever la tensión inherente a una identidad múltiple (ser esmeraldeño, negro y ecuatoriano) que el resto de la sociedad quisiera desconocer o desarticular. Es precisamente esta tensión la que estalla en un artículo publicado en 1929 en $\mathrm{El} \mathrm{Co}$ rreo, una revista cuyo lema era "Una Esmeraldas Mejor." El artículo que interesa aquí se titulaba, "El problema educacional en Esmeraldas." El antagonismo y la frustración tan patentes en El Luchador ahora se expresan con sátira, y esto sugiere un importante cambio discursivo. De un tono amargo de lamentación y de queja, se pasa a una voz de combate abierto y agresivo. Según se lee:

Para aquel que no nos concoce de cerca, Esmeraldas significa lo último, la cola de la República; un lugar donde no se puede vivir, porque las condiciones climatológicas hacen de él un infierno inhabitable; un lugar donde no se puede encontrar una sociedad con humos de civilizada [...]; una tierra en donde los habitantes—negros semisalvajes_andan vagando desnudos por las selvas. [I, 44 (8 junio 1929), 4]

El racismo contra los negros es el eje de los estereotipos que se denuncian aquí. Con un desarrollo lógico de ideas, el que escribe va desde lo más general (el problema de la marginación de la provincia) hasta lo más específico (la causa principal de dicho problema). Si bien es cierto que el clima tropical explica en parte lo inhóspito de la provincia, se entiende que es realmente la gente negra la que mantiene la provincia en un estado bárbaro debido a su supuesta falta de civilización. La caricatura despectiva al final del párrafo deja al descubierto toda una mentalidad colonialista que ha sabido justificar sus políticas opresivas mediante una negación rotunda de la humanidad de sus víctimas.

Pero, en este artículo, el escritor no se contenta con sólo denunciar los prejui- 
cios y la injusticia. Un aspecto central de su crítica es la deconstrucción del discurso racista que quisiera dividir a todo el mundo en dos campos-o en el de los bárbaros o en el de los civilizados. Es así que escribe:

Pero pasa que muchos hasta ignoran que entre las 17 provincias que forman el territorio de la nación ecuatoriana existe una que por ventura se llame Esmeraldas. Este mal se debe a la educación que se recibe en las escuelas-especialmente en la Sierra, donde la enseñanza de Geografía en 4to. grado se reduce al estudio del callejón interandino. (4-5)

Lo que más se destaca de los civilizados es su ignorancia, producto de un sistema de educación centralista que no conoce la magnitud de su territorio; por extensión, sus conceptos acerca de aquellos habitantes del país que viven más allá de su radio de experiencia han de ser defectuosos, cuando no completamente falaces. De manera que la imagen de los "negros semisalvajes [que] andan vagando desnudos por las selvas," revela más sobre los que manejan tales estereotipos que sobre los que son el objeto del desprecio.

El golpe de gracia de esta crítica que ha invertido el esquema sarmentino de "civilizados y bárbaros," se vislumbra al leer: "Verdad es que muchos somos tostados por el sol trópico, pero no somos todos negros, y los que lo somos, poseemos algo mejor en la cabeza [...]" (5). Frente a la visión simplista e ignorante de los que manejan el poder, el que escribe en $\mathrm{El} \mathrm{Co}$ rreo insiste en la complejidad de lo que significa ser negro y esmeraldeño, e implícitamente desafía todo un sistema sociocultural que todavía encuentra en los estereotipos su justificación para no tratar frontalmente los problemas apremiantes de la provincia y de los afroecuatorianos, en general.

Dos años más tarde en 1931, se publicó en El Correo otro artículo en el cual se siguió matizando el tema de la identidad como un fenómeno conflictivo. Con el título de "Intereses esmeraldeños," el articulista anónimo puntualizó:

Es muy lógico que [...] el interés nacional debe primar por sobre todos los demás intereses; por consiguiente, todas las actividades públicas y privadas [...] deben orientarse hacia aquel interés nacional [...]. Pero no es menos cierto, que la nacionalidad ecuatoriana no es una abstracción sino una realidad, y como tal se compondrá de realidades. La nación es una realidad de colectividades humanas integradas por individuos [...]. [III, 267 (15 agosto 1931), 6]

La distinción que se hace entre una nación abstracta y una compuesta de "realidades" parece anunciar un cuestionamiento conceptual que posteriormente será elaborado para ocupar el centro mismo del debate sobre la plurinacionalidad. Por supuesto, todavía en 1931 el debate no llegaba tan lejos; sin embargo, el juicio que estoy comentando revela ciertas fisuras en 
el pensamiento nacional de la época. Para los esmeraldeños, en particular, aún se trataba de reconciliar los intereses de la provincia con los de la nación:

[...] los esmeraldeños debemos tener como ideal inmediato, como tarea inaplazable que cumplir, el preocuparnos del porvenir de Esmeraldas [...]. Y ello sin miras particularistas $[\ldots]$, teniendo como ideal supremo hacer una Esmeraldas grande dentro de un Ecuador grande por su progreso moral y material. (6)

Con el tiempo, sin embargo, se comprendería que la esperanza de que pudiera haber una reconciliación de intereses era, más bien, una ilusión que solamente prolongaría el estado de dependencia en que se hallaba la provincia. De ahí surgiría una creciente radicalización de posiciones, especialmente en la medida en que iba a prevalecer la cuestión racial en la identidad esmeraldeña. En efecto, fue la concientización racial que convirtió la situación de Esmeraldas en un problema mayor que el de un mero asunto de regionalismo tan generalizado en las relaciones que el gobierno central tiene con otras provincias.

Naturalmente, la radicalización a que me refiero ha sido un proceso paulatino, y en no poca medida ha crecido muchas veces a partir de inquietudes y propuestas dispersas $y$, aparentemente, desconectadas. Las revistas ayudan a contextualizar este proceso puesto que ellas constituyen un archivo histórico y un testimonio vivo de los esfuerzos del sector intelectual por analizar la situación sociopolítica y socioeconómica esmeraldeña y por articular una identidad híbrida capaz de recoger sus componentes de provincia, de raza y de nación. Hasta aquí, en lo poco que he comentado de las revistas, se vislumbra un diálogo abierto en el cual se debate el destino de Esmeraldas (y desde Esmeraldas) al mismo tiempo que se buscan las vías apropiadas para realizarlo.

Con la publicación en 1935 de $\mathrm{Ma}$ rimba, el proceso de concientización siguió avanzando. El título mismo de la revista despertaba una alusión cultural que no se puede desprender de sus raíces raciales. En el primer número, Nelson Estupiñán Bass y Horacio Drouet, los directores de la revista, señalaron que Marimba era una "Revista trimestral (vialidad, agricultura, industrias, deportes, educación y literatura)" [I, 1 (agosto 1935), portada], y en base a esta descripción, se comprende la medida en que los intelectuales se disponían a asumir un papel multifacético en la sociedad. Así es el caso de Estupiñán Bass; él no solamente se ha establecido como uno de los mayores escritores del Ecuador y de la diáspora americana, sino que se ha distinguido como uno de los mayores defensores y promotores de la cultura y de los derechos del pueblo afroecuatoriano.

En la "Nota editorial" del número inaugural de la revista, salen a la luz varios temas que servirán de puente entre algunas inquietudes expresadas en el pasado y ciertas aspiraciones que posteriormente impulsarán "El Proceso de Comunidades Negras" de la actualidad. Lo primero que 
quisiera destacar es el doble discurso que caracteriza Marimba. Mientras que se abogaba en primer plano por las necesidades de la provincia como territorio ecuatoriano, había una estrategia soterrada para mantener viva la presencia afro de Esmeraldas, pero sin crear sospechas de ser una publicación separatista. Para el lector superficial, las referencias a lo afro trataban de un folklore inofensivo y hasta turístico visto, por ejemplo, en el título de la revista. Pero, para los lectores iniciados, los referentes culturales preparaban el terreno para otro tipo de discurso-el discurso afroecuatoriano.

En el capítulo sobre Juyungo traté el tema de la ambivalencia racial de Ortiz como una manifestación de las tensiones sociopolíticas y socioculturales de la época, y creo que los directores de Marimba también se vieron obligados a responder a las mismas circunstancias del momento, pero con mecanismos expresivos que no provocaran malentendidos o antagonismos en la sociedad ecuatoriana, en general. De hecho, en conversación con Estupiñán Bass, éste me manifestó que para él y sus compañeros el mayor peligro de los años 30 que afectaba a todos los ecuatorianos era el fascismo y, por lo tanto, en nombre de la solidaridad nacional e internacional se optó por suspender los reclamos raciales hasta después de la Segunda Guerra Mundial cuando retomaron la negritud como tema vital. ${ }^{10}$

De modo que a pesar de la vida fugaz de la revista, ${ }^{11}$ los directores de $\mathrm{Ma}$ - rimba supieron desarrollar un proyecto de reivindicación que acercaba lo afro y lo esmeraldeño, por un lado, y sentaba las bases para la futura unificación de lo afroesmeraldeño, por otro. Las necesidades de la provincia como tal son evidentes al leer:

Resulta, para nosotros, impostergable dar una exacta noción de la sección más norte del litoral ecuatoriano, ya que las elementales nociones geográficas que se tiene de Esmeraldas en nuestras propias latitudes están plagadas de errores, totalmente perjudiciales, a los que nos proponemos extirpar de raíz. [I, 1 (agosto 1935), 1]

Ante las referencias a la misma ignorancia general acerca de la provincia y sus habitantes, que ya habían aparecido en otras revistas de Esmeraldas, se hacía una llamada a la acción que debía ser educacional y política, a la vez:

Laboraremos porque se satisfagan las necesidades vitales de Esmeraldas, que intencionalmente han sido indefinidamente postergadas por todos los Gobiernos, haciendo que Esmeraldas permanezca en un recodo del progreso, negándole el avance que está no sólo en el derecho de recibir, sino también en el derecho de exigir. (1)

El tono combativo de dicha llamada surge con la denuncia de una política oficial del Estado que pretendía mantener Esmeraldas en la miseria. Además, al expresarse en términos de sus derechos de protestar y luchar, comienza a percibirse una politización de principios y actitudes. 
Aunque esta politización todavía no se identificaba abiertamente con un proyecto concientemente racial, el lector atento entendía que la negligencia del Estado se debía a la presencia afro en Esmeraldas. La protesta ganaba profundidad y sentido al leerla junto al poema de Arcelio Ramírez que se titulaba, "Negro," y que fue escrito especialmente para Marimba. En una estrofa se leía:

La Iglesia quiso esclavizarte para siempre; te habló de Cam y trazó un demonio con la epidermis tuya!

La democracia apenas intentó suavizar tu dolor. [I, 1 (agosto 1935), 18]

Y, en otra estrofa:

Negro!

tu porvenir está inédito!

Eres una reserva poderosa de la especie humana.

Tu sangre es la más pura que corre por venas de raza alguna. (19)

La publicación de este poema en este número de la revista no me parece una mera casualidad puesto que completó la denuncia de la "Nota editorial." Según se puede desprender de las dos estrofas citadas, Esmeraldas y el "Negro" eran víctimas de las instituciones oficiales del mismo sistema de poder (i.e., el Estado y la Iglesia) y de la misma democracia falsa; por consiguiente, ambos compartían una misma experiencia. Además, el "nosotros" de la llamada a la acción de la "Nota editorial" ("Laboraremos") tenía resonancia en el poema al afirmar: "Negro!/tu porvenir está inédito!” En efecto, para los lectores de la época, existía una relación estrecha entre Esmeraldas y el negro del poema, revelando una estrategia hábil de los directores de Marimba que he caracterizado como un doble discurso, y que radicaba en la yuxtaposición intencionada de un reclamo aparentemente no racial y la afirmación aparentemente benigna de lo afro. En otras palabras, la supuesta separación de Esmeraldas y lo afro satisfacía, por una parte, los imperativos oficiales de una nacionalidad que se definía como mestiza y en plena armonía racial, y por otra parte, cumplía con las exigencias inmediatas de un socialismo internacional que abogaba por la solidaridad de clase frente a sus enemigos comunes. Entretanto, mientras que se reconocía la necesidad de detener la articulación de un discurso abiertamente afroesmeraldeño, revistas esmeraldeñas como Marimba constituían un espacio desde el cual se podía equilibrar intereses adversos y mantener viva la herencia afro durante la espera.

Así fue el espíritu de Hélice, la revista oficial del grupo cultural esmeraldeño del mismo nombre que se fundó en 1949. ${ }^{12}$ Nelson Estupiñán Bass servía otra vez de director de revista, y el consejo de redacción incluía a otras figuras que también habían participado en Marimba. ${ }^{13}$ Me parece que la presencia de algunos de los mismos participantes en las dos revis- 
tas implica una continuidad de propósitos y objetivos, especialmente en lo que se refiere a la función del intelectual de Esmeraldas. El compromiso social del grupo y su revista se anunciaba desde su lema oficial: "Por una cultura al servicio del Pueblo" [V, 12 (enero 1956), en la portada]. Más concretamente, en un artículo intitulado, "Estatutos del Grupo Cultural Hélice," se explicaba:

Y es que siendo la situación de Esmeraldas verdaderamente distinta de las otras zonas de la República, con características acentuadas, que producen marcado contraste entre nuestra provincia y las demás, el espíritu del hombre esmeraldeño tiene que expresar esencialmente su signo peculiar. [...] Ante el sombrío panorama de una provincia que parece hubiera nacido bajo los auspicios de una estrella funesta [...], comprendemos que nuestra primera obligación estética es ubicarnos en geografía verde de Esmeraldas para levantar nuestra historia. [V, 12 (enero 1956), 39)

Es de notar que todavía parece haber una reticencia en cuanto a la presencia afro como el rasgo definitorio de la identidad esmeraldeña. Pero, de nuevo, la omisión es aparente. Conscientes del peso histórico del mestizaje como el carácter nacional (i.e., la ecuatorianidad vista en blanco e indio), los miembros de Hélice siguieron expresándose con un doble discurso, a veces sutil y a veces no tanto.

Según los estatutos citados, la razón de ser del grupo todavía consistía en protestar el atraso eterno de Esmeraldas, un proyecto común al de todas las provincias necesitadas. Estos defensores de los intereses esmeraldeños, sin embargo, comprendían su compromiso para con el pueblo más allá de la miseria y del estancamiento general de la provincia. Para ellos, Esmeraldas se caracterizaba por su situación "verdaderamente distinta," con "características acentuadas," y toda representación de dicha situación exigía el "signo peculiar" de la provincia. No cabe duda de que las referencias a la especificidad de la provincia emanaban de una profunda conciencia del ser afroesmeraldeño. Además, y de especial importancia para cualquier aprehensión cabal del aporte del intelectual afroecuatoriano, los estatutos del grupo Hélice establecieron como su modus operandi intelectual el trabajar ("obligación estética") desde lo afro, para así, "levantar nuestra historia."

Aunque la identidad afro todavía se expresaba a sotto voce, oblícuamente si se prefiere, en base a los materiales analizados hasta aquí, y debido a un efecto acumulativo de dichos materiales, se puede detectar entre los intelectuales una creciente ebullición de planteamientos e inquietudes que cobran su verdadera importancia cultural al leerse en el contexto de un futuro afrocentrismo abierto, combativo y del pueblo mismo de Esmeraldas.

Otra revista destacable dentro del proceso evolutivo de la creación y promoción de la identidad afro, ora en Esmeraldas ora en el resto del Ecuador, fue Tierra Verde, la publicación oficial del Núcleo de Esmeraldas de la Casa de la Cultura Ecuatoriana. Tierra Verde comenzó a publicarse en 1952, y así como con Marimbay Hé- 
lice, sobresale la participación de los mismos intelectuales de antes. Lo que distinguía Tierra Verde de otras revistas fue el auspicio de una importante institución cultural como la Casa de la Cultura Ecuatoriana; el prestigio institucional y los recursos, por más modestos que hubieran sido éstos, convirtieron Tierra Verdeen un vocero de la cultura nacional de no poca influencia en la provincia. ${ }^{14}$

Puesto que esta revista sobrevivió por varias décadas, se la puede considerar como un compendio del pensamiento intelectual de Esmeraldas que prevalecía entre 1952 y 1987. A pesar de algunos períodos en que la revista no se publicaba debido a problemas presupuestarios, la longevidad de Tierra Verde facilita una reconstrucción de las ideas pertinentes a la evolución de una identidad afro y esmeraldeña. El contenido del conjunto de números publicados se caracterizaba por una gran variedad de enfoques, perspectivas e interpretaciones acerca de dicha identidad. Internamente, parece que había una lucha por fijar los parámetros adecuados para un proyecto que oscilaba entre lo ecuatoriano y lo esmeraldeño, por no decir lo afro. César Névil Estupiñán, el primer director de Tierra Verde, resulta bastante problemático al respecto. En un sentido, su afán por incorporar a Esmeraldas en la nación ecuatoriana amenazó con diluir por completo cualquier posibilidad de expresar aquel "signo peculiar" de la provincia que apareció en los estatutos del Grupo Hélice, y que ya comenté. En un artículo de 1954, intitulado "Esmeraldas, tierra de libertad," César Névil Estupiñán escribió:
Por ser Esmeraldas una tierra auténticamente ecuatoriana, su vocación ha sido siempre, [...] la Justicia y la Libertad. El hombre de este lado del Ecuador ha vivido realmente apegado a estos nobles postulados que son orgullo de nuestra nacionalidad.

$[\ldots]$

Ya en la era republicana Esmeraldas fue siempre una antena sensible a todas las palpitaciones del vivir nacional. [II, 4 (agosto 1954), 2]

Y, en 1956, el mismo autor siguió afirmando en "Hay que enseñar a amar a Esmeraldas":

Esmeraldas, respondiendo a un anhelo tradicional, tiene que incorporarse urgentemente a la cultura nacional, vincularse estrechamente a ella y contribuir poderosamente a la creación de una cultura específicamente ecuatoriana. Esto es lo fundamental.

$[\ldots]$

Pero además y sobre todo, educamos aquí para el Ecuador; inculcamos en nuestros alumnos el amor fervoroso, encendido a nuestra Patria que siempre la deseamos digna, grande, elevada, unificada del uno al otro confín y fuerte [... ]. [III, 11-12 (marzo 1956), 3)]

Parece que tanta insistencia en Esmeraldas como una provincia "auténticamente ecuatoriana” es tautológica y confirma la medida en que el racismo ha condicionado la manera de pensar y de actuar 
tanto de los esmeraldeños como de los demás ecuatorianos. ¿Qué más podía ser Esmeraldas si no ecuatoriana? Lógicamente, la omnipresencia de lo afro convertía a la provincia en un territorio extraño que no cabía dentro del imaginario nacional oficial. ${ }^{15}$ Por eso, la retórica altisonante empleada por César Névil Estupiñán debe leerse como un intento de desmantelar toda una tradición de sospecha y de rechazo que ha creado la necesidad de justificar la legitimidad esmeraldeña frente al resto del país. La estrategia de exaltar lo nacional al mismo tiempo de no hacer ninguna referencia a lo afro, sin embargo, llevaba el riesgo de producir el efecto contrario. Es decir, el silencio ante lo afro podía haberse interpretado como un deseo de blanquearse, y como tal, la única legitimidad que se estaría estableciendo hubiera sido la del racismo.

Muy otro resultaba el mensaje del mismo César Névil Estupiñán, cuando él escribió en 1955, "Breve síntesis del paisaje y del hombre de Esmeraldas." El marcado contraste con el discurso nacional comentado arriba hace necesario reproducir in extenso selecciones de este nuevo texto:

Y así dicen unos que Esmeraldas es una tierra de negros. Por todas partes los hombres de color obscurecen la luminosidad maravillosa de la naturaleza y quiebran la plácida armonía del paisaje con la estridencia de sus risas. Los ojos de los negros tienen el fulgor de una audacia salvaje. Esmeraldas es tierra de negros, donde es absoluta la ausencia del blanco. Tierra que es verdadero infierno del trópico. [...] A Esmeraldas se puede venir para no salir con vida. [...] La provincia es una tierra bárbara, primitiva, $[\ldots]$. Por eso muchos [...] llegan a Esmeraldas, según creen ellos, a civilizar, porque los negros salvajes lo ignoran todo. Pero para esa obra civilizadora es preciso, afirman, llevar el arma lista, porque los negros macheteros están acostumbrados a comerse vivo a todo ser extraño que ven. [II, 9-10 (agosto 1955), 5]

Y, a continuación, seguía el autor afirmando:

Muchos nos echan en cara nuestra mulatería, nuestra zambería, nuestro negrismo. Pero, precisamente, en eso debe cimentarse nuestro orgullo. El negro ha sido siempre y en todas partes-pese a la esclavitud en que ha vivido y a la bárbara explotación de que ha sido víctima - un campo abonado para la prédica democrática y para la lucha contra la tiranía y el despotismo. Por eso los esmeraldeños hemos sido rebeldes y nos hemos lanzado contra la opresión. Lo han sido nuestros antepasados y nosotros debemos seguir siéndolo para ser honrada y lealmente esmeraldeños.

[...]

Los poetas, novelistas e intelectuales de la raza oprimida levantan valerosamente su voz para protestar contra la injusticia de que han sido víctimas los negros, los zambos y los mulatos. Y al hacerlo han incorporado a la literatura un nuevo motivo hoy en boga en la música, en la danza, en 
la pintura, en la escultura [... ]. La moda del negro, digamos mejor: de lo negro, se ha generalizado tanto que está inundando toda la vida de nuestros días. No sólo aquí en el Ecuador, sino en muchos de los países a los que nosotros acostumbramos a considerar como civilizados. (20)

No cabía confusión ninguna con la actitud frontal de este texto. Esmeraldas era y es una provincia afro, y la defensa que se hacía de la provincia en lo citado ya no se basaba en una ecuatorianidad idealizada, una que se consideraba imprescindible para la supuesta legitimidad de la provincia. Ahora, más bien, se atribuía la grandeza de Esmeraldas ("su vocación por la Justicia y la Libertad") a su negritud, y más concretamente aún, a su experiencia colectiva de la esclavitud. En efecto, aquí César Névil Estupiñán dejaba a un lado el discurso de un patriotismo trillado para remontarse a la verdadera historia afroecuatoriana, y así terminó subvirtiendo los estereotipos que él había ridiculizado en el primer párrafo de arriba. Mediante la (re)apropiación de conocidos símbolos racistas, el autor liberó a su "tierra de negros" del oprobio de ser un "verdadero infierno del trópico," y la exaltó como "un campo abonado para la prédica democrática...."

Para el lector atento de la época, para el que acostumbraba interpretar el lenguaje del doble sentido como una forma tradicional del cimarronaje, el discurso irónico de César Névil Estupiñán cumplía su función de reivindicación. Se comprendía que la única "obra civilizadora" era la de los herederos de los esclavos, y en ese contexto, se reconocía la misión del intelectual que estaba en condiciones de promocionar lo afro (i.e., hacerlo conocer, legitimarlo según sus propios méritos) en todas partes. Pero, huelga insistir que el tipo de promoción que las palabras de César Névil Estupiñán pedían no se leía desde ningún pasado utópico y perdido. Lo afro tenía que comprenderse desde la experiencia misma de la negritud, y en ese sentido, concientemente o no, César Névil Estupiñán ya anunciaba "la actitud de apalencarse" que sirve de piedra angular en el actual "Proceso de Comunidades Negras."

Aunque los tres textos de César Névil Estupiñán que acabo de analizar podrían sugerir alguna vacilación de principios y de estrategias discursivas debido a una aparente contradicción entre los planteamientos publicados en 1955 y los que aparecieron en 1954 y 1956, creo que es necesario no perder de vista que el movimiento afro a través de toda la diáspora sigue siendo un proceso. Por lo tanto, una lectura de los materiales seleccionados ayuda a trazar históricamente dicho movimiento.

También, es importante señalar que la perspectiva afro de César Névil Estupiñán, y la de muchos de sus contemporáneos, no se expresaba con un afán separatista. Esmeraldas, y todo lo que la provincia implicaba, eran el Ecuador. Pero, pese a cierta tendencia de evocar el esencialismo de la raza cósmica de Vasconcelos, César Névil Estupiñán quiso enfrentar la di- 
versidad de su provincia y, por extensión, la del Ecuador. El resultado de su "Breve síntesis del paisaje y del hombre de Esmeraldas" fue, entonces, una superación del concepto homogeneizador del mestizaje nacional como una fusión de las razas. Ya desde 1955, César Névil Estupiñán escribía en términos de lo híbrido, poniendo de relieve un pluralismo dinámico que celebraba la co-participación de diversos sectores del conjunto nacional. ${ }^{16}$ Según él explicaba:

[...] en el torbellino étnico de nuestra tierra esmeraldeña, surgieron como resultantes híbridos: el zambo y el mulato con un pensar y un sentir pujantes. Trayendo una nueva emoción y una nueva actitud para mirar el ancho panorama del mundo. Este hibridismo trajo también una vigorosa insurgencia para luchar contra la opresión que había esclavizado y menospreciado y sumido en la miseria a sus obscuros antepasados y que aún trataba de emplear idénticos sistemas con ellos. (20)

De esta manera, en el artículo de 1955, se comprendía que la liberación definitiva del pueblo afro no se iba a encontrar en el mestizaje tradicional, sino en lo que hoy se acostumbra llamar la plurinacionalidad. Por supuesto, para que esta plurinacionalidad sea una verdadera democratización, será imprescindible que se cultive en el país una nueva mentalidad que comprenda que el futuro del Ecuador depende de la participación activa, y hasta protagónica, de los afroecuatorianos.

$\mathrm{Al}$ interpretar el concepto de lo híbrido de César Névil Estupiñán como una expresión incipiente de la plurinacionalidad ecuatoriana, por una parte, y como una afirmación enérgica del papel medular que siguen jugando los afroecuatorianos en la democratización del país, por otra, los vínculos entre una revista cultural como Tierra Verde y el actual "Proceso de Comunidades Negras" se hacen evidentes. Además, entre los múltiples materiales publicados en Tierra Verde, se descubre una identificación étnica profundamente transnacional que acercaba a los pueblos de Esmeraldas y del Chocó de Colombia. Es decir, la iniciativa actual de crear la Comarca Afropacífica parece representar una culminación de un amplio proyecto afrocéntrico cuyas raíces han entrelazado a varios sectores de los pueblos afro desde hace tiempo. Es así que Juan Checa Drouet había constatado lo siguiente en un artículo de 1956 intitulado, "La fraternidad de los pueblos ecuatoriano-colombiano en la provincia de Esmeraldas":

Mas en donde palpita [...] con más entusiasmo $[\ldots]$ esta tradicional fraternidad de los pueblos colombiano-ecuatoriano, es en la provincia de Esmeraldas.

\section{[...]}

Los esmeraldeños prácticamente carecen de frontera natural con Nariño y en general con la región colombiana del río Mira, que baña ambos países. Tampoco existe la frontera humana. [...] La raza es la misma, mestiza, un poco recargada de pigmentos, al punto que no hay familia esmeraldeña que no tenga sus ancestros, la- 
zos familiares en Colombia. Su folklore es igual. La marimba esmeraldeña no es sino la misma marimba de Tumaco y Barbacoas. Lo mismo ocurre con sus canciones, sus bailes, sus aires populares. [...] Pero también los bambucos, el torbellino, el berejú, participan del calor y color tropical de la selva [...]. La negra y el negro enardecidos, presas de epilepsia, hacen una verdadera creación del baile afro-cubano. [III, 11-12 (marzo 1956), 1]

Si bien es cierto que las observaciones de Juan Checa Drouet no salían de un marco puramente folklórico, y como tales distaban mucho de las propuestas políticas expuestas en el II Encuentro Afro Binacional de 1997, es también cierto que mantenían abiertas las fronteras para que más tarde hubiera una solidaridad de lucha por los intereses comunes de los pueblos de la Comarca Afropacífica.

En 1980 salió a la luz Meridiano Negro, una nueva revista cultural que pretendió democratizar las relaciones entre el pueblo y los que tradicionalmente producían semejantes publicaciones. ${ }^{17}$ Aunque muchos de los mismos temas que ya he resaltado aparecieron en Meridiano Negro, esta revista anunció una nueva etapa en la articulación de la identidad afroecuatoriana. De hecho, en la portada misma del primer número, se identificaba Meridiano Negro como "una revista cultural para los afroecuatorianos" (agosto 1980). Curiosamente, en el segundo número se modificó la descripción, expresándola como "una revista cultural de los afroecuatorianos" (octubre 1980), 18 un cambio que comentaré más adelante.
El uso del término "afroecuatoriano" de por sí señalaba un cambio de actitud. A diferencia de la notable tendencia en las revistas anteriores de suavizar las referencias a lo negro, en Meridiano Negrose proclamaba abiertamente lo afroecuatoriano como lo esencial de su identidad $y$, también, como su estandarte de lucha. Indudablemente, el hecho de haberse publicado en Guayaquil contribuyó a ampliar los parámetros del proyecto afro en el Ecuador. Al salir de Esmeraldas, lo afro ya no podía seguirse definiendo estrictamente como una cuestión de una sola provincia. Es decir, aunque Esmeraldas continuaba sirviendo como la matriz cultural de los negros del Ecuador, por lo menos en el sentido de sus orígenes, el crecimiento de su realidad demográfica exigía nuevos referentes. La insistencia en lo afroecuatoriano, entonces, comunicaba dos cambios primordiales de perspectiva. En primer lugar, los movimientos migratorios hacia centros urbanos como Guayaquil en la Costa y Quito en la Sierra pusieron de relieve la presencia nacional de los negros; y, simultáneamente, desapareció toda vacilación en cuanto a reconocer que la raza constituiría el corazón mismo de cualquier proyecto de reivindicación o de liberación. Por eso, en la "Nota del director" del primer número de Meridiano Negro se declaraba:

Toda vez que por el Ecuador pasa un meridiano de la negritud universal, hecho innegable por la existencia de densas y crecientes comunidades negras en varias provincias del país-consideramos con- 
veniente relievar nuestro pigmento, mediante la publicación de este órgano que hoy sale a la luz pública, seguro de aglutinar todas las voces negras de la Patria, y de convertirse, por lo tanto, en el auténtico pregón de este gran segmento marginado y aplastado, de nuestra nacionalidad, hasta hoy sin voz ni voto en las grandes decisiones nacionales. [I, 1 (agosto 1980), 6]

Dentro de la nueva configuración de la nación y la raza que Meridiano Negro adoptó al examinar la situacion de los negros, surgió también el reconocimiento del pueblo afroecuatoriano como el actor central de su lucha de liberación. Así interpreto el cambio de la preposición empleada en la descripción de la revista que ya anoté arriba. Por lo menos en un sentido simbólico, el pasar de ser una revista "para" los afroecuatorianos a una "de" los afroecuatorianos sugiere una nueva dinámica de relaciones y comportamientos que, posteriormente, florecerá plenamente con la política comunitaria de "El Proceso de las Comunidades Negras." En cuanto a Meridiano Negro, concretamente, el cambio al "de" señalaba un espíritu de comunidad cimentado en la participación activa de todos $\mathrm{y}$, por lo tanto, se comprendía que la revista era "de" todos porque todos la hicieron una realidad, directa o indirectamente.

En los dos números de Meridiano Negro, la presencia del pueblo se manifestaba de múltiples maneras: a través de fotografías, de entrevistas, del contenido de los reportajes, y de las contribuciones de individuos no considerados intelectuales, propiamente. En efecto, Meridiano Negro representó un avance en lo que respectaba a la publicación de una revista cultural porque logró comunicar el sentido colectivo del pueblo afroecuatoriano al mismo tiempo que pretendió borrar las barreras sociales de clase que impedían la solidaridad. La importancia de haber un frente único se planteó en la "Nota del director" del segundo número de la revista: “Todo negro debe comprender que sólo cuando constituyamos una sólida unidad inexpugnable, podremos estar en capacidad de exigir a los gobiernos la solución de nuestros problemas específicos" (6).

Aunque Nelson Estupiñán Bass fue el director de Meridiano Negro, su prestigio de intelectual no opacó la presencia del pueblo en la revista. De hecho, la preponderancia de voces no intelectuales de los dos números creó un diálogo democrático en el cual se valoraba la experiencia vivida de cada persona como una legítima base de autoridad. Por eso, junto a los comentarios de Estupiñán Bass, se publicaban los de Betty Charcopo, una esmeraldeña radicada en el "Cristo del Consuelo," uno de los barrios marginados de Guayaquil. En una entrevista publicada en Meridiano Negro, la joven tuvo la oportunidad de hacer sentir su presencia vital en la lucha afroecuatoriana. Según explicaba:

Creo que por algo se define la raza negra, por ser fuertes, que jamás nos sentimos vencidos ante cualquier problema o circunstancia en la cual nos encontramos. 
Siempre se mantiene ese optimismo vigoroso de parte de los negros; siempre estamos en constante lucha para lograr nuestros objetivos. [I, 1 (agosto 1980), 5]

$\mathrm{Y}$, más adelante, la joven continuó afirmando:

$\mathrm{Y}$ a todos los negros que se sienten acomplejados por su color, que no sigan sometidos en la ignorancia, que el ser negro simboliza fuerza y dinamismo de lucha. Yo me siento orgullosa de llevar la piel negra. Pido a los esmeraldeños donde éstos se encuentren que de una u otra manera hagan algo por sacarla del estado de postración en que se encuentra ya que nosotros debemos siempre hacer resaltar los valores de nuestra raza. (18)

Por el tono positivo e instruido con que se expresaba Betty Charcopo, es fácil imaginarla como una futura dirigente del pueblo afroecuatoriano. Al recordar que su voz ha sido solamente una de muchas, y que Meridiano Negro se había identificado como una revista "de" los afroecuatorianos, uno aprecia mejor el verdadero significado histórico de esta publicación. Definitivamente, por haberle devuelto al pueblo el uso de la palabra en un foro igualitario y de respeto mutuo, Meridiano Negro logró comprobar que, a pesar de tantos años de explotación y de discriminación, los afroecuatorianos todavía conservaban la esencia misma de su tradición de los palenques. En fin, "el afro-ecuatoriano nunca se doblegó" [I, 1 (agosto 1980), 3].

Sería una ingenuidad, sin embargo, si se considerara el triunfo de Meridiano
Negro como algo más que un brevísimo momento de aliento y de esperanza en la lucha continua del pueblo afroecuatoriano por consolidar su justo lugar en el Ecuador. Para no perder de vista el drama que el pueblo afroecuatoriano sigue viviendo, vale hacer referencia a un discurso que se había pronunciado en el "Seminario de Música Autóctona” de 1987 y que se publicó en Tierra Verde. ${ }^{19}$ Según el expositor, Orlando Tenorio, algunas de las inquietudes que motivaron su intervención eran, a saber:

[...] inquietar a estudiantes, profesores e instituciones, para que se interesen por conocer, estudiar, practicar y defender nuestro folclor y música autóctona esmeraldeña, que en los actuales momentos está a punto de desaparecer por el quemeimportismo de los esmeraldeños mismos. [2a época, IV (1987), 49]

[...] sé que la realidad actual de la música y danza, es un problema sumamente serio y alarmante en Esmeraldas, conciente o inconcientemente, estamos desde ya asistiendo al entierro de nuestra identidad cultural. (49)

[...] se está aprendiendo a olvidar y muy equivocadamente por cierto, se quiere ignorar nuestras raíces étnicas, nuestro ancestro que es de origen africano y el término negro refiriéndose al ser humano se lo quiere reemplazar con moreno, como queriendo suavizar la expresión, en definitiva se siente vergüenza de ser negro. (50)

[...] ¿Cómo es posible que en esta América de indios, mulatos y negros, se busque 
sangre azul? Esta América es de flauta, rondador, bombo y marimba y en lo que concierne a Esmeraldas, esta tierra es de negros de origen africano y su música autóctona es el chigualo, el arrullo, el alabao y la marimba; gústele o no le guste a algún esmeraldeño desubicado del tiempo y de la historia. Quien cometa el error de negar la tradición, niega su ancestro y su origen. (50)

Estos fragmentos del discurso de Orlando Tenorio se ofrecieron como una voz de alerta ya que el abandono de la música esmeraldeña abordaba un problema mayor. El asedio cultural ha sido (y sigue siendo) general, atacando todos los aspectos de la vida del pueblo afroecuatoriano. Además, se desprende de las aseveraciones de Tenorio la idea de que la raza no se ha de definir como un fenómeno meramente fenotípico, del color de la piel, sino que supone toda una historia cultural y étnica que requiere de parte de los afroecuatorianos el estudio y el cultivo constantes. En otras palabras, ser negro es asumir la responsabilidad de serlo.

\section{Conclusión}

Las fuerzas del poder tradicional siguen aferrándose a aquel mestizaje tergiversado que se ha empleado para confundir un proyecto nacional sincrético y pluralista con uno que tiene sus bases ideológicas en una engañosa síntesis y unión monolítica. Como he indicado ya tantas veces en este libro, el mestizaje que celebra la supuesta fusión de razas y etnias en vez de la coexistencia de las diferencias nacionales se presta a políticas y a conductas opresivas y represivas. Así lo entienden los defensores de lo afroecuatoriano, por no mencionar a otros grupos afectados.

En nombre de un falso mestizaje nacional, se han negado e ignorado los intereses y las necesidades particulares de diversos sectores del país; también, en nombre de un falso mestizaje nacional, se ha negado la existencia nociva de un racismo que ha penetrado todos los niveles de la sociedad. En lo público, esta negación suele producir la injusticia, mientras que en lo personal suele hundir la identidad en un estado de enajenación. Naturalmente, resaltar lo racial como una causa primordial de las múltiples manifestaciones de la injusticia y la enajenacion no debe leerse como una negación de otras causas. Esto sería otra simplificación. Más bien, la insistencia en la centralidad de la raza como una vía efectiva de análisis promete llevarnos a nuevas perspectivas y a nuevas sensibilidades. Por eso, el crítico literario, Richard Jackson, ha enseñado que la lectura misma de las letras afrohispanoamericanas "exige que los lectores se abran a múltiples interpretaciones y perspectivas ante la realidad" (Black Writers and the Hispanic Canon 1).

De manera que tanto para los dirigentes del "Proceso de Comunidades $\mathrm{Ne}$ gras" como para los de las revistas culturales estudiadas en este capítulo, no puede haber una verdadera liberación sin la supervivencia de la raza. Tanto la urgencia como la vigencia de este imperativo se ha- 
cen clarísimas al leer las revistas en el contexto de la Comarca Afropacífica. Al mismo tiempo, mientras mejor se conoce el material de estas revistas culturales, mejor se comprende que el "Proceso de Comunidades Negras" constituye un verdadero proceso dinámico que es consecuencia de muchas contribuciones realizadas por diversos sectores del pueblo afroecuatoriano a través de la historia. Finalmente, por haber examinado juntas estas dos expresiones complementarias de la historia afroecuatoriana, uno se da cuenta de la medida en que "El Proceso de Comunidades Negras" pretende amalgamar los logros de los proyectos del pasado para, así, superarlos en el camino hacia la liberación definitiva.

\section{Notas}

1 Véase Black Literature and Humanism in Latin America; la traducción al español sería: "A diferencia de los héroes empleados por escritores blancos para simbolizar a la nación, la religión o la cultura nacional, los verdaderos héroes negros de hoy son ídolos de los negros porque, como los héroes del cimarronaje de antaño, ellos representan una insistencia heroica en sus propios valores sociales en vez de los de otra gente" (40; traducción mía).

2 Juan García Salazar se identifica como "un trabajador de la cultura negra." El "representa al pueblo negro de las provincias de Imbabura, Carchi y Esmeraldas, además de organizaciones urbanas, algunas de ellas en Guayaquil" (Samaniego Ponce 9A).

3 Entre las referencias bibliográficas que examinan las distinciones comentadas, véase Molefi Kete Asante, The Afrocentric Idea, Philadelphia: Temple University Press, 1987.
4 Quisiera agradecerle a Luis Zúñiga, co-representante del American Friends Service Committee de la zona andina, quien me proporcionó fotocopias de este texto y del reporte del "II Encuentro Afro Binacional Colombo-Ecuatoriano" que se celebró desde el 30 de mayo hasta el 1ro. de junio de 1997 en San Lorenzo, Esmeraldas. Este último texto será la base de mis comentarios sobre el rol que la diáspora está jugando en la construcción de una nueva identidad afroecuatoriana.

5 Pertinente a mi análisis es el comentario que hizo Leslie B. Rout, Jr. en su The African Experience in Spanish America. Según Rout, muchos negros de la provincia de Esmeraldas creían que la negligencia y la falta de atención del gobierno central (especialmente hasta comenzar la construcción del ferrocarril en los últimos años de la década de 1950), se debían al hecho de ser Esmeraldas mayoritariamente negra (234; traducción mía).

6 El tema de la territorialidad también aparece en el movimiento indígena como uno de los reclamos básicos de la plurinacionalidad. En este sentido, las aspiraciones del pueblo negro han de comprenderse como una parte integral de un amplio movimiento democrático y popular.

$7 \quad$ Este mensaje es pertinente al problema de las incursiones del neoliberalismo y la globalización en las relaciones entre el llamado Tercer Mundo y los países post-industrializados. Frente a la tentación de incorporarse al mundo global, hay el peligro de parte de países como el Ecuador de olvidarse de la relación estrecha que existe entre globalización y neocolonialismo.

8 Esta interpretación no ha de sugerir una renuncia de la importancia de Africa en la historia de los afroamericanos de todo el continente. La relación que se está haciendo entre el palenque y Africa representa una rearticulación (y no un rechazo) de símbolos y estrategias en la lucha por la libertad y la justicia. 


\section{Coda final}

9 Agradezco a la Universidad de Tennessee por el auspicio que me permitió realizar la investigación de las revistas en el Ecuador entre junio y agosto del 1997. Las revistas esmeraldeñas que pude localizar fueron El Luchador (1905), El Correo (1929), Marimba (1935), Hélice (1952), Tierra Verde (1952) y Meridiano Negro (1980). Aunque Meridiano Negro se publicó en Guayaquil en vez de en Esmeraldas, la considero una creación esmeraldeña puesto que los participantes en su mayoría eran esmeraldeños que vivían en Guayaquil. Si bien no pretendo ser exhaustivo con mi selección de materiales, creo haber recogido una muestra representativa de las revistas culturales esmeraldeñas publicadas a través del siglo XX.

10 Tuve esta conversación con Estupiñán Bass en su casa en Quito, el 10 de julio de 1997.

11 En general, el destino de la gran mayoría de revistas culturales del Ecuador ha sido (y sigue siendo) fugaz. Localicé los primeros dos números de Marimba, y tengo por entendido que no se publicó más.

12 Según Enrique Capurro, en un artículo intitu- lado, "Situación actual de la cultura en Esmeraldas," el Grupo Cultural Hélice era "la primera agrupación cultural conocida" en Esmeraldas. Otros grupos que Capurro mencionó eran: el Grupo Cultural Vértice (1955), el Grupo Cultural Somos (1959) y el Grupo Cultural Rumbo al Pueblo (1969). [Véase Meridiano Negro, I, 1 (agosto 1980), 11]

13 Durante mi investigación, sólo localicé dos números de Hélice. III, 7-9 (septiembre 1952) y V, 12 (enero 1956). Estupiñán aparecía como director en el número de 1952; en el de 1956, el director era Maximiliano Haas.

14 Aunque Hélice también recibió fondos de la Casa de la Cultura Ecuatoriana en la misma época, esta revista nunca fue la publicación oficial de la institución. En efecto, el Grupo Cultural Hélice y su revista se consideraron un proyecto entre muchos que merecía el apoyo de la Casa de la Cultura Ecuatoriana.

15 Es necesario recordar que no todos los esmeraldeños han sido (son) negros, y según el color de la piel, habría muchos "negros" que en- 
contraban en la retórica nacional un mecanismo de blanqueamiento (o, si prefiere, de ecuatorianización) tanto a nivel individual como a nivel de provincia.

16 Es de notar que el concepto de la hibridez que manejaba César Névil Estupiñán se adelantaba al pensamiento posterior del poscolonialismo de tales figuras como Homi Bhabha y Nelson García Canclini, por ejemplo.

17 Ya me referí a esta revista en el capítulo sobre Juyungo, destacándola como una publicación representativa de la diáspora afroamericana.

18 Tengo por entendido que solamente salieron los dos números de 1980.

19 El número de Tierra Verde a que me refiero pertenece a la segunda época de la revista; el presidente del Núcleo era Tomás Rueda Chaux. 


\section{Obras citadas}

Al referirse al etnógrafo francés Marcel Mauss, James Clifford observó que "si cada 'hecho' es susceptible a múltiples interpretaciones, teniendo sentido en diversos contextos e implicando en su comprensión el conjunto 'total' de las relaciones que constituye la sociedad estudiada, entonces esta premisa puede servir de estímulo para aprehender dicho conjunto mientras que se concentra en una de sus partes" (63; traducción mía). Aunque habrá algunos lectores que quisieran ver en lo afroecuatoriano un tema aislado y de mínima importancia en lo que respecta a un Ecuador mestizo y andino, Lo afro y la plurinacionalidad: el caso ecuatoriano visto desde su literatura fue impulsado por la misma orientación múltiple/simultánea/entrelazada que Clifford ha destacado. Lo afro-lo indígena-lo nacionallo plurinacional- lo andino-lo latinoamericano son, a la vez, muchos temas y uno solo. De hecho, el material analizado y comentado en este libro constituye en no poca medida un cuestionamiento de la llamada globalización del fin del milenio, una globalización económica que a menudo ofrece paradigmas culturales de homogeneización en un mundo hondamente heterogéneo. Y, de nuevo, uno se encuentra inmerso en la problemática del colonialismo de siempre, o cuando menos, en el nacionalismo que quisiera borrar las diferencias en nombre de una armonía y unidad nacionales más inventadas que reales. Sin duda alguna, lo afroecuatoriano como tema de análisis apunta a todo esto y pone de relieve la urgencia de cultivar vivencias que son, por antonomasia, simultáneamente propias y universales. 
Anderson, Benedict

1991 Imagined Communities: Reflections on the Origin and Spread of Nationalism. London: Verso.

Aguilera Malta, Demetrio

1959 "Dientes blancos," Trilogía ecuatoriana. México: Ediciones de Andrea.

1967 Infierno negro. México: Universidad Veracruzana.

Alexander Rodríguez, Linda

1985 The Search for Public Policy: Regional Politics and Government Finances in Ecuador, 1830-1940. Berkeley: University of California Press.

Appiah, Kwame Anthony

1992 In My Father's House: Africa in the Philosophy of Culture. New York: Oxford University Press.

Asante, Molefi Kete

1987 The Afrocentric Idea. Philadelphia: Temple University Press.

Ashcroft, Bill, Gareth Griffiths, Helen Tiffin

1989 The Empire Writes Back (Theory and Practice in Post-Colonial Literatures). London: Routledge.

Ayala, Enrique con Rodrigo de la Cruz

1992 et al. Pueblos indios, estado y derecho. Quito: Corporación Editora Nacional.

Balseca Franco, Fernando

1986 "Tambores de novela fuerte para la mala lectura de canciones perdidas," Crónica del Río (septiembre-octubre), 45-49.

Benítez-Rojo, Antonio.

1996 The Repeating Island: The Caribbean and the Postmodern Perspective, 2nd ed., trans. James 
Berron, Linda. Ed.

E. Maraniss. Durham: Duke University Press.

1995 ¿Feminismo en Costa Rica? Testimonios, reflexiones, ensayos. San José: Editorial Mujeres.

Bhabha, Homi.

1994 The Location of Culture. New York: Routledge.

1990 Ed. Nation and Narration. New York: Routledge.

Calderón Chico, Carlos

1990 "Conversación con Jorge Velasco Mackenzie,” El Telégrafo (22 marzo), $4 \mathrm{~B}$.

1991 Tres maestros. Guayaquil: Editorial Casa de la Cultura Ecuatoriana.

Castillo, Debra A.

1992 Talking Back: Toward a Latin American Feminist Literary Criticism. Ithaca: Cornell University Press.

Chanady, Amaryll, Ed.

1994 Latin American Identity and Constructions of Difference. Minneapolis: University of Minnesota Press.

Chávez Franco, Modesto

1944 Crónicas del Guayaquil Antiguo. 2a. ed. 2 tomos. Guayaquil: Imprenta y Talleres Municipales.

Clifford, James

1988 The Predicament of Culture:

Twentieth-Century Ethnography, Literature, and Art. Cambridge: Harvard University Press.

Chiriboga, Argentin

1994 Jonatás y Manuela. Quito: Abrapalabra Editores.
Coba, Carlos Alberto

1980 Literatura popular afroecuatoriana. Otavalo: Instituto Otavaleño de Antropología.

s/f Collective Memory: The African Presence in Latin America (A Study Guide on the Maroon Community of Esmeraldas, Ecuador). Washington, DC: Network of Educators on the Americas.

Collins, Patricia Hill

1991 Black Feminist Thought (Knowledge, Consciousness, and the Politics of Empowerment). New York: Routledge.

Cornejo, Justino

1973-74 Los que tenemos de mandinga (Prohibida para negros, zambos, mulatos y otros de igual ralea). Portoviejo: sin editorial.

Cornejo Polar, Antonio

1995 "Condición migrante e intertextualidad multicultural: el caso de Arguedas," Revista de Crítica Literaria Latinoamericana, 42 ( $2^{\mathrm{O}}$ semestre), 101-109. 
Costales, Piedad y Alfredo Costales

1990 "Completando la historia nacional, Ambrosio Mondongo rebelde del Chota," en Rafael Savoia, ed. El negro en la historia: Aportes para el conocimiento de las raíces en América Latina. Cayambe: Centro Cultural AfroEcuatoriano.

Cyrus, Stanley A.

1982 "Ethnic Ambivalence and AfroHispanic Novelists," Afro Hispanic Review, I, 1 (January), 29-32.

De Costa, Miriam. Ed.

1977 Blacks in Hispanic Literature (Critical Essays). New York: Kennikat Press Corp.

de la Cuadra, José.

1937 El montuvio ecuatoriano (Ensayo de presentación). Buenos Aires: Ediciones Imán.

1951 Los monos enloquecidos. Quito: Editorial Casa de la Cultura Ecuatoriana.

1984 Los Sangurimas. Quito: Editorial El Conejo.

Depestre, René

1985 Buenos días y adiós a la negritud. La Habana: Casa de las Américas.

Douglas, Frederick

1982 Narrative of the Life of Frederick Douglas, an American Slave. New York: Penguin Books.

DuBois, W.E.B.

1989 The Souls of Black Folk. New York: Bantam Books.

Egüez, Iván

1990

"El mestizaje y la novela histórica del Ecuador" (inédito). "Entrevista con Antonio Preciado," Letras del Ecuador, 174 (septiembre-noviembre), 24-28.

Espinosa Apolo, Manuel.

1995 Los mestizos ecuatorianos y las señas de identidad cultural. 2a. ed. Quito: Tramasocial Editorial.

Estrella, Santiago

1990 "Entrevista con Antonio Preciado," en Letras del Ecuador, 174 (septiembre-noviembre), 24-28.

Estupiñán Bass, Nelson.

1990 Cuando los guayacanes florecian. Quito: Libresa.

1992 Desde un balcón volado. Quito: Banco Central del Ecuador.

1994 Este largo camino. Quito: Banco Central del Ecuador.

Fama, Antonio

1977 Realismo mágico en la narrativa de Aguilera Malta. Madrid: Playor, S.A.

Fanon, Frantz. Piel negra, máscaras blancas. La Habana: Instituto del Libro, 1968.

Gallegos Lara, Joaquín

1981 Las cruces sobre el agua, en Obras escogidas. Guayaquil: Casa de la Cultura Ecuatoriana.

1987 "Raza, poesía y novela de Adalberto Ortiz," en Alejandro Guerra Cáceres, ed. Páginas olvidadas de Joaquín Gallegos Lara. Guayaquil: Editorial de la Universidad de Guayaquil.

Garay Arellano, Ezio

1988 "La élite económica de los negros en Guayaquil de 1742 a 1765," en Rafael Savoia. Actas del Primer Congreso de Historia del Negro en el Ecuador y Sur de Colombia. Quito: Centro Cultural Afro-Ecuatoriano. 
1988 "Los negros en Guayaquil en 1850," en Rafael Savoia. Actas del Primer Congreso de Historia del negro en el Ecuador y Sur de Colombia. Quito: Centro Cultural Afro-Ecuatoriano.

García, Juan

1988 Cuentos y décimas afro-esmeraldeñas. $2^{\mathrm{a}}$ ed. Quito: Ediciones ABYA-YALA.

García Canclini, Néstor

1995 "Narrar la multiculturalidad," Revista de Crítica Literaria Latinoamericana, $\mathrm{xxi}, 42\left(2^{\mathrm{O}}\right.$ semestre), 9-20.

Gates, Jr., Henry Louis

1988 The Signifying Monkey: A Theory of Afro-American Literary Criticism. New York: Oxford University Press.

Gil Gilbert, Enrique

1993 Yunga. Santiago de Chile: Editora Zig Zag, 1933. Gilroy, Paul. The Black Atlantic: Modernity and Double Consciousness. Cambridge: Harvard University Press.

Guillén, Nicolás

1990 Summa poética. Ed., Luis Iñigo Madrigal, 7 ed. Madrid: Ediciones Cátedra.

Handelsman, Michael

1995 "Baldomera y la tra(d)ición del orden patriarcal," Inti, 40-41 (otoño 1994-primavera), 195205.

1998 "Las contradicciones ineludibles del 'no-racismo' ecuatoriano: A propósito de Juyungo y la diáspora afroamericana," Chasqui, 27, 1 (mayo), 79-91.

1997 "Lo afro, la costa y la plurina- cionalidad del Ecuador," Afro Hispanic Review (Spring), 1624.

1994 "Recuperando una canción dos veces perdida: Un análisis afrocéntrico de Tambores para una canción perdida de Jorge Velasco MacKenzie," Revista de Estudios Colombianos y Latinoamericanos, 12-13, 13-17.

1997 "Trapped Between Civilization and Barbarity: An Analysis of José de la Cuadra's 'The Tigress," Latin American Perspectives, 29, 4 (July), 69-80.

1993 "Ubicando la literatura afroecuatoriana en el contexto nacional: ¿Ilusión o realidad?," Afro Hispanic Review (Spring), 4247.

Herskovitz, Melville

1941 The Myth of the Negro Past. New York: Harper and Brothers $\mathrm{Pu}-$ blishers.

Hidalgo Alzamora, Laura

1982 Décimas esmeraldeñas (Recopilación y análisis socio-literario). Quito: Banco Central del Ecuador.

Hutchinson, George

1995 The Harlem Renaissance in Black and White. Cambridge: Harvard University Press.

1970 Introducción a la cultura africana en América Latina. París: UNESCO. 
Iser, Wolfgang

1978

The Act of Reading: A Theory of Aesthetic Response. Baltimore: The Johns Hopkins University Press.

Iturralde, Diego

1995 "Nacionalidades indígenas y estado nacional en Ecuador," en Enrique Ayala Mora, ed. Nueva historia del Ecuador, tomo 13. Quito: Corporación Editora Nacional y Editorial Grijalbo Ecuatoriana, (pp. 9-58).

Jackson, Richard L.

1988 Black Literature and Humanism in Latin America. Athens: University of Georgia Press.

1979 Black Writers in Latin America. Albuquerque: University of New Mexico Press.

1997 Black Writers and the Hispanic Canon. New York: Twayne Publishers.

1976 The Black Image in Latin American Literature. Albuquerque:

Jauss, Hans Robert University of New Mexico Press.

1982 Aesthetic Experience and Literary Hermeneutics, trans. Michael Shaw. Minneapolis: University of Minnesota Press.

Jehenson, Myriam Yvonne

1995 Latin-American Women Writers (Class, Race, and Gender). Albany: State University of New York Press.

Jurado Noboa, Fernando

1990 Esclavitud en la Costa Pacífica (Iscuandé, Tumaco, Barbacoas y Esmeraldas; Siglos XVI al XIX). Quito: Ediciones Abya-Yala.
Kadir, Djelal

1993 The Other Writing. Postcolonial Essays in Latin America's Writing Culture. West Lafayette: Purdue University Press.

Kirkpatrick, Gwen

1995 "El feminismo en los tiempos del cólera," Revista de Crítica Literaria Latinoamericana, 21, 42 ( $2^{\mathrm{O}}$ semestre $), 45-55$.

Kutzinski, Vera M.

s/f "Afro-Hispanic American Literature," (inédito).

Lara, Jorge Salvador

1995 Breve historia contemporánea del Ecuador. México: Fondo de Cultura Económica.

Leitch, Vincent B.

1992 Cultural Criticism, Literary Theory, Poststructuralism. New York: Columbia University Press.

Lewis, Marvin

1983 Afro-Hispanic Poetry (19401980): From Slavery to "Negritude" in South American Verse. Columbia: University of Missouri Press.

1992 Ethnicity and Identity in Contemporary Afro-Venezuelan Literature. A Cultural Approach. Columbia: University of Missouri Press.

1987 Treading the Ebony Path: Ideology and Violence in Contemporary Afro-Colombian Prose Fiction. Columbia: University of Missouri Press.

Loor Villaquirán, Manuel

1990 "Alonso de Illescas, estratega militar y político," en Rafael Savoia, ed. El negro en la historia: 
Aportes para el conocimiento de las raíces en América Latina. Cayambe: Centro Cultural AfroEcuatoriano.

Luzuriaga, Gerardo

1973 Del realismo al expresionismo: $E l$ teatro de Aguilera Malta. Madrid: Playor, S.A.

Maiguashca, Juan

1992 "La cuestión regional en la historia ecuatoriana (1830-1972)," en Enrique Ayala Mora, ed. Nueva historia del Ecuador, tomo 12. Quito: Corporación Editora Nacional y Editorial Grijalbo Ecuatoriana, (pp. 175-226).

Martillo Monserrate, Jorge

1993 "El poeta les muestra sus raíces (Entrevista con Antonio Preciado)," en Para todos de El Universo (4 abril), 11.

1991 Viajando por pueblos costeños. Guayaquil: Fundación Pedro Vicente Maldonado.

Miller, Christopher

1986 "Theories of Africans: The Question of Literary Anthropology," Critical Inquiry, xiii, 1 (Autumn), 120-139.

Moreno Fraginals, Manuel. Ed.

1977 Africa en América Latina. México: Siglo Veintiuno Editores.

Morner, Magnus. Ed.

$1970 \quad$ Race and Class in Latin America. New York: Columbia University Press.

Morris, Pam

1993 Literature and Feminism. Oxford: Blackwell Publishers.

Morrison, Toni

1992 Playing in the Dark (Whiteness and the Literary Imagination).
Cambridge: Harvard University Press.

NACLA (North American Council on Latin America)

1992 "The Black Americas (14921992),” xxv,4 (February).

Organization of American States

1997 Report on the Situation of $\mathrm{Hu}$ man Rights in Ecuador. Washington, D.C.: Organization of American States.

Ortega, Julio

1988 Crítica de la identidad: La pregunta por el Perú en su literatura. México: Fondo de Cultura Económica.

Ortiz, Adalberto

1968 Juyungo (Historia de un negro, una isla y otros negros). Guayaquil: Editores Librería Cervantes.

1977 "Negritude in Latin American Culture," en Miriam de Costa, ed., Blacks in Hispanic Literature (Critical Essays). New York: Kennikat Press Corporation, 1977.

Ortiz, Fernando

1983 Contrapunteo cubano del tabaco y el azúcar. La Habana: Editorial de Ciencias Sociales.

Pescatello, Ann M. ed.

s/f The African in Latin America. Washington, DC: University Press of America.

Phelan, John Leddy

1967 The Kingdom of Quito in the Seventeenth Century (Bureaucratic Politics in the Spanish Empire). Madison: University of Wisconsin Press. 
Ponce Cevallos, Xavier

1993 "Diversidad cultural en América Latina (Ponencia general)," en 500 años: Historia, actualidad y perspectiva. Coord. María Augusta Vintimilla. Cuenca: Universidad de Cuenca. (231-241)

Proceso de Comunidades Negras del Norte de Esmeraldas

s/f "Algunos de los derechos que los negros nos gustaría tener en la constitución,".

Rabassa, Clementine C.

1981 En torno a Aguilera Malta. Guayaquil: Casa de la Cultura Ecuatoriana.

Rich, Adrienne

1978 "When We Dead Awake," en

Webber, Jeannette y Joan Grumman, eds. Woman as Writer. Boston: Houghton Mifflin.

Richards, Henry J.

1989 La jornada novelística de Nelson Estupiñán Bass: Búsqueda de la perfección. Quito: El Conejo.

Rivera-Rodas, Oscar

1997 "La modernidad y la poética de la vanguardia," en Semiosis (Nueva época), I, 1 (enero-ju- nio), 4-19.

Robles, Humberto

1990 "De la escritura a la oralidad: Fantasía y realidad en José de la Cuadra," Universidad-Verdad, 6 (agosto), 71-82.

1998 "Los monos enloquecidos en el país de las maravillas: paradigma, zonas de contacto, zonas de 'macidez," Kipus, 7.

1992 "Reseña sobre Jorge Icaza, El Chulla Romero y Flores. Ed. Crítica. Coord. Descalzi, Ricardo y Renaud Richard. Madrid: Colección Archivos, 1988," en Revista Iberoamericana, LVIII (abril-junio), 720-725.

1976 Testimonio y tendencia mítica en la obra de José de la Cuadra. Quito: Editorial Casa de la Cultura Ecuatoriana, 1976.

Rout, Jr., Leslie B.

1976 The African Experience in Spanish America. Cambridge: Cambridge University Press.

Salmoral, Manuel Lucena

1994 Sangre sobre piel negra: La esclavitud quiteña en el contexto del reformismo borbónico. Quito: 
Ediciones Abya-Yala.

Samaniego Ponce, Alvaro

1997 "El blanco y negro de un dirigente negro," en El Telégrafo (9 noviembre), 9A.

Sampedro V., Francisco

1990 Atlas histórico-geográfico del Ecuador. Quito: Editcar.

Sánchez Parga, José

1989 "Cultura, sociedad y estado," Ecuador Debate, 18 (septiembre), 13-29.

1986 “Etnia, estado y la 'forma' clase," Ecuador Debate, 12 (diciembre), 25-77.

1989 “¿Quién dijo 'culturas oprimidas’?” Ecuador Debate, 18 (septiembre), 159-182.

Sánchez Parga, José, Fernando Tinajero, Diego Araujo, et al.

1991 Signos de futuro: La cultura ecuatoriana en los 80. Cayambe: Abya-Yala.

Savoia, Rafael. Coord.

1990 El negro en la historia: Aportes para el conocimiento de las raíces en América Latina. Cayambe: Centro Cultural Afro-Ecuatoriano.

1992 El negro en la historia: Raíces africanas en la nacionalidad ecuatoriana. Centro Cultural Afroecuatoriano.

1997 Segundo Encuentro Afro Binacional Colombo-Ecuatoriano. (Las memorias; 30 mayo-1 junio de 1997).

Smart, Ian.

1984 Central American Writers of West Indian Origin. A New Hispanic Literature. Washington, D.C.: Three Continents Press.

1990 Nicolás Guillén: Popular Poet of the Caribbean. Columbia: University of Missouri Press.

Soeiro, Susan A.

1975 "Recent Work on Latin American Women: A Review Essay," Journal of Interamerican Studies, 17, 4 (November), 497-512.

Solaún, Mauricio y Sidney Kronus

1973 Discrimination Without Violence: Miscegenation and Racial Conflict in Latin America. New York: John Wiley and Sons.

Sommers, Joseph

1977 "From the Critical Premise to the Product: Critical Modes and Their Applications to a Chicano Literary Text." New Scholar, 6, 51-80.

1990 The World Factbook. Washington, D.C.: Central Intelligence Agency.

Tinajero, Fernando

1987 De la evasión al desencanto. Quito: Editorial El Conejo. 
154 / Michael Handelsman

Tittler, Johnathan

1984 “Juyungo/Reading Writing," en William Luis, ed. Voices from Under: Black Narrative in Latin America and the Caribbean. Connecticut: Greenwood Press.

Townsend, Camilla

s/f "The Social History of Guayaquil" (inédito).

Varas, Patricia

1993 Narrativa y cultura nacional. Quito: Abrapalabra Editores.

Velasco MacKenzie, Jorge

1986 Tambores para una canción perdida. Quito: Editorial El Conejo.

Wade, Peter

1993 Blackness and Race Mixture: The Dynamics of Racial Identity in Colombia. Baltimore: The Johns Hopkins University Press.

Whitten, Jr, Norman E.

1974 Black Frontiersmen. A South American Case. New York: John Wiley and Sons.

1965 Class, Kinship, and Power in an Ecuadorian Town. The Negroes of San Lorenzo. Stanford University Press. 